\title{
The Effect of Religiosity and Spirituality on Work Practices and Trust Levels in Managers and their Subordinates in Food and Nutrition Care Departments
}

Jennifer S. Oler

Brigham Young University - Provo

Follow this and additional works at: https://scholarsarchive.byu.edu/etd

Part of the Food Science Commons, and the Nutrition Commons

\section{BYU ScholarsArchive Citation}

Oler, Jennifer S., "The Effect of Religiosity and Spirituality on Work Practices and Trust Levels in Managers and their Subordinates in Food and Nutrition Care Departments" (2004). Theses and Dissertations. 556. https://scholarsarchive.byu.edu/etd/556

This Thesis is brought to you for free and open access by BYU ScholarsArchive. It has been accepted for inclusion in Theses and Dissertations by an authorized administrator of BYU ScholarsArchive. For more information, please contact scholarsarchive@byu.edu, ellen_amatangelo@byu.edu. 


\title{
THE EFFECT OF RELIGIOSITY AND SPIRITUALITY ON WORK PRACTICES AND TRUST LEVELS IN MANAGERS AND THEIR SUBORDINATES IN FOOD AND NUTRITION CARE DEPARTMENTS
}

by

Jennifer S. Oler

\begin{abstract}
A thesis submitted to the faculty of
Brigham Young University
\end{abstract}

In partial fulfillment of the requirement for the degree of

Masters of Science

Department of Nutrition, Dietetics, and Food Science

Brigham Young University

August 2004 


\title{
BRIGHAM YOUNG UNIVERSITY
}

\section{GRADUATE COMMITTEE APPROVAL}

\author{
of a thesis submitted by
}

Jennifer S. Oler

This thesis has been read by each member of the following graduate committee and by majority vote has been found to be satisfactory.

Date

Date

Date
Nora K. Nyland, Chair

Lora Beth Brown

Lori Lee Wadsworth 


\section{BRIGHAM YOUNG UNIVERSITY}

As chair of the candidate's graduate committee, I have read the dissertation of Jennifer S. Oler in its final form and have found that (1) its format, citations, and bibliographical style are consistent and acceptable and fulfill university and department style requirements; (2) its illustrative materials including figures, tables, and charts are in place; and (3) the final manuscript is satisfactory to the graduate committee and is ready for submission to the university library.

Date

Accepted for the Department
Nora K. Nyland

Chair, Graduate Committee
Merrill J. Christensen

Graduate Coordinator

Accepted for the College

R. Kent Crookston

Dean, College of Biology and Agriculture 


\begin{abstract}
THE EFFECT OF RELIGIOSITY AND SPIRITUALITY ON WORK PRACTICES AND TRUST LEVELS IN MANAGERS AND THEIR SUBORDINATES IN FOOD AND NUTRITION CARE DEPARTMENTS
\end{abstract}

\author{
Jennifer S. Oler \\ Department of Nutrition, Dietetics, and Food Science \\ Masters of Nutritional Science
}

The purpose of this study was to examine the extent to which religiosity and spirituality affected daily work practices and leader/follower trust levels in foodservice and nutrition directors and their subordinates. A similar 72-item survey questionnaire was developed for both the directors and employees, which was completed by 129 directors and 530 employees. Both questionnaires contained questions on demographics, religious influences on work practices, trust characteristics, and three validated measures of religiosity: 1) worship service attendance (1=Religiosity Score), 2) influence of spiritual beliefs on daily life, and 3$)$ frequency of prayer $(2+3=$ Spirituality Score $)$. Frequency data was gathered for all questions. Analysis of variance (ANOVA) and Pearson's Correlation were used to assess the relationship of directors' and employees' Religiosity and Spirituality Scores compared to their daily work practices and trust levels. Two-sample t-tests evaluated differences in directors' and employees' perceived trust levels toward each other. 
Most directors and employees were women and Caucasian. Most of the directors and employees had earned a Master's degree and bachelor's degree, respectively. The religion most frequently reported was Protestant. Data analysis of the Religiosity and Spirituality Scores and demographics showed some differences in ethnic group, gender, age, and education level, although there was no consistently identified trend.

Well over one-third of directors (40.3\%) and employees (36.3\%) attended worship services at least four times the previous month. The more directors and employees attended worship services, the more likely they were to demonstrate specific spiritual actions and attitudes at work. Generally, religiosity and spirituality did not appear to influence perceived trustworthiness in directors and employees. However, both directors and employees were rated as being highly trustworthy by their counterpart(s). Directors and employees tend to over-rate their own trustworthiness when compared to ratings by the opposite discipline. Degree of religiosity and spirituality did not consistently affect the way directors and employees rated each others' trustworthiness though it was related to how they perceived their own trustworthiness. Directors expected that their employees were more committed to their jobs than they actually were. 


\section{ACKNOWLEDGMENTS}

I want to express my deep appreciation and love for all those that supported and encouraged me in this endeavor. First, special thanks to my advisor and friend Dr. Nora Nyland, for her patience, encouragement, enthusiasm, and belief in my ability throughout the duration of this project. I appreciate the support and encouragement of my committee members, Dr. Lora Beth Brown and Dr. Lori Wadsworth. Thanks also to my dear friend and research "buddy" Anna Sarver, for making a sometimes tedious job fun and memorable. I would not have been here without her.

Thanks to all my friends and family who made me laugh daily helping me to keep things in perspective. I appreciate all their help and words of encouragement. I am grateful to my parents who taught me the importance of education and helped me believe I could accomplish anything. I appreciate their prayers, advice and motivating examples. Most importantly, I am grateful to my Savior who never left me alone in times of need and provided me with the strength and determination to keep going. 



\section{TABLE OF CONTENTS}

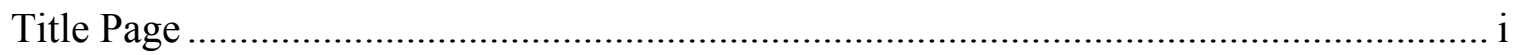

Graduate Committee Approval ................................................................................... ii

Final Reading Approval and Acceptance …………….............................................ii

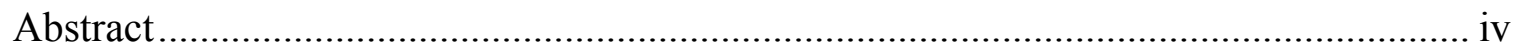

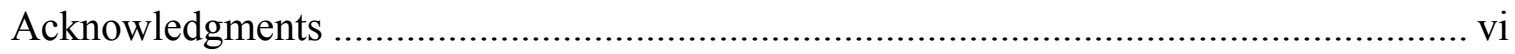

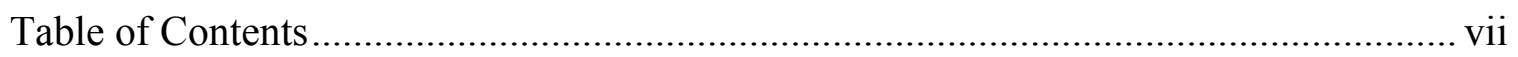

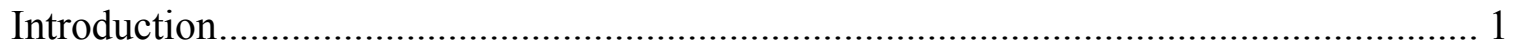

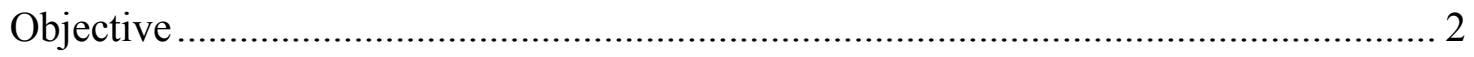

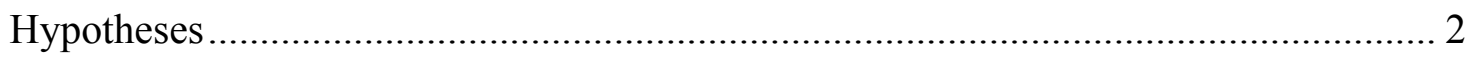

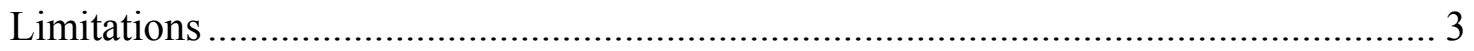

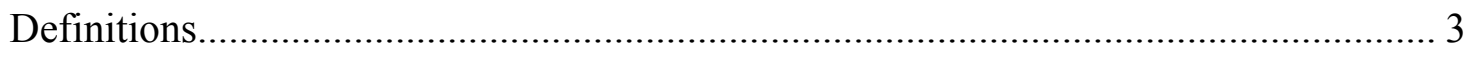

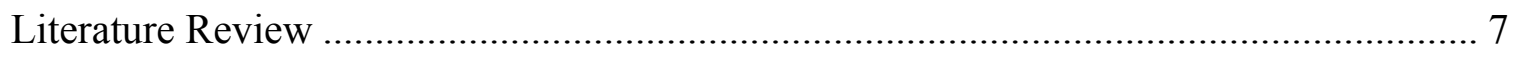

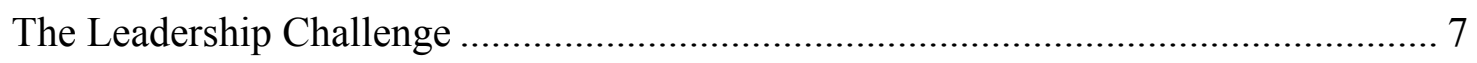

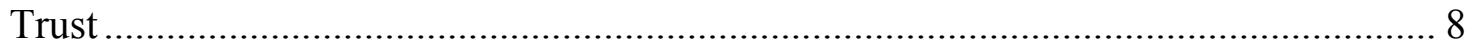

Trust and Management Theories ....................................................................... 8

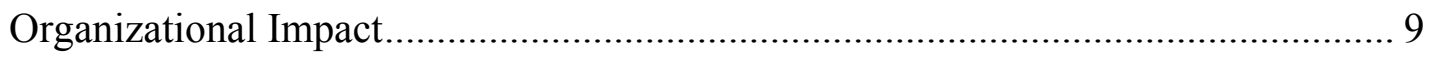

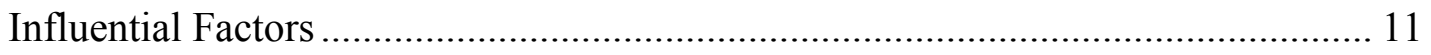

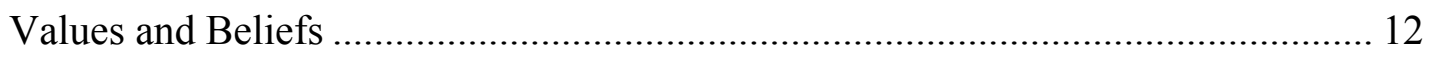

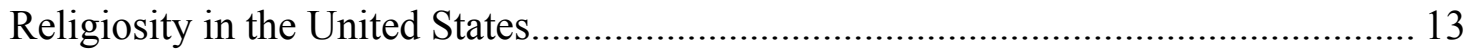

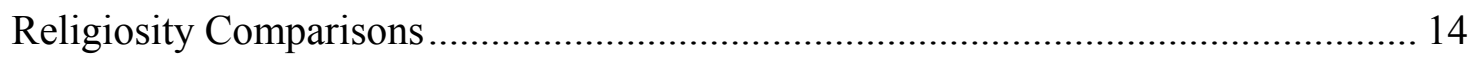

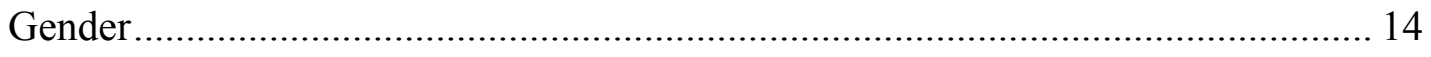

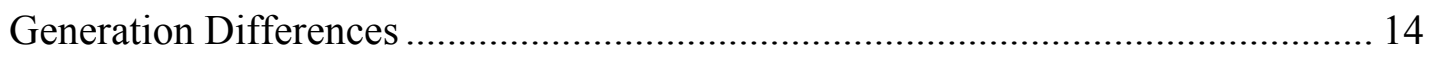




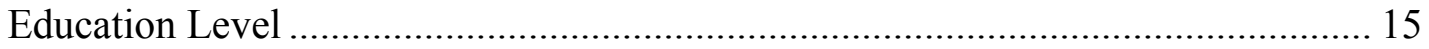

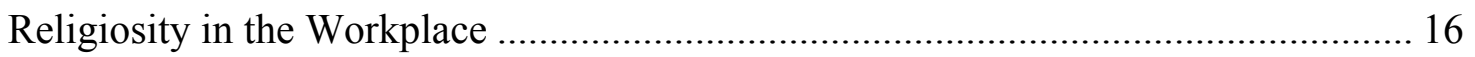

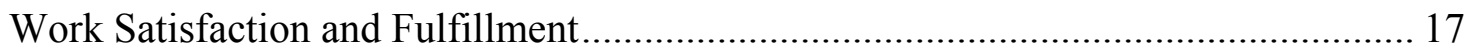

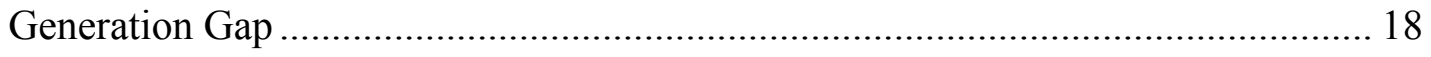

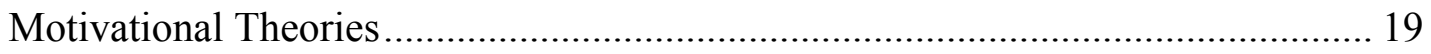

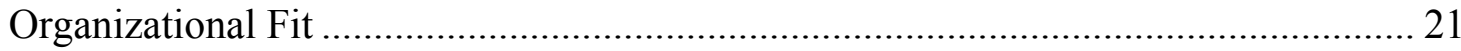

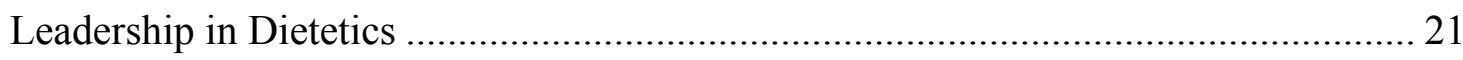

Religiosity/Spirituality in Dietetics.................................................................. 22

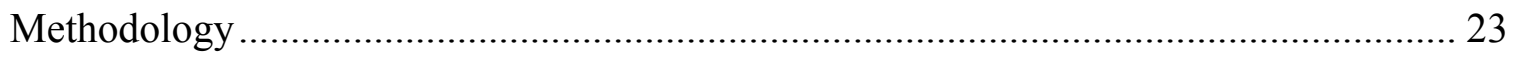

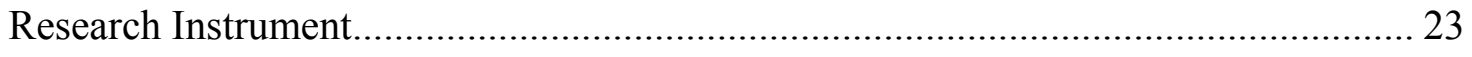

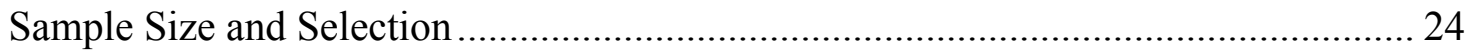

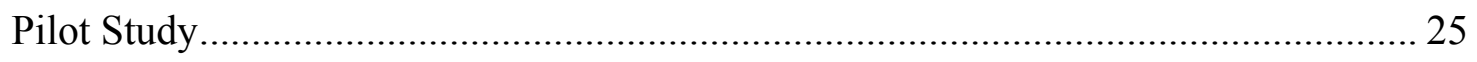

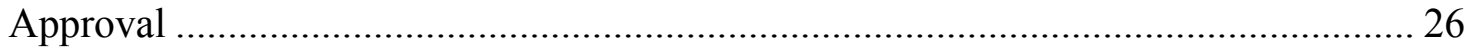

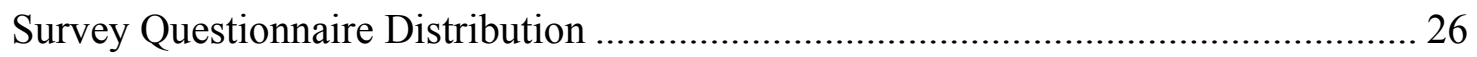

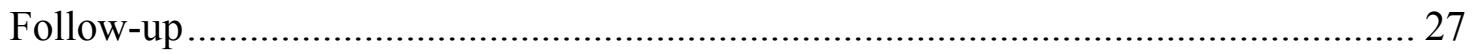

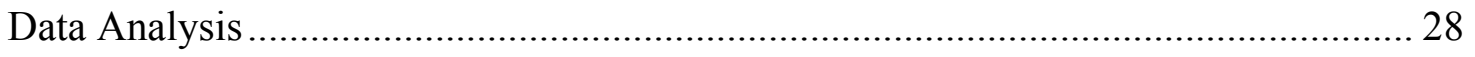

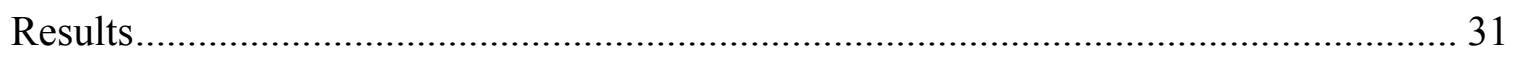

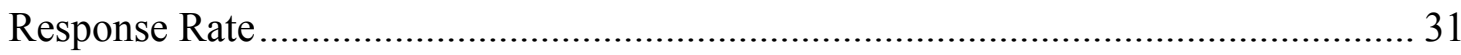

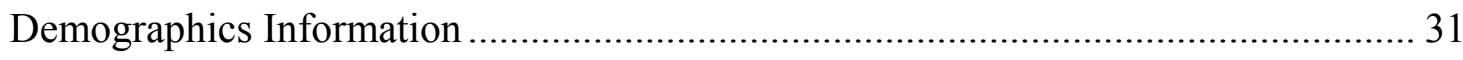

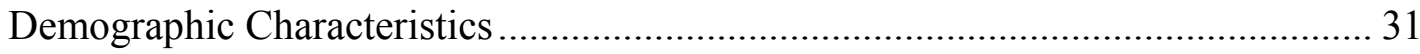

Job Satisfaction and Job Change Consideration .................................................... 35

Time Period in Current Position/In All Management Positions ................................. 36

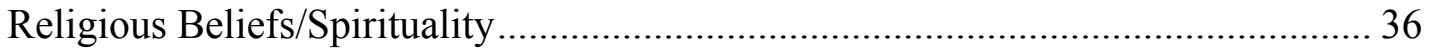


Demographic Characteristics by Religiosity and Spirituality Scores

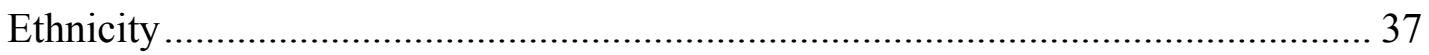

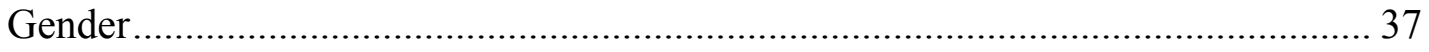

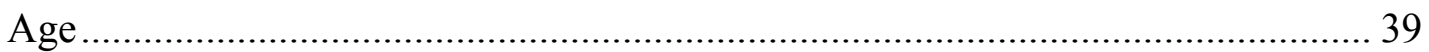

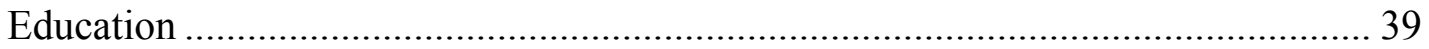

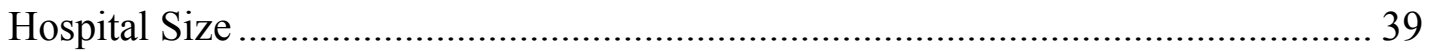

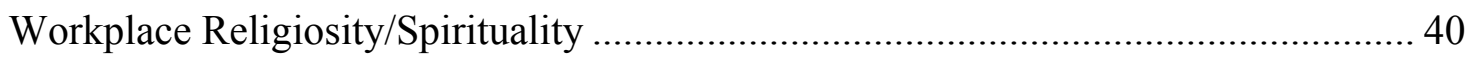

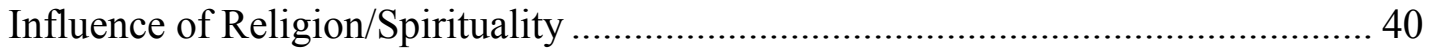

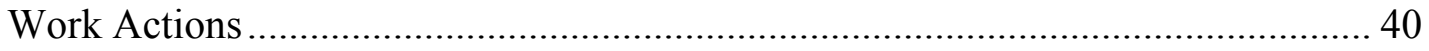

Religiosity and Spirituality Scores Analysis................................................. 42

Religious/Spiritual Influence and Actions ........................................................... 43

Religious/Spiritual Workplace Actions ......................................................... 46

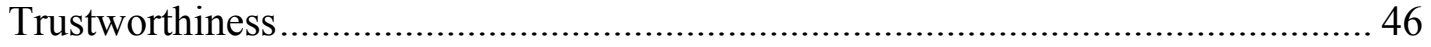

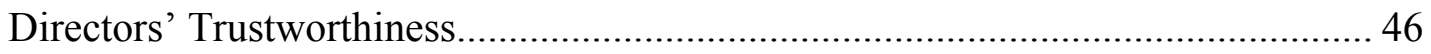

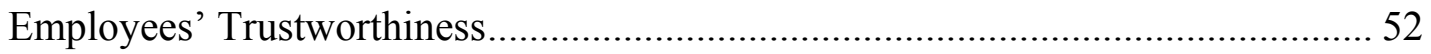

Trust by Religiosity and Spirituality Scores ................................................. 53

Self-Rated Directors' Trust by Directors' Religiosity and Spirituality Scores......... 53

Employee-Rated Directors' Trust by Directors' Religiosity and Spirituality ......... 56

Employee-Rated Directors’ Trust by Employees’ Religiosity and Spirituality........ 57

Self-Rated Employees’ Trust by Employees’ Religiosity and Spirituality Scores... 57

Director-Rated Employees’ Trust by Directors' Religiosity and Spirituality Scores61

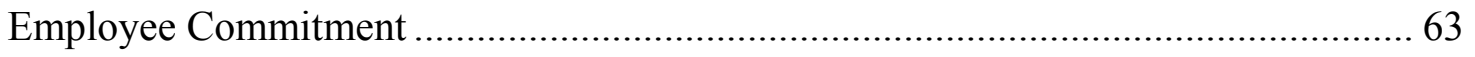

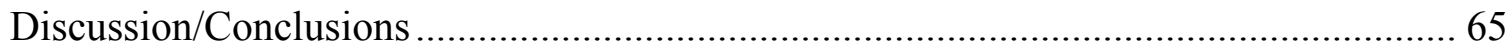




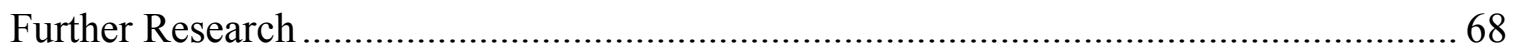

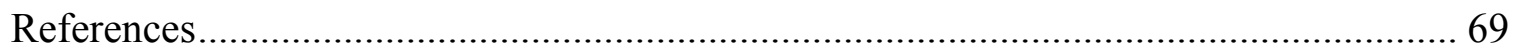

Appendices

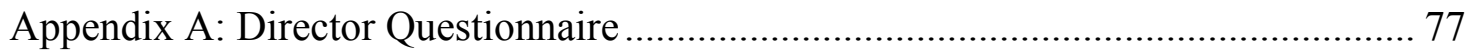

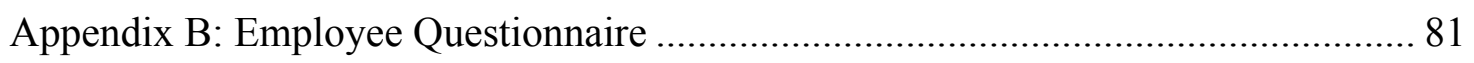

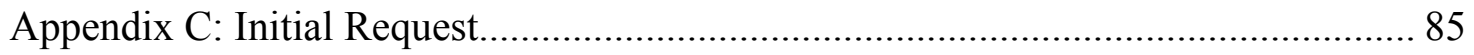

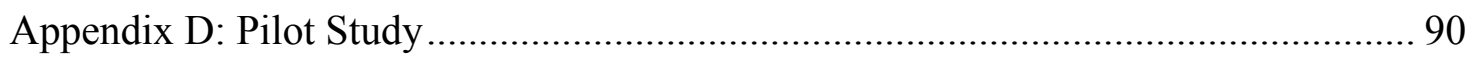

Appendix E: Institutional Review Board Approval.................................................... 95

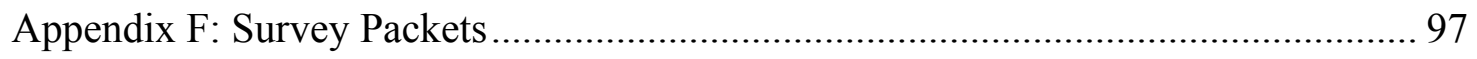

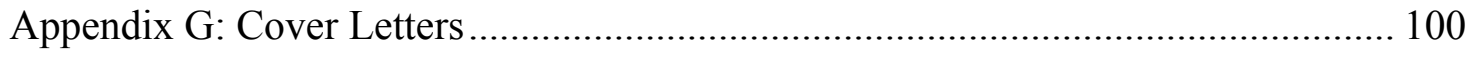

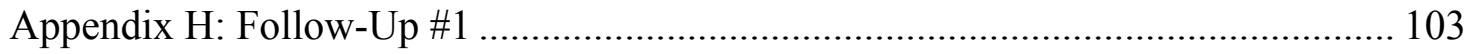

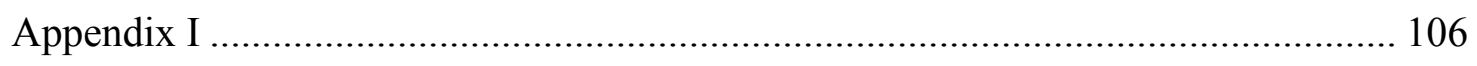

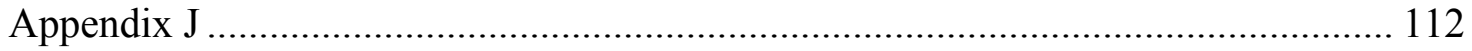

List of Tables

Table 1: Demographic Characteristics of Respondents ............................................. 32

Table 2: Demographics by Religiosity and Spirituality Score....................................... 38

Table 3: Religious Beliefs/Spirituality Influence on Work Practices ........................... 41

Table 4: Religious/Spiritual Actions in the Workplace .............................................. 41

Table 5: Influence of Religious Beliefs/Spirituality by Religiosity Score .................... 44

Table 6: Influence of Religious Beliefs/Spirituality by Spirituality Score ................... 45

Table 7: Spiritual Actions by Religiosity Score ……………………….................... 47

Table 8: Spiritual Actions by Spirituality Score …………......................................... 48 


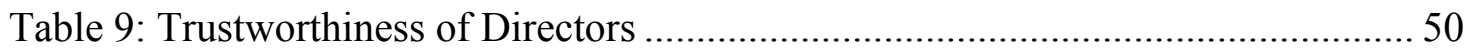

Table 10: Director and Employee Response Differences for Trust Questions .............. 50

Table 11: Trustworthy Actions of Directors ............................................................... 51

Table 12: Trustworthiness of Employees ................................................................. 51

Table 13: Directors’ Trust by Directors' Religiosity Score........................................ 54

Table 14: Directors' Trust by Directors' Spirituality Score …………………….......... 55

Table 15: Employee-Rated Directors' Trust by Employees' Religiosity Score ............ 58

Table 16: Employee-Rated Directors' Trust by Employees Spirituality Score............ 59

Table 17: Self-Rated Employees’ Trust by Employees' Religiosity Score................... 60

Table 18: Self-Rated Employees' Trust by Employees' Spirituality Score ….............. 60

Table 19: Director-Rated Employees’ Trust by Directors' Religiosity Score .............. 62

Table 20: Director-Rated Employees' Trust by Directors' Spirituality Score .............. 62

\section{Exhibits}

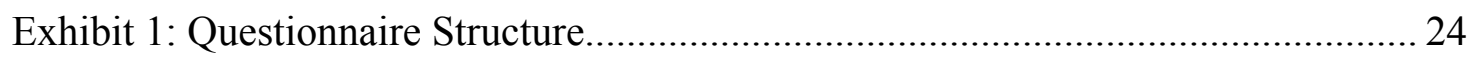

Exhibit 2: Survey Distribution and Follow-Up Outline............................................... 27

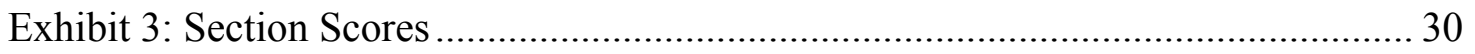




\section{INTRODUCTION}

Leadership is complex, yet fundamental to the success of organizations. To meet the challenges of today's rapidly changing organizations, leaders must recognize that leadership is a relationship between those that seek to lead and those who are willing to follow (1). As with all relationships, trust is essential in building and maintaining strong organizational relationships. Unfortunately, trust has been inhibited in the workplace by the perceived low ethics and moral values of management (2). This lack of, or reduction in, trust brings about increased turnover, reduced commitment, low job satisfaction, and overall poor performance and productivity on the job by employees $(3,4,5)$. However, when trust is present, it positively impacts communications, job satisfaction, organizational commitment, employee performance and productivity and overall profitability $(3,4,6,7)$.

What promotes, initiates, and maintains trust is not precisely known. Trust does appear to be dependent on characteristics such as integrity, competence, openness, vulnerability, reliability, and expectations (8). Researchers continue to investigate what individual traits or actions may further enhance trust development $(4,9,10)$.

Today's changing workforce is another challenge that leaders must confront. Generational differences have changed the way management must lead and motivate employees $(11,12)$. Workers no longer just want a job. They want to be able to realize their full potential and take their whole "soul" to work (13). Workers want more balance between all aspects of their lives (14).

In the past, integrating an individual's most personal life, such as their religiosity or spirituality, with their job has typically been avoided (15). In recent years, however, 
this paradigm is shifting as the importance of religiosity and spirituality grows in the lives of Americans (16). More Americans are attending weekly worship services, prayer meetings, and other spiritual retreats in their private lives, but they are also bringing it to work, as observed by the increased prevalence of spiritual and religious symbols and practices in the workplace $(13,15,17,18)$.

Studies investigating religiosity and spirituality in the workplace are increasing. Skousen (19) surveyed dietitians in management positions and found that they were highly religious and they, too, incorporated their beliefs into their daily work practices. There are no studies that investigate religiosity and spirituality in dietitians in nonmanagement positions. Also, there are no studies known that examine the relationship of religiosity/spirituality and trust in the workplace.

\section{Objective}

To investigate the impact of religiosity and spirituality on work practices and trust levels in foodservice and nutrition directors and those whom they directly supervise.

\section{Hypotheses}

Hypothesis I: Foodservice/nutrition directors and employees that have higher Religiosity and Spirituality Scores will have a higher level of agreement regarding statements of the influence of spirituality on workplace practices.

Hypothesis II: Directors/managers that have higher Religiosity and Spirituality Scores will be perceived by their subordinates as having increased characteristics that promote trust in the workplace. 
Hypothesis III: Foodservice and clinical nutrition employees that have higher Religiosity and Spirituality Scores will be perceived by their directors as having increased characteristics that promote trust and commitment in the workplace.

\section{Limitations}

This study is based on survey responses of directors of hospital food and nutrition care departments and their subordinates. Request for participation was extended to all directors in the study population, however, only those directors willing to participate are represented. Directors were relied upon to invite their employees to participate in the study; therefore, it is difficult to estimate the actual size of the employee population. Also, only participating employee views could be included in this study, so it may not represent the employee population in is entirety.

Although characteristics of trust often described in the literature were used to measure levels of trust, there is not a known validated measure of trust applicable to this study. Therefore, trust scores may not fully measure the trustworthiness of directors and employees.

\section{Definitions}

Religiosity - A measure of "religiousness," determined in a variety of ways including: 1) attendance of worship services, 2) influence of religious/spiritual beliefs on daily life, and 3) frequency of prayer or meditation (20). Webster (21) defines religiousness as relating to or devotion to religious beliefs or observances. For the purpose of this study, 
religiosity will be determined by one of the validated measures, frequency of worship service attendance and will be known as the Religiosity Score. The other two validated measures will be combined as one score and referred to as the Spirituality Score (see definition below)

Religiosity Score - A validated measure of religiosity based on attendance of worship services in the past month. Scores ranged from zero to four $(0=$ no attendance in the past month, $1=$ once, $2=$ twice, $3=$ three times, and $4=$ four or more times).

Spirituality- More difficult to distinguish, there is not a validated way to measure spirituality (20). For this study, spirituality and religiosity will be examined separately, though they are not necessarily independent of each other. Spirituality will be determined by the Spirituality Score (see definition below). Webster (21) defines spirituality as a sensitivity or attachment to religious values, or the quality or state of being spiritual. Webster (21) defines spiritual as that which affects the spirit and relating to sacred matters.

Spirituality Score - This score is based on the results of two validated measures of religiosity (survey questions 71 and 72, see appendix A and B) (20). However because the measures are not affiliated with worship service attendance, they were used to measure spirituality in this study. The first question investigated the influence of religious/spiritual beliefs on daily life. Responses were assigned a number from 0 to 6 ( 0 $=$ strongly disagree to $6=$ strongly agree). Next, frequency of prayer or meditation was 
measured. Responses were assigned a number from zero to five $(0=$ never, $1=$ seldom, $2=\mathrm{a}$ few times a month, $3=$ once or twice a week, $4=$ most days, and $5=$ daily). Scores from both questions were summed to range from [0] lowest spirituality to [11] highest spirituality. The score was further categorized into three levels: low spirituality (summed scores 0-5), moderate spirituality (summed scores 6-8), and high spirituality (summed scores 9-11).

Director(s) - The term used to denote both directors of hospital food and nutrition care departments and hospital clinical nutrition managers.

Employee(s) - Subordinates under the direct supervision of directors of food and nutrition services or clinical nutrition managers. Employees may include, but are not limited to, foodservice supervisors, dietitians, diet technicians, and secretaries. 


\section{LITERATURE REVIEW}

\section{The Leadership Challenge}

In a time of rapid and necessary change, society seeks leadership; however, finding that leadership is a challenge (2). The increase in leadership complexity, dwindling faith in leaders, and lack of commitment both by managers and employees have facilitated the leadership crisis $(2,22)$. Offerman et al (23) suggest that the unethical decisions and actions seen by political and business leaders are being scrutinized and attacked as never before, resulting in a lack of leader credibility. This contributes to negative leader/follower relationships, including the relationship of trust.

In the 1990's, organizations faced drastic changes including downsizing, mergers, restructuring, re-engineering, and global competition (8). These changes severed the ties of loyalty that had previously allowed trusting relationships to form between employees and their employers (8). In a large national survey in 1992, Patterson and Kim (24) found that $68 \%$ of employees did not trust their current manager, and $38 \%$ of managers did not trust their employees. Workers believed that managers' decisions were made with selfinterest in mind rather than the good of the group (24). In a 2002 survey (25), approximately $75 \%$ of participants strongly agreed or agreed that they trusted the management at their workplaces, while $22 \%$ disagreed or strongly disagreed. However, in a similar question $78 \%$ of participants strongly agreed or agreed that there are "few people" they can completely trust. Sixty percent of participants stated they had to "be careful" in trusting most people. 


\section{Trust}

Kouzes et al (1) suggest that trust is fundamental in all human relationships and "without trust one cannot lead." Establishment of trust must begin on the first day of any relationship, and if lost, it is unlikely that it will be restored to its original level (26). Caldwell and Clapham (27) comment that the ability to trust is based on a person's “experiences, interactions, and perceptions of others, organizations and institutions." Although complex, trust is essential in establishing healthy leader/follower relationships. Understanding what trust actually entails is difficult due to multiple, varying

definitions found in the literature. Mayer, et al (10) defined trust as the willingness to be vulnerable to the actions of another based on expectations of that person's performance. Kreitner and Kinicki (28) simply stated that trust is having shared faith in others' “intentions and behaviors." Mishra and Morrissey (6) surveyed managers in both public and private organizations, and found that over $90 \%$ of the managers viewed trust as a faith in others' integrity, character, and ability. They agreed that trust is expressed by showing confidence and support for one another. Finally, Carnevale (29) suggests that "trust is an expression of faith and confidence that a person or an institution will be fair, reliable, ethical, competent, and nonthreatening."

\section{Trust and Management Theories}

For years, management theorists have written about trust in the organization. Ouchi (30), in describing Japan's Theory Z of humanistic management, suggested that trust and productivity "go hand in hand." With trust managers avoid over-supervising, allowing employees to satisfy their higher level needs. Likert (31) commented that the 
success of industrial nations is dependent on leaders' capability of developing trust.

Finally, Maslow (32) described a self-actualized individual as one who trusts others and is trustworthy.

Hart et al (33) theorized a hierarchy of trust needs similar in pattern to Maslow's hierarchy of motivational needs. They defined three dimensions of organizational trust: Openness/Congruity, Shared Values, and Autonomy/Feedback which correspond to Maslow's safety, social, and esteem needs, respectively. The first trust level, Openness/Congruity, refers to the integrity, fairness, and openness of management. It is suggested that employees can not exhibit trusting behavior until they have risen above the safety level, feeling secure and unthreatened. Trust then can be established at the Shared Values level of trust, corresponding to the social needs level. Shared Values refers to the relationship between superior and subordinate, which results from mutual respect and integrated goals. Although trust development begins at the social level, a higher level of trust can be developed as one ascends Maslow's hierarchy. As individuals move toward the esteem level, there is an increased ability to trust and a greater expectation of being trusted. To continue the ascent towards self-actualization, the organization must provide Autonomy/Feedback, the third trust factor. Autonomy/Feedback refers to praise, reinforcement, and independence of the employee.

\section{Organizational Impact}

In a time when trust is sorely needed for organizational transformation, it is unfortunate that these very changes have diminished trust within the work setting (4). Organizations with decreased trust are associated with increased absenteeism, theft, 
conflict, low accountability, low creativity and poor performance $(3,5,24,34,35)$. On the other hand, studies show trust has a significant influence on organizational dynamics such as group unity (36), effective communication $(5,7,37)$, decision-making (6), job satisfaction $(4,36,38)$, organizational commitment $(4,36,38)$, problem solving (39), and overall employee performance and productivity $(4,6,9,10,36,40)$. Trust also has an impact on profitability. Davis et al (3) explored trust between managers and employees in a restaurant setting. Researchers concluded that sales and profits rose in facilities where employees exhibited greater amounts of trust toward their employer. In fact, trust was a significant predictor of both sales and profits while controlling for fixed variables. In the same study, increased trust was positively related to decreased employee turnover rates over time.

Turnover has a negative relationship with organizational commitment. Committed employees are less likely to leave an organization than are less committed employees $(41,42)$. Organizational commitment is identified in two ways. Meyer and Allen (43) define affective commitment as a person's emotional attachment, identification with, and involvement in a specific organization. It is based on a person's desire to be at work (44). Conversely, continuance commitment reflects the individual's perception of the consequences associated with leaving. Employees believe benefits overshadow the costs of leaving and stay because "they need to (43)." Meyer et al (45) studied the correlation between commitment and job performance in first-level food service managers. They concluded that performance ratings by the supervisor increased as affective commitment increased in unit managers, and ratings decreased as continuance 
commitment increased. Laschinger et al (4) indicated that trust in management is an essential component in promoting affective commitment in the organization.

\section{Influential Factors}

Although having good trusting relationships is important, factors that facilitate trust are not universally recognized. For instance, Mayer et al (10) suggest that managers' trust-worthiness is directly related to their ability, benevolence, and integrity. First, the trustor (subordinate) must identify that the trustee (manager) has the ability to complete the task at hand, and, as perceived ability increases, so will trust. Next, the greater the trustor feels the trustee has his/her best interests in mind, the greater the trust. Finally, levels of trust will rise as employees' perception of manager integrity expands. That is, if the employee believes the manager follows a set of principles that the employee agrees with, the employee rewards the manager with trust. Davis et al (3) confirmed that managers perceived to exhibit these trust-promoting characteristics were trusted significantly more by their employees.

Rusaw (9) indicates several variables that influence the perception of trust in the leader/follower relationship, including reliability, the degree of perceived similarity, integrity, competence, consistency, loyalty, and self-disclosure. Self-disclosure is revealing oneself to others through verbal and nonverbal means. Verbal disclosure refers to revealing personal information through normal conversation. Nonverbal disclosure includes an individual's actions, appearance, and the things which surround them at work (music, pictures, etc.). By self-disclosing, a person will share their strongest beliefs, values, and desires with those with whom they associate in the workplace (46). Kouzes 
et al (47) concluded that employees were more likely to trust self-disclosing managers. Misha and Morrissey (6) agree that open communication and the willingness to volunteer personal information about oneself to others will generate trust in organizations.

Being open and willing to share ideas and information about the job freely can also influence trust (9). Laschinger et al (4) conducted a survey of randomly selected staff nurses in Canada and concluded that nurses' perception of access to information and support significantly influenced their trust in management. This ultimately influenced job satisfaction, belief and acceptance of organizational goals, and affective commitment.

\section{Values and Beliefs}

Hosmer (48) suggests that trust is based on an assumption of an unspoken moral duty. However, the perception of management's low ethics and moral values held by American workers has been described as the major cause for the "problems" in the business world (24). Often "ethics" is viewed as a way of behaving that can be enforced by a work environment or a work code of conduct. Each individual has a basic understanding of what is morally appropriate, but Garcia-Zamor (49) suggests it is actually the individual's spirituality that will determine the degree to which he or she will interpret and follow this moral structure. Mertzman and Madsen (50) posit that in organizations that do not foster an ethical climate, deception becomes unavoidable. When an opportunity arises and the risk is minimal dishonesty will occur.

Of greater concern is the effect of unethical values on workplace relationships. Jones and Kavanagh (51) indicate that unethical behavior by managers and co-workers results in decreased ethical behavior by employees. Kantor and Weisberg (52) 
interviewed employees about perceived ethical attitudes and behavior of themselves, peers, and managers in a large finance department. Employees believed they had higher ethical standards and behavior than they perceived their bosses and co-workers to have. In an earlier study (24) nearly $37 \%$ of managers and employees agreed that employees were more ethical than managers. Only $13 \%$ and $19 \%$ of managers and employees, respectively, agreed that managers were more ethical.

\section{Religiosity in the United States}

In the last ten years, polls suggest that the importance of religion in the lives of Americans is increasing, compared to the downward spiral seen in previous decades (16). More Americans are seen participating in weekly religious services, prayer meetings, spiritual revival retreats and so forth $(13,15,16,17,18)$. This renewed surge of interest, whatever the true cause, is expected to continue to increase in the coming years (16).

Gallup Polls (16) in 1999 found that about 44\% of Americans attend church weekly, $96 \%$ believe in God or a universal spirit, and $75 \%$ pray or mediate daily (all of these figures have been stable or increasing over the past 20 years). The 2002 General Social Survey (25) found only $30 \%$ of Americans attend church weekly and $56 \%$ pray daily. These results are lower than those from the Gallup Polls, but also reflect an increase from past years. There are many validated measures of religiosity including frequency of worship service, frequency of prayer and meditation, and daily influence of religious beliefs (20). 


\section{Religiosity Comparisons}

\section{Gender}

Overall women engage in more religious behaviors than men. They attend religious services, pray, and believe in God or a universal spirit more often than do men $(24,53,54,55)$. Studies $(56,57,58)$ also show that women convey a greater interest and are more personally committed to all types of religious organizations or belief systems than are men. Women continue to be the moral fiber of churches today (16).

Many believe that it is the increased nurturing characteristics and opportunity for child rearing that give women the edge in things of a religious and spiritual nature. Certain innate characteristics in women such as submissiveness, passiveness, obedience, and nurturing have been found to be related to increased levels of religiosity $(56,59,60)$.

\section{Generation Differences}

With age, religion appears to become more important to Americans. This trend has been consistent throughout history $(53,54,55,61,62,63)$. When asking Americans the degree to which their religious beliefs influence their daily life, Argue et al (61) found an increase in religiosity with age. One study (53) found that $39 \%$ of adults over the age of 65 attended religious services at least once a week, whereas only $26 \%$ of young adults attended. Greeley (64) suggests that young people distance themselves from their religious roots in their early years of family and career. As they become more settled, they return to them. However, more recent surveys have shown that the millennial generation (those born after 1980) appear to have a greater interest in things of a spiritual nature at an earlier age than did past generations (16). In the late 1980's surveys found 
that $52 \%$ of teens and only $40 \%$ of adults reported attending church $(55,63)$. The latest of the Gallup polls (1999) confirms this increase in religiosity/spirituality in teens: $95 \%$ "say they believe in God," 74\% "pray when alone," and 64\% "have a great deal of interest in discussing the existence of God." In general, teens are more service oriented than in the past, they discuss spiritual matters more frequently, and they desire clarification on ethical rules (16).

\section{Education Level}

Much of the literature suggests that increased education has a negative influence on religious commitment $(65,66,67,68)$. Wadsworth and Freeman $(67)$ investigated the change in religious belief from childhood to adulthood in an English, Welsh, and Scottish population. They concluded that change in religious belief was strongly associated with the population's educational achievements. Advanced levels of education were associated with a decrease in belief. Approximately half of those receiving university degrees still retained their childhood belief system. Similarly, Caplovitz and Sherrow (65) found there was an increased probability of apostasy in those that participated in higher education. The researchers suggested that commitment to intellectual pursuits weakened religious commitment because of the exposure to new ideas and separation from family influence. Conversely, Greeley and Zelan $(69,70)$ argue that a person seeks higher levels of education because they have already rejected their religious beliefs.

Within denominations this trend is not consistent. Merrill et al (71) studied Mormons and indicated that education had a positive influence on religiosity in both Mormon men and women, rather than the expected secularizing influence. Loury (72) 
investigated church attendance among high school aged (14-17 years) American youth (mixed denominations) and concluded that church attendance increases the likelihood that an individual will finish high school and attend college.

\section{Religiosity in the Workplace}

As with the growth of spirituality in American's private lives, religious/spiritual changes have been seen in the workplace and are gaining attention in both trade publications and research journals. Religious and spiritual symbols and practices are growing more prevalent and acceptable in the workplace as seen by the increase in enrichment and empowerment programs, prayer meetings, Bible study, religious/spiritual language, and requests for time off for religious obligations or holidays $(13,15,16,17$, $18,49)$. In the 1990's alone over 300 publications on workplace spirituality appeared in bookstores (49). Business periodicals and journals contain a growing number of articles about the restored religious fervor and rising spirituality in the workplace and society (73).

Bruce (74) surveyed members of the American Society for Public Administration (ASPA) regarding their views about spirituality in the workplace and found that $70 \%$ of members defined themselves as spiritual. Nearly $60 \%$ of respondents felt that their career choice, that of public service, was a spiritual calling. Fifty-six percent, though, did not believe it was "appropriate to talk about spirituality" in the workplace. However, in the recent Gallup Poll (16) 48\% of Americans stated that in the past 24 hours they had talked about their faith in the workplace. 
Mitroff and Denton (13) initiated an empirical study of spirituality in the workplace through interviews and questionnaires administered to top executives from businesses across the country. This was one of the first studies that examined religiosity and spirituality in the workplace to provide both quantitative and qualitative data. Nearly all participants believed in a higher power or God, and half agreed they felt that power while at work. On the other hand, executives rarely prayed or meditated in the workplace.

Most interesting to note, the researchers learned that workers no longer just want a job. Executives stated that being able to realize their full potential was most important to them. They wanted to be able to express their "total feelings" and "complete soul" at work as they did their "total intelligence," however most were cautious to do so. This separation seen between intellect and emotions in workplaces allows little opportunity for workers to realize their full potential (13).

\section{Work Satisfaction and Fulfillment}

As employees seek for meaning at work, leaders search for new ways to encourage and motivate workers. Businesses are realizing that employee fulfillment helps to raise productivity and job satisfaction and thus it is important for financial success (49). When spiritual people join a workplace that fits their needs, they are more supportive of their colleagues and become more productive employees. Personal fulfillment and maintaining high ethics are related to outstanding performance (49).

Management is complicated further by changing workplace demographics.

Ethnic, racial, gender, and age diversity are now commonplace $(75,76)$. What promotes 
job satisfaction and fulfillment differs by demographic, especially in diverse age groups $(11,14,76)$

\section{Generation Gap}

Today's workforce can be divided into three diverse generational groups: 1) Baby Boomers, born between years 1945-1964; 2) Generation X (Xers), born from 1965-1980; and 3) Generation Y (Millennial Generation) born after 1980. Major differences are found between employee work values, attitudes, and expectations of the Baby Boomers and the Xers. Generation Y is just beginning to enter the workforce and differences are just beginning to emerge (76).

Baby boomers tend to be hard working and more loyal to their employer than Xers. They expect their managers to give direction and lead them towards organizational goals, and they accept that direction. However, they do not typically like change. In contrast, Xers focus more on personal satisfaction rather than just on hard work $(11,76)$. Keaveney (14) comments that Xers "want balance in their lives, demanding time for work, play, family, friends, and spirituality." They are loyal to their profession and not necessarily to their employer (11). They want flexibility in their lifestyles and jobs (12, $14,77)$.

Generation Xers need their jobs to collectively provide self-achievement along with lifes' basic needs. They do not want work to negatively impact their quality of life (76). Tulgan (12) suggests that job satisfaction is more important to Xers than promotion because they focus on life outside of work. They might accept a less desirable position or 
promotion if it matches their lifestyle. They are not willing to make sacrifices for their jobs as the Baby Boomers have.

\section{Motivational Theories}

Over the years, a number of motivational models have emerged providing suggestions for promoting motivation in the workplace (46). Similar to recent studies, some theorists suggest that workers desire to achieve their "full potential" which then leads to motivation and job satisfaction.

Need Hierarchy. Maslow (78) proposed a model of human motivation based on an individual's desire to satisfy his/her needs. Maslow described human needs in an ascending hierarchy from lowest-level needs to highest-level needs. As each lower level need is satisfied, the individual is motivated to work to satisfy the next level up. Human needs are categorized as follows:

Physiological needs: survival needs, air, water, food, and shelter.

Safety needs: protection against danger, freedom from fear, security.

Social needs: love, belonging, affiliation, acceptance.

Esteem needs: achievement, recognition, and status, positive self-esteem.

Self-actualization: self-fulfillment, personal growth and development.

Self actualization is the process of growth or discovery of the true self and attaining highest abilities possible (79). Generally, a person seeks to fulfill his basic needs. Once these needs are satisfied the individual is "primarily motivated by his need to develop and 
actualize his fullest potentialities and capacities" or in other words, the individual is motivated by a desire for self-actualization $(32,79)$.

Herzberg's Motivation-Hygiene Theory. Herzberg (80) also studied motivation and suggested that there are two types of factors: those that create job satisfaction (motivation factors) and those that promote dissatisfaction (hygiene factors). Similar to the lower levels of Maslow's hierarchy, the hygiene factors included salary, relationships with coworkers, supervision, and working conditions. Motivating factors included achievement, recognition, work itself, responsibility, and advancement. Herzberg (80) concluded that the lack of the hygiene factors led to job dissatisfaction because of the "need to avoid unpleasantness." Motivating factors produced job satisfaction because of the "need for growth or self-actualization."

Expectancy Theories. According to Vroom (81) and Porter and Lawler (82), people are motivated to work when they expect their efforts to result in valued rewards. An individual expects that his/her efforts will result in improved performance and this improved performance will lead to desirable rewards. Motivation leads to actions when a person expects to actually receive a reward and when those rewards or outcomes are perceived as being important to each person, individually. This motivational force is increased when greater value is placed on the reward and when there are increased expectations that efforts will be successful and rewarded. Key to these theories is the need to achieve a motivational climate that considers the individual's goals and values, or what is most important to the individual (46). 


\section{Organizational Fit}

The work environment includes those specific conditions and circumstances that accompany a particular place of employment. A healthy work environment is a place where workers can feel safe, yet challenged and motivated to be creative. There is trust and open communication between staff members and management. A healthy work environment allows for balance between work and personal life. Diversity is embraced and new ideas are encouraged and supported (83).

Individuals typically select and prefer to work for organizations that they perceive best fit their own characteristics (84). Poor person-organization fit results in greater possibility of turnover and poor performance $(85,86,87,88,89)$. An employee who does not fit with his/her current organization may choose to leave (90). O'Reilly et al (88) concluded that person-organization fit does predict turnover intentions significantly. An organization that can decrease voluntary employee turnover can then reduce costs, improve productivity, and, in turn, improve profitability $(3,91)$.

Sims and Kroeck (44) proposed that employees selected working environments that matched their ethical preferences. This correlation was supported in their study; results noted that as length of tenure increased there was less difference in preferred and described work climate, suggesting employees did not stay with organizations that did not fit their ethical preferences.

\section{Leadership in Dietetics}

The dietetic profession is not immune to the rapid changes seen in the business world. Rising healthcare costs require hospitals and healthcare facilities to focus more on 
financial growth and security. Healthcare advances have decreased hospital length of stay, placing even greater pressure on financial well-being of the healthcare community. These challenges have produced ethical dilemmas for healthcare providers and the nation as a whole (2). As in other organizations, strong leadership will be required to maintain the strength and integrity of the profession while decreasing disloyalty, dissatisfaction, and poor productivity among staff. Barker et al (2) suggest that innovative leadership and empowerment of workers will make these changes positive.

\section{Religiosity/Spirituality in Dietetics}

There is only one study known that looks at the religiosity of dietitians. Skousen (19) surveyed dietitians in management positions and found that almost half (48\%) had attended worship services at least four times the previous month. Further results showed that $70 \%$ of participants agreed that they prayed about work-related issues, and nearly $69 \%$ responded that they had spiritual/religious feelings at work. This study only used frequency of church or worship service attendance to measure religiosity/spirituality. No known studies have looked at the religiosity/spirituality of dietitians in non-management positions. Also, there are no known studies that have investigated the perception of trust held by directors for their employees and/or employees for their directors relative to their individual religiosity/spirituality. 


\section{METHODOLOGY}

\section{Research Instrument}

The research instrument consisted of two individual survey questionnaires: Survey A for directors/managers (Appendix A) and Survey B for direct subordinates (Appendix B). Both surveys contained 72 questions divided into six sections labeled A through F. Section titles and corresponding question numbers are listed in Exhibit 1.

All questions in sections A through D were based on a seven-point scale from [1] strongly disagree to [7] strongly agree. Section A addressed the influence of religiosity and spirituality on workplace practices. Section B solicited information on religious and spiritual actions in the work place. Section C contained questions to determine the level of trust managers thought their employees had for them (Survey A), or the amount of trust employees had for their manager (Survey B). Similarly, Section D asked questions exploring managers trust for their employees, generally (Survey A), or the amount of trust employees thought their managers had for them (Survey B). Questions on Sections A and B and partially Section C were taken from the Skousen (19) religiosity/spirituality survey. Additional questions in Section C were developed to explore other aspects of trust.

Section E is the Multifactor Leadership Questionnaire Form 5X-Short (92). This portion was included in the survey for concurrent research measuring transformational leadership. However, only a few of these questions addressed aspects of trust and are included in the analysis (Questions 30, 41, 42, 44, 46, 57). Questions are based on a fivepoint scale from [0] not at all to [4] frequently, if not always. 
Finally, Section F asked for demographic information. Also included in this section were the three measures of religiosity (20) (Questions 69: worship service attendance, 71: spiritual influence on daily life, and 72: frequency of prayer), general job satisfaction questions (Questions 65: level of satisfaction and 68 on employee survey only: consideration of job change), and length of tenure (Questions 66: time in current position and 67: total time in all management positions or time with current manager).

Exhibit 1. Questionnaire Structure

\begin{tabular}{ll}
\hline Section Title & Questions \\
\hline A. Influence of Spirituality & $\# 1-11$ \\
B. Religious/Spiritual Actions & $\# 12-15$ \\
C. Manager's Trustworthiness & $\# 16-19$ \\
D. Employee's Trustworthiness & $\# 20-25$ \\
F. Multifactor Leadership Questionnaire & $\# 26-57$ \\
$\quad$ Questions used in analysis: & $30,41,42,44,46$ \\
G. Demographics & $\# 58-72$ \\
\hline
\end{tabular}

\section{Sample Size and Selection}

The study population consisted of directors/managers of hospital food and nutrition services and their direct subordinates. An initial request for participation was sent to all 918 hospitals acquired from the American Hospital Association database for all hospitals in the United States having 250-499 beds. More specifically the population included: 
- Directors of food and nutrition services and those under their direct supervision [i.e. foodservice managers/supervisors, dietitians, diet technicians, secretaries (who do not report to a clinical nutrition manager)] and,

- Clinical nutrition managers, where applicable, and those whom they directly supervise (i.e. dietitians, diet technicians, and secretaries).

Specific names of directors were not available through the database, so the mailing was addressed to the director of food and nutrition services at each hospital. This mailing included an explanatory letter and a return postcard for the director of food and nutrition services and a separate letter and postcard for the clinical nutrition manager (Appendix C). Directors of food and nutrition services were asked to forward the clinical nutrition manager's letter and postcard where applicable. Those directors/managers that agreed to participate completed and returned the postage paid postcard(s). Returned postcards provided contact information and the number of direct subordinates supervised by each director/manager.

\section{Pilot Study}

Three of the 918 hospitals were randomly chosen to test the research instruments and procedures. Directors were contacted beforehand to ensure willingness to participate. The director and their direct subordinates at each facility received:

- A pilot cover letter (Appendix D)

- A pilot response questionnaire (Appendix D)

- Samples of:

- Initial request letters 
- Postcards

- Survey cover letters

- Surveys

Eleven pilot questionnaires and surveys were returned from managers and subordinates from the three hospitals. Respondents' suggestions were reviewed and appropriate changes made.

\section{Approval}

The research methodology and instrument were approved by Brigham Young University's Institutional Review Board for Human Subjects (Appendix E).

\section{Survey Questionnaire Distribution}

Survey packets were sent to each director/manager that agreed to participate. The packets included:

- Instruction letter explaining the surveys and distribution procedures (Appendix F)

- One director/manager survey (Appendix A)

- Employee surveys (Appendix B)

- Cover letters (Appendix G)

- Individual postage paid envelopes for return of each survey

Exhibit 2 provides an outline of distribution and follow-up procedures, and which forms and letters participants received. 
Exhibit 2: Survey Distribution and Follow-up Outline

\begin{tabular}{|c|c|c|c|c|}
\hline Mailings & $\begin{array}{c}\text { Foodservice } \\
\text { Director }\end{array}$ & $\begin{array}{l}\text { Foodservice } \\
\text { Subordinates }\end{array}$ & $\begin{array}{c}\text { Clinical } \\
\text { Nutrition } \\
\text { Manager }\end{array}$ & $\begin{array}{c}\text { Clinical } \\
\text { Subordinates }\end{array}$ \\
\hline \multicolumn{5}{|l|}{ Initial Request } \\
\hline Explanatory Letter & $\mathrm{x}$ & & $\mathrm{x}$ & \\
\hline Return Postcards & $\mathrm{x}$ & & $\mathrm{x}$ & \\
\hline \multicolumn{5}{|l|}{ Survey Packets } \\
\hline Instruction Letter & $\mathrm{x}$ & & $\mathrm{x}$ & \\
\hline Survey Cover Letter & $\mathrm{x}$ & $\mathrm{x}$ & $\mathrm{x}$ & $\mathrm{x}$ \\
\hline Survey Questionnaire & $\mathrm{x}$ & $\mathrm{x}$ & $\mathrm{x}$ & $\mathrm{x}$ \\
\hline Postage Paid Envelopes & $\mathrm{x}$ & $\mathrm{x}$ & $\mathrm{x}$ & $\mathrm{x}$ \\
\hline \multicolumn{5}{|l|}{ Follow-up Email/Letters } \\
\hline Follow-up 1 & $\mathrm{x}$ & & $\mathrm{x}$ & \\
\hline Follow-up 2 & $\mathrm{x}$ & $\mathrm{x}$ & $\mathrm{x}$ & $\mathrm{x}$ \\
\hline Follow-up 3 & $\mathrm{x}$ & & $\mathrm{x}$ & \\
\hline
\end{tabular}

\section{Follow-up}

Approximately four to five weeks following the packets being mailed, the first follow-up email/letter was sent to each director/manager (Appendix H). Form A was sent to director/managers who had already returned their director/manager survey and form B was sent to all other directors/managers. A second follow-up was sent four weeks later. The follow-up was directed at facilities that were placed in one of three groups, and the follow-ups consisted of letters, emails and/or memos to the directors and often to their direct subordinates. The group breakdown is as follows:

- Group 1: Returned director/manager survey, no returned employee surveys

- Sent letter and email for the director and separate letter for employees (Appendix Ia) 
- Group 2: no director/manager survey returned, at least one employee survey returned

- Sent letter and email for the director and separate letter for employees (Appendix Ib)

- Group 3: no return of director/manager or employee surveys

- Emailed memo reminder to the directors

A third and final follow-up letter was sent to those facilities that had returned employee surveys, but had still not returned the director/manager survey (Appendix J).

Surveys were printed and folded by Brigham Young University Print Services. Researchers coded, labeled, assembled, and tracked all initial and follow-up mailings of the survey. Of the 915 (omitting the three that were part of the pilot study) hospital names and addresses received from the American Hospital Association, 178 directors/managers (from 129 facilities) returned postcards agreeing to participate. Surveys were sent to 178 directors/managers; 1763 employee surveys were sent to the directors to be distributed to the employees.

\section{Data Analysis}

Statistics were analyzed using SAS software (version 8.2). Frequency data was obtained for all survey questions for both directors/managers and employees. Religiosity and spirituality were analyzed by computing two distinct scores based on the three validated measures of religiosity (questions 69, 71, 72). First, the Religiosity Score, used independently, was based on the following question [69]: "In the past month, how many times have you attended worship services?" Responses were assigned a number from 
zero to four $(0=$ no attendance in the past month, $1=$ once, $2=$ twice, $3=$ three times, and $4=$ four or more times). The second score, identified as the Spirituality Score, was analyzed by adding the answer codes together from questions 71 and 72 . Question 71 reads: "My religious/spiritual beliefs influence my daily life." Responses were assigned a number from [0] strongly disagree to [6] strongly agree. Question 72 reads: "How often do you pray or meditate?" Responses were assigned a number from zero to five (0 $=$ never, $1=$ seldom, $2=$ a few times a month, $3=$ once or twice a week, $4=$ most days, and $5=$ daily). Summed scores ranged from [0] lowest spirituality to [11] highest spirituality. This score was further categorized into three groups: low spirituality (summed scores 0-5), moderate spirituality (summed scores 6-8), and high spirituality (summed scores 9-11).

Analysis of variance (ANOVA) was used to assess the relationship between Religiosity and Spirituality Scores and specific spiritual influences, actions and trust of managers and employees. ANOVA was performed on each individual question separately and on combined section scores. Section scores were obtained by adding the answer codes of the questions in each section and are referred to as: Spirituality Influence Score (SIS: Section A), Spiritual Actions Score (SAS: Section B), Director Trust Score (DTS: Section C), and Employee Trust Score (ETS: Section D). The breakdown of section scores and corresponding questions are listed in Exhibit 3.

Both the Religiosity and Spirituality Scores were compared to each combined section score and to nearly all survey questions, individually (some of the demographic questions were not included). Pearson's Correlation coefficient was run on the 
Religiosity and Spirituality Scores comparing SIS and SAS. Respondents who skipped any of the questions measuring religiosity/spirituality were not included in the analysis.

Exhibit 3: Section Scores

\begin{tabular}{l|l|l}
\hline \multicolumn{1}{c|}{$\begin{array}{c}\text { Survey Section } \\
\text { (See Appendices A and B) }\end{array}$} & \multicolumn{1}{|c}{$\begin{array}{c}\text { Section Combined } \\
\text { Score Name }\end{array}$} & \multicolumn{1}{c}{ Questions } \\
\hline Section A: & $\begin{array}{l}\text { Spirituality Influences Score } \\
\text { Influence spirituality }\end{array}$ & Questions \#1-11 \\
Section B: & $\begin{array}{l}\text { Spiritual Actions Score } \\
\text { (SAS) }\end{array}$ & Questions \#12-15 \\
Religious/Spiritual Actions & $\begin{array}{l}\text { Director Trust Score } \\
\text { Section C: }\end{array}$ & Questions \#16-19; \\
Directors' Trustworthiness & (DTS) & Questions \#20-25 \\
Section D: & Employee Trust Score & \\
Employees' Trustworthiness & (ETS) & \\
\hline
\end{tabular}

* questions 30, 41, 42, 44, and 46 are from Section E but address manager trustworthiness and are included in with the DTS.

In addition, ANOVA and Pearson's Correlation were used to assess the relationship between the directors' Religiosity and Spirituality Scores and their employees' averaged response of the directors' trustworthiness. Tests were run separately on the individual questions from Section C and Section E (questions 30, 41, 42,44 , and 46) of the employee questionnaire. The employees' responses to these questions were combined to form the DTS. This was then compared to the directors Religiosity and Spirituality Scores. Finally, a two-sample t-test examined the mean differences of the director-rated DTS and the employee-rated DTS and the director-rated ETS and employee-rated ETS. 


\section{RESULTS}

\section{Response Rate}

Of the 915 facilities obtained from the American Hospital Association database, at least 63 were state or federally owned facilities and were not permitted to ask their employees to participate in outside surveys. Of the remaining 852 eligible hospitals of this size, $129(15 \%)$ facilities agreed to participate. From these facilities, surveys were distributed to 178 directors that had agreed to participate; of these, $129(72 \%)$ surveys were returned and considered usable. From the directors' estimate of supervised employees, 1763 employee surveys were sent to directors to be distributed to their employees. Of these, 530 (30\%) employee surveys were returned. However, this may not be a true reflection of the employee response because exact number of employees available and invited to participate is not known.

\section{Demographics Information}

\section{Demographic Characteristics}

Complete demographic characteristics of participants are listed in Table 1. The majority of directors and employees ( $93 \%$ and $80.9 \%$, respectively) were Caucasian. Of the director respondents, 107 (83\%) were women and $22(17 \%)$ were men. There were 473 (90.4\%) female employees and 50 (9.6\%) men. Ages ranged from 21 to over 60 years in both the director and employee samples. The largest number of responding directors were between 41 and 50 years of age (44.5\%). Only nine (7\%) of directors were between 21 to 30 years old. The majority of employees were between the ages of 21 and 50 years (83.3\%). Only $2.7 \%$ of employees were greater than 60 years of age. 
Table 1. Demographic Characteristics of Respondents

\begin{tabular}{|c|c|c|c|c|}
\hline \multirow[b]{2}{*}{ Characteristic } & \multicolumn{2}{|c|}{ Director/Managers } & \multicolumn{2}{|c|}{ Employees } \\
\hline & $\mathbf{n}$ & $\%$ & $\mathbf{n}$ & \\
\hline \multicolumn{5}{|l|}{ Ethnic Group } \\
\hline African American & 2 & 1.6 & 42 & 8.0 \\
\hline Asian and Pacific Islander & 3 & 2.3 & 29 & 5.6 \\
\hline Caucasian & 120 & 93.0 & 419 & 80.9 \\
\hline Hispanic & 2 & 1.6 & 18 & 3.5 \\
\hline Native American & 2 & 1.5 & 6 & 1.2 \\
\hline Other & 0 & 0.0 & 4 & 0.8 \\
\hline \multicolumn{5}{|l|}{ Gender } \\
\hline Female & 107 & 83.0 & 473 & 90.4 \\
\hline Male & 22 & 17.0 & 50 & 9.6 \\
\hline \multicolumn{5}{|l|}{$\overline{\text { Age }}$} \\
\hline $21-30$ & 9 & 7.0 & 153 & 29.3 \\
\hline $31-40$ & 28 & 21.9 & 147 & 28.0 \\
\hline $41-50$ & 57 & 44.5 & 136 & 26.0 \\
\hline $51-60$ & 33 & 25.8 & 73 & 14.0 \\
\hline more than 60 & 1 & 0.8 & 14 & 2.7 \\
\hline \multicolumn{5}{|l|}{ Level of Education } \\
\hline High School Diploma or GED & 1 & 0.8 & 71 & 13.5 \\
\hline Associate degree & 5 & 3.9 & 51 & 9.7 \\
\hline Bachelor's degree & 42 & 32.6 & 220 & 42.0 \\
\hline Master's degree & 60 & 46.5 & 102 & 19.5 \\
\hline Some post grad, but no degree & 19 & 14.7 & 76 & 14.5 \\
\hline Doctoral degree & 2 & 1.5 & 4 & 0.8 \\
\hline \multicolumn{5}{|l|}{ Area of Degree } \\
\hline Business/Management & 12 & 11.5 & 10 & 2.9 \\
\hline Dietetics & 19 & 18.3 & 105 & 30.9 \\
\hline Food Service/Culinary & 4 & 3.9 & 5 & 1.5 \\
\hline Food Science and Nutrition & 10 & 9.6 & 29 & 8.5 \\
\hline Nutrition & 48 & 46.2 & 157 & 46.7 \\
\hline Other & 11 & 10.6 & 30 & 10.0 \\
\hline \multicolumn{5}{|l|}{ Job Title } \\
\hline Clinical Nutrition Manager & 62 & 48.1 & & \\
\hline Director Food and Nutrition & 67 & 51.9 & & \\
\hline Clinical Dietitian & & & 305 & 1.4 \\
\hline Diet Technician & & & 62 & 12.5 \\
\hline Manager & & & 107 & 21.5 \\
\hline Out Patient Dietitian & & & 12 & 2.4 \\
\hline Other & & & 11 & 2.2 \\
\hline \multicolumn{5}{|l|}{ Pay/salary } \\
\hline$\$ 10-19,000 /$ year & 0 & 0.0 & 56 & 11.0 \\
\hline $20-30,000$ & 1 & 0.8 & 127 & 25.2 \\
\hline $31-40,000$ & 2 & 1.6 & 173 & 34.2 \\
\hline $41-50,000$ & 31 & 24.8 & 112 & 22.2 \\
\hline $51-60,000$ & 13 & 10.4 & 16 & 3.2 \\
\hline $61-70,000$ & 30 & 24.0 & 18 & 3.6 \\
\hline more than 70,000 & 48 & 38.4 & 3 & 0.6 \\
\hline \multicolumn{5}{|l|}{ Hours/week } \\
\hline full time & 125 & 97.7 & 411 & 78.9 \\
\hline part time & 3 & 2.3 & 110 & 21.1 \\
\hline
\end{tabular}


Table 1. Demographic Characteristics of Respondents Continued

\begin{tabular}{|c|c|c|c|c|}
\hline \multirow[b]{2}{*}{ Characteristic } & \multicolumn{2}{|c|}{ Director/Managers } & \multicolumn{2}{|c|}{ Employees } \\
\hline & $\mathbf{n}$ & $\%$ & $\mathbf{n}$ & $\%$ \\
\hline \multicolumn{5}{|l|}{ Enjoy Current Job } \\
\hline Strongly agree & 72 & 55.8 & 173 & 33.0 \\
\hline Agree & 45 & 34.9 & 237 & 45.2 \\
\hline Somewhat agree & 11 & 8.5 & 80 & 15.3 \\
\hline Neither agree or disagree & 0 & 0.0 & 13 & 2.5 \\
\hline Somewhat disagree & 1 & 0.8 & 17 & 3.2 \\
\hline Disagree & 0 & 0.0 & 3 & 0.6 \\
\hline Strongly disagree & 0 & 0.0 & 1 & 0.2 \\
\hline \multicolumn{5}{|l|}{ Considering a Job Change } \\
\hline Strongly agree (6) & & & 48 & 9.2 \\
\hline Agree (5) & & & 37 & 7.0 \\
\hline Somewhat agree (4) & & & 79 & 15.1 \\
\hline Neither agree or disagree (3) & & & 105 & 20.0 \\
\hline Somewhat disagree (2) & & & 25 & 4.8 \\
\hline Disagree (1) & & & 131 & 25.0 \\
\hline Strongly disagree $(0)$ & & & 99 & 18.9 \\
\hline \multicolumn{5}{|l|}{ Time in Current Position } \\
\hline less than one year & 14 & 10.9 & 74 & 14.2 \\
\hline 1 to 2 years & 35 & 27.1 & 104 & 19.9 \\
\hline $3-5$ years & 31 & 24.0 & 133 & 25.5 \\
\hline $6-8$ years & 14 & 10.9 & 45 & 8.6 \\
\hline $9-11$ years & 8 & 6.2 & 47 & 9.0 \\
\hline $12-14$ years & 12 & 9.3 & 35 & 6.7 \\
\hline more than 14 years & 15 & 11.6 & 84 & 16.1 \\
\hline \multicolumn{5}{|c|}{ Time in All Management Positions } \\
\hline less than one year & 3 & 2.3 & & \\
\hline 1 to 5 years & 26 & 20.3 & & \\
\hline 6 to 10 years & 14 & 10.9 & & \\
\hline 11 to 20 years & 37 & 28.9 & & \\
\hline more than 20 years & 48 & 37.5 & & \\
\hline \multicolumn{5}{|c|}{ Time Worked with Current Manager } \\
\hline less than one year & & & 99 & 18.9 \\
\hline 1 to 5 years & & & 294 & 56.2 \\
\hline 6 to 10 years & & & 69 & 13.2 \\
\hline 11 to 20 years & & & 45 & 8.6 \\
\hline more than 20 years & & & 16 & 3.1 \\
\hline \multicolumn{5}{|c|}{ Hired from Outside or Within Hospital } \\
\hline Outside Hospital & 66 & 51.2 & & \\
\hline Inside Hospital & 63 & 48.8 & & \\
\hline \multicolumn{5}{|l|}{ Religious Preference } \\
\hline Atheist & 0 & 0.0 & 1 & 0.2 \\
\hline Buddhist & 1 & 0.8 & 6 & 1.2 \\
\hline Catholic & 40 & 31.0 & 158 & 30.5 \\
\hline Christian (Other) & 10 & 7.7 & 38 & 7.4 \\
\hline Hindu & 0 & 0.0 & 1 & 0.2 \\
\hline Jewish & 6 & 4.6 & 14 & 2.7 \\
\hline LDS & 9 & 7.0 & 29 & 5.6 \\
\hline Muslim & 0 & 0.0 & 4 & 0.8 \\
\hline Protestant & 54 & 41.9 & 208 & 40.2 \\
\hline None & 5 & 3.9 & 25 & 4.8 \\
\hline Other & 4 & 3.1 & 33 & 6.4 \\
\hline
\end{tabular}


Table 1. Demographic Characteristics of Respondents Continued

\begin{tabular}{|c|c|c|c|c|}
\hline \multirow[b]{2}{*}{ Characteristic } & \multicolumn{2}{|c|}{ Director/Managers } & \multicolumn{2}{|c|}{ Employees } \\
\hline & $\mathbf{n}$ & $\%$ & $\mathbf{n}$ & $\%$ \\
\hline \multicolumn{5}{|l|}{$\begin{array}{l}\text { Monthly Attendance at Worship Service } \\
\text { (Religiosity Score) }\end{array}$} \\
\hline 0 & 38 & 29.4 & 162 & 31.5 \\
\hline 1 & 13 & 10.1 & 55 & 10.7 \\
\hline 2 & 13 & 10.1 & 61 & 11.8 \\
\hline 3 & 13 & 10.1 & 50 & 9.7 \\
\hline 4 or more & 52 & 40.3 & 187 & 36.3 \\
\hline \multicolumn{5}{|l|}{ Religious/Spiritual Beliefs Influence } \\
\hline Strongly agree & 50 & 39.0 & 221 & 42.3 \\
\hline Agree & 44 & 34.4 & 158 & 30.2 \\
\hline Somewhat agree & 20 & 15.6 & 89 & 17.0 \\
\hline Neither agree or disagree & 6 & 4.7 & 32 & 6.1 \\
\hline Somewhat disagree & 2 & 1.6 & 3 & 0.6 \\
\hline Disagree & 4 & 3.1 & 11 & 2.1 \\
\hline Strongly disagree & 2 & 1.6 & 9 & 1.7 \\
\hline \multicolumn{5}{|l|}{ Frequency of Prayer or Meditation } \\
\hline Daily & 54 & 41.8 & 248 & 47.3 \\
\hline Most days & 32 & 24.8 & 112 & 21.4 \\
\hline Once or twice a week & 17 & 13.2 & 64 & 12.2 \\
\hline A few times a month & 5 & 3.9 & 45 & 8.6 \\
\hline Seldom & 13 & 10.1 & 43 & 8.2 \\
\hline Never & 8 & 6.2 & 12 & 2.3 \\
\hline \multicolumn{5}{|l|}{ Spirituality Score $^{\mathrm{a}}$} \\
\hline Low $(0-5)$ & 16 & 12.6 & 47 & 9.9 \\
\hline Moderate (6-8) & 30 & 23.6 & 86 & 18.2 \\
\hline $\operatorname{High}(8-11)$ & 81 & 63.8 & 341 & 71.9 \\
\hline \multicolumn{5}{|l|}{ Type of Director } \\
\hline Director of Food and Nutrition Services & 66 & 51.2 & & \\
\hline Clinical Nutrition Manager & 63 & 48.8 & & \\
\hline \multicolumn{5}{|l|}{ Type of Employee } \\
\hline Food Service/Managers & & & 198 & 37.4 \\
\hline Clinical Nutrition & & & 332 & 62.6 \\
\hline \multicolumn{5}{|l|}{ Hospital Size } \\
\hline Small $\leq 350$ Beds & 63 & 50.8 & & \\
\hline Large $>350$ Beds & 61 & 49.2 & & \\
\hline
\end{tabular}


The largest group directors (46.5\%) had a master's degree, while the largest group of the employees ( $42 \%)$ had a bachelor's degree. Only one $(0.8 \%)$ director had a high school diploma or GED, while 13.5\% of employees had a high school diploma or GED. Over half of all directors (64.5\%) and employees (77.6\%) obtained their highest degree in Nutrition or Dietetics.

Of the 129 directors, 67 (51.9\%) were the Directors of Food and Nutrition services and 62 (48.1\%) were Clinical Nutrition Managers. Most of the employees (61.4\%) were clinical dietitians, and $12.5 \%$ worked as diet technicians. Just over one fifth (21.5\%) of the employees were in lower level foodservice management positions.

Salary classifications were divided into seven groups. The majority of directors (62.4\%) earned $\$ 61,000$ or more annually while $81.6 \%$ of employees earned between $\$ 20-50,000$ per year. No directors indicated an annual salary of $\$ 10-19,000$. Most of the directors (97.7\%) and employees (78.9\%) reported working full time.

\section{Job Satisfaction and Job Change Consideration}

When asked if they enjoyed their current position, $90.7 \%$ of directors and $78.2 \%$ of employees agreed or strongly agreed that they did. Only $9.2 \%$ of employees strongly agreed when asked if they were considering a job change in the near future. Many employees $(43.9 \%)$ disagreed or strongly disagreed about considering a near future job change (Table 1). 


\section{Time Period in Current Position/In All Management Positions}

Length of time in the respondents' current position varied. Only $10.9 \%$ and $14.2 \%$ of directors and employees, respectively, had been in the position less than a year. Over half $(56.2 \%)$ of employees had worked with their current director for one to five years. Approximately two-fifths (37.5\%) of directors had worked in management positions for over 20 years. When asked how the director was hired to their current position, $51.2 \%$ reported being hired from outside of the hospital and $48.8 \%$ reported being promoted from within the hospital (Table 1).

\section{Religious Beliefs/Spirituality}

Most of the directors were either Protestant (41.9\%) or Catholic (31\%). Similarly, $40.2 \%$ of employees were Protestant and $31 \%$ were Catholic. Few directors $(3.9 \%)$ and employees $(4.8 \%)$ reported having no religious preference (Table 1$)$.

Two-fifths (40\%) of directors reported attending worship services at least four times the previous month, while $29.4 \%$ reported never attending. Similarly, $36.3 \%$ employees reported attending worship services at least four times the previous month and $31.5 \%$ reported no attendance.

When participants were asked if their religious/spiritual beliefs influenced their daily life, $73.4 \%$ of directors agreed or strongly agreed while $72.5 \%$ of employees agreed or strongly agreed that they did. A large number of directors (41.8\%) and employees (47.3\%) reported that they prayed or meditated daily. Almost one-fourth $(24.8 \%)$ of directors/manager and $21.4 \%$ of employees reported praying or meditating most days. 
Only $6.2 \%$ and $2.3 \%$ of directors and employees, respectively, responded that they never prayed or meditated.

Answer codes for questions 71 (religious/spiritual influence on daily life) and 72 (frequency of prayer and mediation) were combined to identify the Spirituality Score. Summed scores were categorized into three groups: low spirituality, moderate spirituality, and high spirituality. The majority of directors (63.8\%) and employees (71.9\%) were classified as being highly spiritual, based on their Spirituality Score.

\section{Demographic Characteristics by Religiosity and Spirituality Scores}

\section{Ethnicity}

There were few differences found in the analysis comparing Religiosity and Spirituality Scores to ethnicity. In both the director and employee populations, the Asian Pacific Islanders had a significantly greater worship service attendance than did the Native Americans in both the director and employee population (Table 2).

\section{Gender}

Although, much of the literature $(53,54,55)$, finds that women are significantly more religious than men, this study found that females had greater Religiosity Scores than men only among the employees. Consistent with Skousen's (19) results, there was no difference in Religiosity Score and gender in directors. There was also no significant difference seen between men's and women's Spirituality Scores for either directors or employees (Table 2). 
Table 2. Demographics by Religiosity and Spirituality Scores

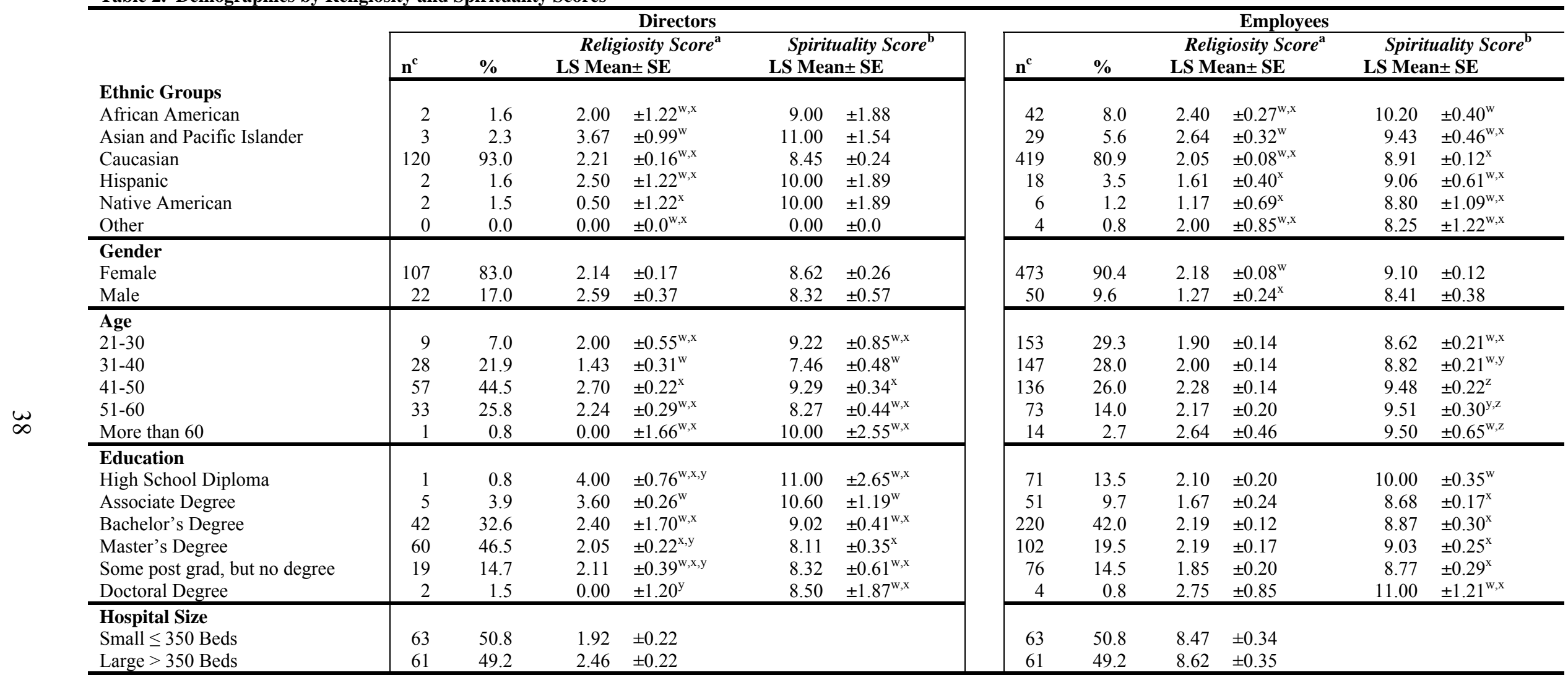

${ }^{\mathrm{a}}$ Religiosity score was given according to attendance of worship service in the past month. Scores ranged from 0-4 (0-no attendance to 4 -four or more times)

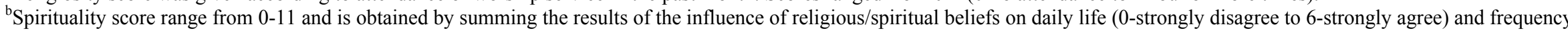
of prayer or meditation (0-never to 5-daily).

${ }^{\mathrm{c}}$ Numbers of subjects differ due to varying response rate.

${ }^{\mathrm{w}, \mathrm{x}, \mathrm{y}}$ LSMeans with different superscript for each characteristic are significantly different from each other, ANOVA P $\leq .05$. 


\section{Age}

Directors aged 41 to 50 years had a higher Religiosity and Spirituality Scores than those directors aged 31 to 40 years. Employees between 41 and 50 years old had a greater Spirituality Score than did employees between both 21 and 30 years and between 31 and 40 years. There was no significant difference seen in employee Religiosity Score by age (Table 2 ).

\section{Education}

Directors with an associate degree did have greater Religiosity and Spirituality Scores than those with a master's degree. Also, directors with an associate degree or a bachelor's degree attended worship services more frequently than did those with doctoral degrees though only two directors held doctoral degrees (Table 2). Education did not appear to have any relationship to employee Religiosity Score. Employees with a high school diploma did have a greater Spirituality Score than did those with an associate, bachelor's, or master's degree (Table 2).

\section{Hospital Size}

Hospitals were distinguished as one of two sizes, large ( $>350$ beds) and small ( $\leq 350$ beds). There was no significant difference seen between directors' Religiosity ( $\mathrm{F}=$ 3.03, $\mathrm{p}=0.08)$ or Spirituality $(\mathrm{F}=0.10, \mathrm{p}=0.75)$ Scores by hospital bed size (Table 2$)$. 


\section{Workplace Religiosity/Spirituality}

\section{Influence of Religion/Spirituality}

When asked to what degree religious beliefs/spirituality influenced daily work practices, directors and employees had a high level of agreement with the majority of the eleven questions (Table 3). However, only $30.71 \%$ of directors and $38.31 \%$ of employees agreed that their religious beliefs/spirituality were a normal part of their discussions with coworkers. Skousen (19) surveyed only dietitians in management positions, and $44.7 \%$ agreed that their religious beliefs/spirituality were a normal part of their discussions as work. Skousen's (19) results, regarding the influence of religious beliefs/spirituality on daily work practices, generally reflected that dietitians in management agreed at a higher level than did directors in this study.

\section{Work Actions}

The majority of directors and employees agreed that they displayed religious/spiritual actions in the workplace (Table 4). Directors and employees $(72.66 \%$ and $69.90 \%$, respectively) claimed to follow God's (a Supreme Being's) example in their interactions, reported having spiritual/religious feelings (directors, 60.94\% and employees, $61.83 \%$ ), and relied on spiritual insight in making decisions at work (directors, 57.03\% and employees, 58.78\%). When directors' responses regarding religious/spiritual actions in the workplace are compared to Skousen's (19) findings, results are generally lower. Skousen (19) reported 76.9\% of managers followed God's (a Supreme Being's) example in their interactions at work, while $68.9 \%$ reported having 
Table 3. Religious Beliefs/Spirituality Influence on Work Practices

\begin{tabular}{|c|c|c|c|c|c|c|}
\hline Director Reponses & \multicolumn{2}{|c|}{ Agree $^{a}$} & \multicolumn{2}{|c|}{ Neutral } & \multicolumn{2}{|c|}{ Disagree } \\
\hline Section A. My religious beliefs/spirituality... & & & & & & \\
\hline help me deal with stressful situations. & 99 & 77.34 & 18 & 14.07 & 11 & 8.59 \\
\hline drive my work ethic. & 99 & 77.34 & 17 & 13.28 & 12 & 9.38 \\
\hline guide my interactions with coworkers. & 98 & 77.17 & 18 & 14.17 & 11 & 8.66 \\
\hline influence my commitment to my job and to my coworkers. & 96 & 75.00 & 15 & 11.72 & 17 & 13.28 \\
\hline guide decisions I make at work. & 93 & 72.66 & 21 & 16.40 & 14 & 10.94 \\
\hline influence my individual goals as a manager. & 92 & 71.87 & 17 & 13.29 & 19 & 14.84 \\
\hline supply me with wisdom/insight in adapting to conditions in the workplace & 91 & 71.09 & 18 & 14.07 & 19 & 14.84 \\
\hline influence how I follow company policies and procedures. & 89 & 69.53 & 20 & 15.63 & 19 & 14.84 \\
\hline are critical in helping me get through each workday. & 82 & 64.06 & 26 & 20.31 & 20 & 15.63 \\
\hline are apparent to those with whom I work. & 77 & 60.16 & 27 & 21.09 & 24 & 18.75 \\
\hline are a normal part of my discussions with coworkers. & 39 & 30.71 & 24 & 18.90 & 64 & 50.39 \\
\hline
\end{tabular}

Employee Responses

Section A. My religious beliefs/spirituality...

help me deal with stressful situations.

drive my work ethic.

guide my interactions with coworkers.

influence my commitment to my job and to my coworkers.

guide decisions I make at work.

influence my individual goals as an employee.

supply me with wisdom/insight in adapting to conditions in the workplace

influence how I follow company policies and procedures.

are critical in helping me get through each workday.

are apparent to those with whom I work.

are a normal part of my discussions with coworkers.

\begin{tabular}{llllll}
\hline & & & & & \\
438 & 83.43 & 41 & 7.81 & 46 & 8.76 \\
408 & 78.46 & 57 & 10.96 & 55 & 10.58 \\
406 & 77.33 & 66 & 12.57 & 53 & 10.10 \\
399 & 76.44 & 64 & 12.26 & 59 & 11.30 \\
390 & 74.57 & 74 & 14.15 & 59 & 11.28 \\
385 & 73.47 & 77 & 14.70 & 62 & 11.83 \\
375 & 72.25 & 82 & 15.80 & 62 & 11.95 \\
380 & 72.80 & 76 & 14.56 & 66 & 12.64 \\
352 & 67.69 & 86 & 16.53 & 82 & 15.77 \\
314 & 60.04 & 126 & 24.09 & 83 & 15.87 \\
200 & 38.31 & 107 & 20.50 & 215 & 41.19 \\
\hline
\end{tabular}

${ }^{a}$ Responses have been collapsed into three categories: (1) Agree ('Strongly Agree, Agree, and Somewhat Agree'), (2) Neutral ('Neither Agree or

Disagree'), and (3) Disagree ('Somewhat Disagree, Disagree, and Strongly Disagree').

Table 4. Religious/Spiritual Actions in the Workplace

\begin{tabular}{|c|c|c|c|c|c|c|}
\hline \multirow[t]{2}{*}{ Director Responses } & \multicolumn{2}{|c|}{ Agree $^{\mathrm{a}}$} & \multicolumn{2}{|c|}{ Neutral } & \multicolumn{2}{|c|}{ Disagree } \\
\hline & $\mathbf{n}$ & $\%$ & $\mathbf{n}$ & $\%$ & $\mathbf{n}$ & $\%$ \\
\hline \multicolumn{7}{|l|}{ Section B. I often... } \\
\hline follow God's (a Supreme Being's) example in my interactions at work. & 93 & 72.66 & 17 & 13.28 & 18 & 14.06 \\
\hline have spiritual/religious feelings at work. & 78 & 60.94 & 15 & 11.72 & 35 & 27.34 \\
\hline rely on spiritual insight in making decisions at work. & 73 & 57.03 & 25 & 19.53 & 30 & 23.44 \\
\hline pray about work-related issues. & 72 & 55.81 & 15 & 11.63 & 42 & 32.56 \\
\hline
\end{tabular}

Employee Responses

Section B. I often...

follow God's (a Supreme Being's) example in my interactions at work.

have spiritual/religious feelings at work.

rely on spiritual insight in making decisions at work.

\begin{tabular}{llllll}
\hline 367 & 69.90 & 87 & 16.58 & 71 & 13.52 \\
324 & 61.83 & 89 & 16.99 & 111 & 21.18 \\
308 & 58.78 & 118 & 22.52 & 98 & 18.70 \\
319 & 60.70 & 66 & 12.57 & 140 & 26.67 \\
\hline
\end{tabular}

pray about work-related issues.

${ }^{a}$ Responses have been collapsed into three categories: (1) Agree ('Strongly Agree, Agree, and Somewhat Agree'), (2) Neutral ('Neither Agree or

Disagree'), and (3) Disagree ('Somewhat Disagree, Disagree, and Strongly Disagree'). 
spiritual/religious feelings at work and $72.3 \%$ relied on spiritual insight in making decisions.

More employees (60.7\%) reported praying about work-related issues than did directors (55.81\%) (Table 4). Again, directors in this study had lower agreement than those in Skousen's (19) study where $70.5 \%$ claimed to pray about work-related issues. Differences seen between this study and Skousen's (19) may be associated with the different management population surveyed. Skousen (19) surveyed only dietitians in a variety of management positions. This included dietitians in food and nutrition services in the hospital setting, but it also included dietitians in community and education management positions. The current study surveyed both dietitians and non-dietitians in hospital food and nutrition management positions only.

\section{Religiosity and Spirituality Scores Analysis}

In the analysis, Least Squares Means (LS Means) were used to equalize the groups because of the large number of terms in the model. LS Means accounts for the whole model with varying sample sizes and adjusts the means correspondingly. Following the ANOVA, significance was considered at a p-value of $<0.05$.

Analysis using Pearson Correlation showed a positive correlation between the Religiosity Score and Spirituality Scores in directors $(\mathrm{R}-\mathrm{Sq}=0.63, \mathrm{p}<0.0001)$ and in employees $(\mathrm{R}-\mathrm{Sq}=0.51, \mathrm{p}<0.0001)$. 


\section{Religious/Spiritual Influence and Actions}

When comparing the influence of Religiosity and Spirituality Scores to work practices (Section A) in directors and employees, analysis showed increasing mean scores (on a scale of $1=$ strongly disagree to $7=$ strongly agree) as Religiosity and Spirituality Scores increased (Tables 5 and 6). Those with higher Religiosity and Spirituality Scores were more likely to agree that their religious beliefs/spirituality influences their commitment, is apparent to those with whom they work, are a normal part of their discussions at work, and are critical in helping them get through the day. Directors and employees with higher Religiosity and Spirituality Scores use their religious beliefs to guide their decisions at work, drive their work ethic, and deal with stressful situations (Table 5 and 6).

Summed scores for the Spiritual Influence Score (SIS) increased as Religiosity and Spirituality Scores increased in both directors and employees (Table 5 and 6). Pearson's Correlation showed a positive correlation between the directors' SIS and their Religiosity (R-Sq=0.55; $\mathrm{p}<0.0001)$ and Spirituality (R-Sq=0.77; $\mathrm{p}<0.0001)$ Scores. Similarly, an increase in employees' Religiosity and Spirituality Scores was correlated (R-Sq $=0.52 ; \mathrm{p}<0.0001$ and $\mathrm{R}-\mathrm{Sq}=0.78 ; \mathrm{p}<0.0001$, respectively) with an increased SIS score. In other words, employees' and directors' level of agreement regarding the influence that their religious and spiritual beliefs have in the workplace increases as their Religiosity and Spirituality Scores increase. 
Table 5. Influence of Religious Beliefs/Spirituality on Work Practices ${ }^{\mathrm{a}}$ by Religiosity Score

\begin{tabular}{|c|c|c|c|c|c|c|c|c|c|c|c|c|c|c|c|}
\hline \multirow{4}{*}{$\begin{array}{l}\text { Table 5a. Director Responses } \\
\text { My religious beliefs/spirituality... } \\
\text { help me deal with stressful situations. }\end{array}$} & \multicolumn{15}{|c|}{ Religiosity Score $^{b}$} \\
\hline & \multirow{2}{*}{\multicolumn{3}{|c|}{$0(n=38)$}} & \multirow{2}{*}{\multicolumn{3}{|c|}{$1(n=13)$}} & \multirow{2}{*}{\multicolumn{3}{|c|}{$\begin{array}{l}2(n=13) \\
\quad \text { LS Mean } \pm \text { SE }\end{array}$}} & \multirow{2}{*}{\multicolumn{2}{|c|}{$3(n=13)$}} & \multirow{2}{*}{\multicolumn{4}{|c|}{$4(n=52)$}} \\
\hline & & & & & & & & & & & & & & & \\
\hline & 4.6 & \pm 0.23 & $2,3,4$ & 5.0 & \pm 0.39 & 4 & 5.8 & \pm 0.39 & 0 & 6.0 & \pm 0.39 & 1 & 6.3 & \pm 0.19 & 0 \\
\hline guide my interactions with coworkers. & 4.3 & \pm 0.22 & $2,3,4$ & 5.0 & \pm 0.36 & 4 & 5.4 & \pm 0.36 & 0,4 & 5.9 & \pm 0.36 & 0 & 6.2 & \pm 0.18 & 0,1 \\
\hline drive my work ethic. & 4.6 & \pm 0.23 & $2,3,4$ & 5.0 & \pm 0.39 & 4 & 5.5 & \pm 0.39 & 0 & 5.8 & \pm 0.39 & 0 & 6.1 & \pm 0.19 & 0 \\
\hline supply me with wisdom/insight. & 4.1 & \pm 0.23 & $2,3,4$ & 4.6 & \pm 0.39 & 4 & 5.2 & \pm 0.39 & 0,4 & 5.0 & \pm 0.39 & 0,4 & 6.1 & \pm 0.19 & $0,1,2,3$ \\
\hline guide decisions I make at work. & 4.3 & \pm 0.22 & $2,3,4$ & 4.3 & \pm 0.37 & $2,3,4$ & 5.4 & \pm 0.37 & 0,1 & 5.4 & \pm 0.37 & 0,1 & 6.0 & \pm 0.18 & 0,1 \\
\hline are critical in helping me get through each workday. & 3.9 & \pm 0.26 & 3,4 & 4.2 & \pm 0.44 & 4 & 4.8 & \pm 0.44 & 4 & 4.9 & \pm 0.44 & 0 & 5.9 & \pm 0.22 & $0,1,2$ \\
\hline influence how I establish and follow P\&Ps. & 3.9 & \pm 0.24 & $1,2,3,4$ & 4.9 & \pm 0.40 & 0,4 & 5.3 & \pm 0.40 & 0 & 5.3 & \pm 0.40 & 0 & 5.9 & \pm 0.20 & 0,1 \\
\hline influence my commitment. & 4.2 & \pm 0.22 & $1,2,3,4$ & 5.2 & \pm 0.38 & 0 & 5.4 & \pm 0.38 & 0 & 5.9 & \pm 0.38 & 0 & 5.8 & \pm 0.19 & 0 \\
\hline influence my individual goals as a manager. & 3.9 & \pm 0.23 & $1,2,3,4$ & 5.1 & \pm 0.38 & 0 & 5.2 & \pm 0.38 & 0 & 5.4 & \pm 0.38 & 0 & 5.8 & \pm 0.19 & 0 \\
\hline are apparent to those with whom I work. & 3.6 & \pm 0.22 & $2,3,4$ & 4.0 & \pm 0.37 & 3,4 & 4.7 & \pm 0.37 & 0 & 5.2 & \pm 0.37 & 0,1 & 5.4 & \pm 0.18 & 0,1 \\
\hline are a normal part of my discussions with coworkers & 2.8 & \pm 0.29 & 3,4 & 2.8 & \pm 0.50 & 3,4 & 2.9 & \pm 0.52 & 4 & 4.2 & \pm 0.50 & 0,1 & 4.1 & \pm 0.25 & $0,1,2$ \\
\hline Spiritual Influence Score (SIS) ${ }^{\mathrm{c}}$ & 43.9 & \pm 2.14 & $2,3,4$ & 50.0 & \pm 3.57 & 4 & 54.7 & \pm 3.71 & 0.4 & 59.2 & \pm 3.57 & 0 & 63.6 & \pm 1.78 & $0,1,2$ \\
\hline Table 5b. Employee Responses & $\mathbf{n}=1$ & & & & 55 & & $\mathbf{n}=$ & & & & $=50$ & & & 187 & \\
\hline $\begin{array}{l}\text { My religious beliefs/spirituality... } \\
\text { help me deal with stressful situations. }\end{array}$ & 4.9 & \pm 0.11 & $1,2,3,4$ & 5.5 & \pm 0.18 & $0,3,4$ & 5.8 & \pm 0.17 & 0,4 & 6.0 & \pm 0.20 & 0,1 & 6.4 & \pm 0.10 & $0,1,2$ \\
\hline guide my interactions with coworkers. & 4.4 & \pm 0.11 & $1,2,3,4$ & 4.9 & \pm 0.18 & $0,2,3,4$ & 5.6 & \pm 0.17 & $0,1,4$ & 5.6 & \pm 0.19 & $0,1,4$ & 6.1 & \pm 0.10 & $0,1,2,3$ \\
\hline drive my work ethic. & 4.6 & \pm 0.11 & $1,2,3,4$ & 5.1 & \pm 0.19 & $0,2,3,4$ & 5.7 & \pm 0.17 & $0,1,4$ & 5.7 & \pm 0.20 & $0,1,4$ & 6.2 & \pm 0.10 & $0,1,2,3$ \\
\hline supply me with wisdom/insight. & 4.2 & \pm 0.11 & $1,2,3,4$ & 4.9 & \pm 0.19 & $0,3,4$ & 5.4 & \pm 0.19 & 0,4 & 5.5 & \pm 0.21 & 0,1 & 5.9 & \pm 0.11 & $0,1,2$ \\
\hline guide decisions I make at work. & 4.3 & \pm 0.11 & $1,2,3,4$ & 4.9 & \pm 0.18 & $0,2,4$ & 5.5 & \pm 0.18 & $0,1,4$ & 5.4 & \pm 0.20 & 0,4 & 6.0 & \pm 0.10 & $0,1,2,3$ \\
\hline are critical in helping me get through each workday. & 4.1 & \pm 0.12 & $1,2,3,4$ & 4.8 & \pm 0.21 & $0,3,4$ & 5.2 & \pm 0.20 & 0,4 & 5.4 & \pm 0.23 & $0,1,4$ & 5.9 & \pm 0.11 & $0,1,2$ \\
\hline influence how I follow P\&Ps. & 4.4 & \pm 0.11 & $2,3,4$ & 4.8 & \pm 0.20 & $2,3,4$ & 5.7 & \pm 0.19 & 0,1 & 5.3 & \pm 0.21 & 0,4 & 6.0 & \pm 0.11 & $0,1,3$ \\
\hline influence my commitment. & 4.5 & \pm 0.11 & $2,3,4$ & 4.8 & \pm 0.18 & $2,3,4$ & 5.6 & \pm 0.17 & $0,1,4$ & 5.6 & \pm 0.19 & 0,1 & 6.0 & \pm 0.10 & $0,1,2$ \\
\hline influence my individual goals as an employee. & 4.4 & \pm 0.11 & $1,2,3,4$ & 5.0 & \pm 0.19 & $0,2,4$ & 5.6 & \pm 0.18 & 0,1 & 5.2 & \pm 0.20 & 0,4 & 6.0 & \pm 0.10 & $0,1,3$ \\
\hline are apparent to those with whom I work. & 3.7 & \pm 0.11 & $1,2,3,4$ & 4.5 & \pm 0.18 & 0,4 & 4.8 & \pm 0.17 & 0,4 & 4.9 & \pm 0.19 & 0,4 & 5.5 & \pm 0.10 & $0,1,2,3$ \\
\hline are a normal part of my discussions with coworkers. & 2.8 & \pm 0.12 & $1,2,3,4$ & 3.5 & \pm 0.21 & $0,3,4$ & 4.1 & \pm 0.20 & 0 & 4.1 & \pm 0.23 & 0,1 & 4.5 & \pm 0.12 & 0,1 \\
\hline Spiritual Influence Score $(S I S)^{\mathrm{c}}$ & 46.1 & \pm 1.03 & $1,2,3,4$ & 52.8 & \pm 1.76 & $0,2,3,4$ & 58.7 & \pm 1.67 & $0,1,4$ & 58.5 & \pm 1.93 & $0,1,4$ & 64.7 & $\pm 0,95$ & $0,1,2,3$ \\
\hline
\end{tabular}

\footnotetext{
${ }^{a}$ Responses were based on a seven-point scale from 1-7 (1-strongly disagree to 7-strongly agree).

${ }^{b}$ Religiosity Score was given according to attendance of worship service in the past month. Scores ranged from 0-4 (0-no attendance to 4-four or more times)

'SIS: Represented the sum of all answer codes for the above questions from Section A answered by either directors or employees
}

${ }^{0-4}$ LS Means with different superscripts for each Religiosity Score are significantly different from each other. ANOVA, $p$-value of at least 0.05 . 
Table 6. Influence of Religious Beliefs/Spirituality on Work Practices ${ }^{\mathrm{a}}$ by Spirituality Score

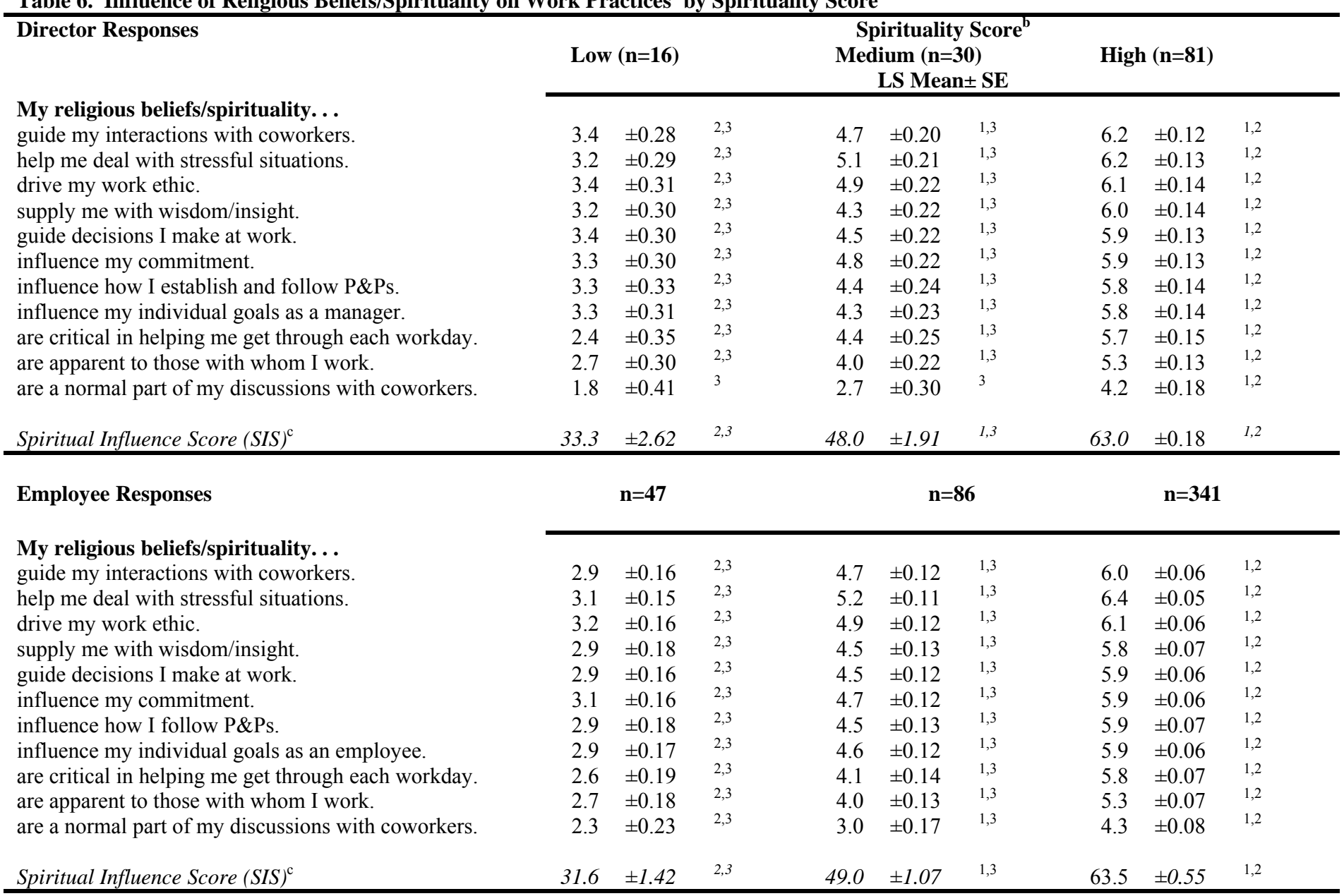

$31.6 \pm 1.42 \quad 2,3$

$49.0 \quad \pm 1.07 \quad 1,3$

$63.5 \quad \pm 0.55 \quad 1,2$

${ }^{a}$ Responses were based on a seven-point scale from 1-7 (1-strongly disagree to 7-strongly agree)

${ }^{\mathrm{b}}$ Spirituality Score range from 0-11 and is obtained by summing the results of the influence of religious/spiritual beliefs on daily life

(0-strongly disagree to 6-strongly agree) and frequency of prayer or meditation (0-never to 5-daily).

'SIS: Represented the sum of all answer codes for the above questions from Section A answered by either directors or employees.

${ }^{0-4}$ LS Means with different superscripts for each Spirituality Score are significantly different from each other. ANOVA, p-value of at least 0.05 . 


\section{Religious/Spiritual Workplace Actions}

Directors' and employees' religious/spiritual actions (Section B of questionnaire) were more apparent in the workplace as Religiosity and Spirituality Scores increased. In other words the mean scores (on a scale of $1=$ strongly disagree to $7=$ strongly agree) increased as Religiosity and Spirituality Scores increased (Tables 7 and 8). Participants with higher Religiosity and Spirituality Scores had increasing levels of agreement that they pray about work related issues, have spiritual/religious feelings at work, and rely on spiritual insight to make decisions at work (Tables 7 and 8).

The Spiritual Action Score (SAS), which was the summed means of questions from section B, increased as the directors' and employees' Religiosity and Spirituality Scores increased (Table 7 and 8). Directors' Religiosity and Spirituality Scores were both positively correlated to the directors' SAS. The Spirituality Score ( $\mathrm{R}-\mathrm{Sq}=0.81$; $\mathrm{p}<0.0001)$ had a higher correlation than was seen with the Religiosity Score $(\mathrm{R}-\mathrm{Sq}=0.57$; $\mathrm{p}<0.0001)$. There was also a positive correlation between the employees' Religiosity (R$\mathrm{Sq}=0.48 ; \mathrm{p}<0.0001)$ and Spirituality $(\mathrm{R}-\mathrm{Sq}=0.75 ; \mathrm{p}<0.0001)$ Scores and SAS.

\section{Trustworthiness}

\section{Directors' Trustworthiness}

The majority of directors believe that their employees consider them to be fair (98.45\%), honest and trustworthy (97.67\%), easily approachable $(96.90 \%)$, and a person whose actions reflect their beliefs $(89.15 \%)$. Generally, their employees' perceptions were lower. Employees' perceived their directors as being fair $(87.64 \%)$, honest and trustworthy (85.11\%), easily approachable (87.43\%), and a person whose actions reflect 
Table 7. Spiritual Actions ${ }^{\mathrm{a}}$ by Religiosity Score

Director Responses

\section{$0(n=38)$}

$1(n=13)$

Religiosity Score $2(n=13)$

LS Mean \pm SE

I Often. ..

follow God's (a Supreme Being's) example. have spiritual/religious feelings at work.

rely on spiritual insight in making decisions.

pray about work-related issues.

Spiritual Action Score (SAS)

\begin{tabular}{rrrrrrrr}
\hline 3.8 & \pm 0.23 & $2,3,4$ & 4.2 & \pm 0.39 & 4 & 4.9 & \pm 0.39 \\
3.2 & \pm 0.26 & $2,3,4$ & 3.7 & \pm 0.44 & 4 & 4.4 & \pm 0.44 \\
3.4 & \pm 0.26 & $2,3,4$ & 3.8 & \pm 0.44 & 4 & 4.5 & \pm 0.44 \\
3.0 & \pm 0.29 & $2,3,4$ & 3.5 & \pm 0.49 & 4 & 4.3 & \pm 0.49 \\
& & & & & & & \\
13.5 & \pm 0.93 & $2,3,4$ & 15.2 & \pm 1.57 & 4 & 18.1 & \pm 1.57
\end{tabular}

\begin{tabular}{lllllll}
0,4 & 5.2 & \pm 0.39 & 0 & 5.9 & \pm 0.20 & $0,1,2$ \\
0,4 & 4.8 & \pm 0.44 & 0 & 5.7 & \pm 0.22 & $0,1,2$ \\
0,4 & 4.8 & \pm 0.44 & 0 & 5.5 & \pm 0.22 & $0,1,2$ \\
0 & 4.5 & \pm 0.49 & 0 & 5.3 & \pm 0.24 & 0,1 \\
& & & & & & \\
0.4 & 19.4 & \pm 1.57 & 0 & 22.5 & \pm 0.79 & $0,1,2$ \\
\hline
\end{tabular}

\section{Employee Responses}

I Often. ..

follow God's (a Supreme Being's) example. have spiritual/religious feelings at work.

rely on spiritual insight in making decisions.

pray about work-related issues.

$\mathbf{n}=162$

\section{$\mathrm{n}=162$}

$\mathbf{n}=55$

$\mathbf{n}=61$

$\mathbf{n}=\mathbf{5 0}$

$\mathbf{n}=187$

\begin{tabular}{rrrrlllllllllll}
\hline 4.1 & \pm 0.12 & $1,2,3,4$ & 4.7 & \pm 0.20 & 0,4 & 5.2 & \pm 0.19 & 0,4 & 5.2 & \pm 0.21 & 0,4 & 5.8 & \pm 0.11 & $0,1,2,3$ \\
3.7 & \pm 0.12 & $1,2,3,4$ & 4.3 & \pm 0.21 & $0,3,4$ & 4.8 & \pm 0.20 & 0,4 & 5.1 & \pm 0.22 & 0,1 & 5.5 & \pm 0.11 & $0,1,2$ \\
3.7 & \pm 0.12 & $1,2,3,4$ & 4.2 & \pm 0.21 & $0,2,3,4$ & 4.9 & \pm 0.20 & $0,1,4$ & 4.9 & \pm 0.22 & $0,1,4$ & 5.4 & \pm 0.11 & $0,1,2,3$ \\
3.4 & \pm 0.13 & $1,2,3,4$ & 4.1 & \pm 0.23 & $0,3,4$ & 4.7 & \pm 0.22 & 0,4 & 4.8 & \pm 0.24 & $0,1,4$ & 5.5 & \pm 0.12 & $0,1,2,3$ \\
& & & & & & & & & & & & & & \\
15.0 & \pm 0.44 & $1,2,3,4$ & 17.4 & \pm 0.76 & $0,2,3,4$ & 19.6 & \pm 0.72 & $0,1,4$ & 20.1 & \pm 0.80 & $0,1,4$ & 20.1 & \pm 0.41 & $0,1,2,3$ \\
\hline
\end{tabular}

Spiritual Action Score (SAS)

${ }^{\mathrm{a}}$ Responses were based on a seven-point scale from 1-7 (1-strongly disagree to 7-strongly agree)

${ }^{b}$ Religiosity Score was given according to attendance of worship service in the past month. Scores ranged from 0-4 (0-no attendance to 4-four or more times)

${ }^{c}$ SAS: Represented the sum of all answer codes for the above questions from Section Banswered by either directors or employees.

${ }^{0-4}$ LS Means with different superscripts for each Religiosity Score are significantly different from each other. ANOVA, p-value of at least 0.05 . 
Table 8. Spiritual Actions ${ }^{\mathrm{a}}$ by Spirituality Score

\begin{tabular}{|c|c|c|c|c|c|c|c|c|c|}
\hline \multirow[b]{2}{*}{$\begin{array}{l}\text { I Often... } \\
\text { follow God's (a Supreme Being's) example. } \\
\text { have spiritual/religious feelings at work. } \\
\text { rely on spiritual insight in making decisions. } \\
\text { pray about work-related issues. }\end{array}$} & \multicolumn{3}{|c|}{ Low $(n=16)$} & \multicolumn{3}{|c|}{$\begin{array}{l}\text { Medium }(n=30) \\
\text { LS Mean } \pm \text { SE }\end{array}$} & \multicolumn{3}{|c|}{ High $(n=81)$} \\
\hline & $\begin{array}{l}2.5 \\
1.8 \\
2.2 \\
1.8\end{array}$ & $\begin{array}{l} \pm 0.30 \\
\pm 0.33 \\
\pm 0.33 \\
\pm 0.37\end{array}$ & $\begin{array}{l}2,3 \\
2,3 \\
2,3 \\
2,3\end{array}$ & $\begin{array}{l}4.3 \\
3.6 \\
3.5 \\
3.1\end{array}$ & $\begin{array}{l} \pm 0.22 \\
\pm 0.24 \\
\pm 0.24 \\
\pm 0.27\end{array}$ & $\begin{array}{l}1,3 \\
1,3 \\
1,3 \\
1,3\end{array}$ & $\begin{array}{l}5.7 \\
5.5 \\
5.5 \\
5.3\end{array}$ & $\begin{array}{l} \pm 0.14 \\
\pm 0.15 \\
\pm 0.15 \\
\pm 0.16\end{array}$ & $\begin{array}{l}1,2 \\
1,2 \\
1,2 \\
1,2\end{array}$ \\
\hline Spiritual Action Score $(S A S)^{\mathrm{c}}$ & 8.2 & \pm 1.12 & 2,3 & 14.5 & \pm 0.82 & 1,3 & 22.0 & \pm 0.50 & 1,2 \\
\hline Employee Responses & & $n=47$ & & & $\mathbf{n}=\mathbf{8 0}$ & & & $\mathrm{n}=341$ & \\
\hline $\begin{array}{l}\text { I Often... } \\
\text { follow God's (a Supreme Being's) example. } \\
\text { have spiritual/religious feelings at work. } \\
\text { rely on spiritual insight in making decisions. } \\
\text { pray about work-related issues. }\end{array}$ & $\begin{array}{l}2.5 \\
2.3 \\
2.4 \\
1.9\end{array}$ & $\begin{array}{l} \pm 0.17 \\
\pm 0.19 \\
\pm 0.19 \\
\pm 0.21\end{array}$ & $\begin{array}{l}2,3 \\
2,3 \\
2,3 \\
2,3\end{array}$ & $\begin{array}{l}4.4 \\
3.9 \\
3.9 \\
3.7\end{array}$ & $\begin{array}{l} \pm 0.13 \\
\pm 0.14 \\
\pm 0.14 \\
\pm 0.15\end{array}$ & $\begin{array}{l}1,3 \\
1,3 \\
1,3 \\
1,3\end{array}$ & $\begin{array}{l}5.7 \\
5.5 \\
5.4 \\
5.4\end{array}$ & $\begin{array}{l} \pm 0.06 \\
\pm 0.07 \\
\pm 0.07 \\
\pm 0.08\end{array}$ & $\begin{array}{l}1,2 \\
1,2 \\
1,2 \\
1,2\end{array}$ \\
\hline Spiritual Action Score $(S A S)^{\mathrm{c}}$ & 9.0 & \pm 0.63 & 2,3 & 15.8 & \pm 0.47 & 1,3 & 22.0 & \pm 0.24 & 1,2 \\
\hline
\end{tabular}

${ }^{a}$ Responses were based on a seven-point scale from 1-7 (1-strongly disagree to 7-strongly agree)

${ }^{\mathrm{b}}$ Spirituality Score range from 0-11 and is obtained by summing the results of the influence of religious/spiritual beliefs on daily life (0-strongly disagree to 6-strongly agree) and frequency of prayer or meditation (0-never to 5-daily).

${ }^{\mathrm{c}} \mathrm{SAS}$ : Represented the sum of all answer codes for the above questions from Section B answered by either directors or employees.

${ }^{0-4}$ LS Means with different superscripts for each Spirituality Score are significantly different from each other.

ANOVA, p-value of at least 0.05 . 
his/her beliefs (73.14\%). These differences were not significant except for the perception of the director being honest and trustworthy $(\mathrm{t}=3.01 ; \mathrm{p}=0.0003)$. Collective responses and differences are found in Tables 9 and 10.

Trust was further explored through questions from Section E (Questions 30, 41, 42, 44, 46). Most directors (94.57\%) claimed to frequently go beyond self-interest for the good of the group, $93.75 \%$ thought they acted in ways that builds others' respect for them, and $90.55 \%$ believe they treat others as individuals (Table 11). When employees were asked these same questions regarding their director they responded that only $69.04 \%$ of directors go beyond self-interest for the good of the group, $68.32 \%$ act in a way that builds others' respect for them, and $79.19 \%$ treat others as individuals (Table 11). Just under one-third of directors (32.03\%) and employees (32.17\%) agreed that either they, as the directors, or their director frequently discloses their most important values and beliefs at work (Table 11). The differences between these responses were all significant (Table 10).

Questions from Sections C and E on the director survey and the employee survey were summed to generate two distinct Director Trust Scores (DTS): (1) the DTS from the director survey rated by the director himself/herself, and (2) the DTS score from the employee survey rated by the director's employees. Using a two-sample t-test, analysis of the difference between the two DTS indicated that directors rated themselves as being more trustworthy than did their employees $(\mathrm{t}=4.33 ; \mathrm{p}<0.0001)$ (Table 10). 
Table 9. Trustworthiness of Directors

\begin{tabular}{|c|c|c|c|c|c|c|}
\hline \multirow[t]{2}{*}{ Director Responses } & \multicolumn{2}{|c|}{ Agree $^{\mathrm{a}}$} & \multicolumn{2}{|c|}{ Neutral } & \multicolumn{2}{|c|}{ Disagree } \\
\hline & $\mathbf{n}$ & $\%$ & $\mathbf{n}$ & $\%$ & $\mathbf{n}$ & $\%$ \\
\hline $\begin{array}{l}\text { Section C. In general, my employees view me as... } \\
\text { fair. }\end{array}$ & 127 & 98.45 & 2 & 1.55 & 0 & 0.00 \\
\hline honest and trustworthy. & 126 & 97.67 & 3 & 2.33 & 0 & 0.00 \\
\hline easily approachable. & 125 & 96.90 & 4 & 3.10 & 0 & 0.00 \\
\hline a person whose actions reflect my beliefs. & 115 & 89.15 & 11 & 8.52 & 3 & 2.33 \\
\hline
\end{tabular}

\section{Employee Responses}

Section C. In general, my director/manager is... fair. honest and trustworthy. easily approachable.

a person whose actions reflect his/her beliefs.

$\begin{array}{llllll}461 & 87.64 & 26 & 4.19 & 43 & 8.17 \\ 446 & 85.11 & 37 & 7.07 & 41 & 7.82 \\ 459 & 87.43 & 16 & 3.05 & 50 & 9.52 \\ 384 & 73.14 & 93 & 17.72 & 48 & 9.14\end{array}$

${ }^{a}$ Responses have been collapsed into three categories: (1) Agree ('Strongly Agree, Agree, and Somewhat Agree'), (2) Neutral ('Neither Agree or Disagree'), and (3) Disagree ('Somewhat Disagree, Disagree, and Strongly Disagree').

Table 10. Director and Employee Response Differences for Trust Questions (Director - Employee Responses)

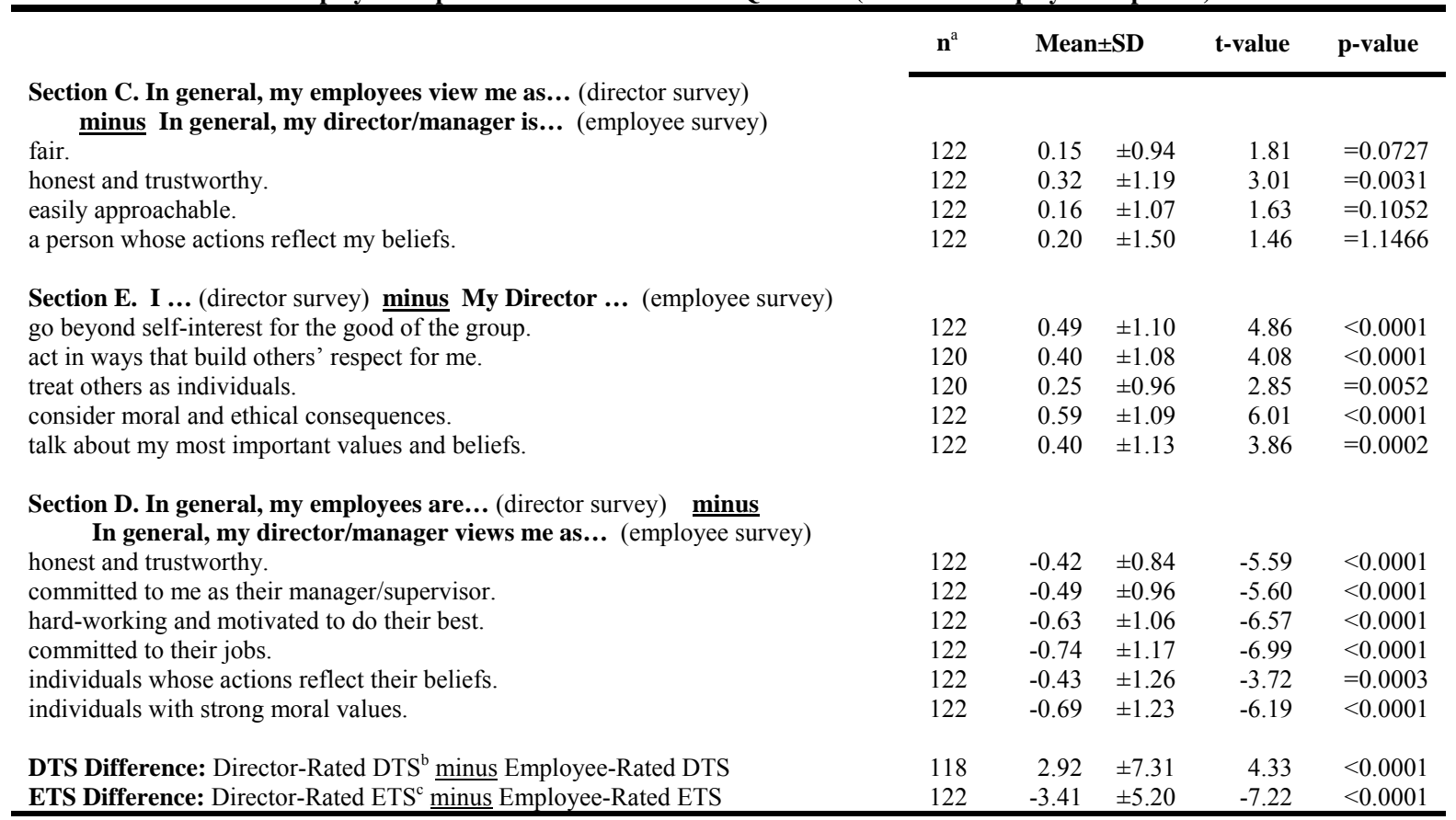

${ }^{a}$ Numbers of subjects differ due to varying response rate.

${ }^{\mathrm{b}}$ DTS: Represented the sum of all answer codes for the above questions from Sections C and E (questions \#30, 41, 42, 44, and 46) answered by either directors or employees.

${ }^{c}$ ETS: Represented the sum of all answer codes for the above questions from Section D answered by either directors or employees. 
Table 11. Trustworthy Actions of Directors

\begin{tabular}{|c|c|c|c|c|c|c|}
\hline \multirow[t]{2}{*}{ Director Responses } & \multicolumn{2}{|c|}{ Frequently $^{\mathrm{a}}$} & \multicolumn{2}{|c|}{ Sometimes } & \multicolumn{2}{|c|}{ Not at all } \\
\hline & $\mathbf{n}$ & $\%$ & $\mathbf{n}$ & $\%$ & $\mathbf{n}$ & $\%$ \\
\hline $\begin{array}{l}\text { Section E. I ... } \\
\text { go beyond self-interest for the good of the group. }\end{array}$ & & 94.5 & & 5.43 & 0 & \\
\hline act in ways that build others' respect for me. & 120 & 93.75 & 8 & 6.25 & 0 & 0 \\
\hline treat others as individuals. & 115 & 90.55 & 11 & 8.66 & 1 & 0.79 \\
\hline consider moral and ethical consequences. & 116 & 89.92 & 13 & 10.08 & 0 & 0 \\
\hline talk about my most important values and beliefs. & 41 & 32.03 & 80 & 62.5 & 7 & 5.47 \\
\hline
\end{tabular}

\section{Employee Responses}

\section{Section E. My Director ...}

Goes beyond self-interest for the good of the group.

Acts in ways that build my respect.

Treats me as an individual.

Considers moral and ethical consequences.

Talks about their most important values and beliefs.

\begin{tabular}{llll}
359 & 69.04 & 131 & 25.19 \\
354 & 68.21 & 135 & 26.01 \\
411 & 79.19 & 87 & 16.76 \\
347 & 67.38 & 147 & 28.54 \\
166 & 32.17 & 260 & 50.39 \\
\hline
\end{tabular}

$30 \quad 5.77$

$30-5.78$

$21 \quad 4.05$

$21 \quad 4.08$

$90 \quad 17.44$

: (1) Frequently ('Frequently, if not always and Fairly often'), (2) Sometimes ('Sometimes'), and (3) Not at all ('Once in a while and Not at all').

Table 12. Trustworthiness of Employees

Director Responses

Section D. In general, my employees are..

honest and trustworthy.

committed to me as their manager/supervisor.

hard-working and motivated to do their best.

committed to their jobs.

individuals whose actions reflect their beliefs.

individuals with strong moral values.

\begin{tabular}{llllll} 
Agree $^{\mathbf{a}}$ & \multicolumn{2}{c}{ Neutral } & \multicolumn{2}{c}{ Disagree } \\
$\mathbf{n}$ & $\mathbf{\%}$ & $\mathbf{n}$ & $\mathbf{\%}$ & $\mathbf{n}$ & $\mathbf{0}$ \\
\hline & & & & & \\
122 & 94.57 & 5 & 3.88 & 2 & 1.55 \\
115 & 89.15 & 12 & 9.30 & 2 & 1.55 \\
114 & 88.37 & 10 & 7.75 & 5 & 3.88 \\
111 & 86.05 & 11 & 8.52 & 7 & 5.43 \\
104 & 80.62 & 4 & 13.95 & 7 & 5.43 \\
101 & 78.29 & 18 & 13.96 & 10 & 7.75 \\
\hline
\end{tabular}

\section{Employee Responses}

Section D. In general, my director/manager views me as...

honest and trustworthy.

committed to them as my manager/supervisor.

hard-working and motivated to do my best.

committed to my job.

an individual whose actions reflect my beliefs.

\begin{tabular}{llllll}
\hline & & & & & \\
496 & 94.30 & 23 & 4.37 & 7 & 1.33 \\
482 & 93.63 & 34 & 6.47 & 10 & 1.90 \\
501 & 95.25 & 19 & 3.61 & 6 & 1.14 \\
499 & 95.05 & 20 & 3.81 & 6 & 1.14 \\
434 & 82.51 & 83 & 15.78 & 9 & 1.71 \\
478 & 90.87 & 39 & 7.42 & 9 & 1.71 \\
\hline
\end{tabular}

7.42

1.71

${ }^{a}$ Responses have been collapsed into three categories: (1) Agree ('Strongly Agree, Agree, and Somewhat Agree'), (2) Neutral ('Neither Agree or Disagree'), and (3) Disagree ('Somewhat Disagree, Disagree, and Strongly Disagree’). 


\section{Employees’ Trustworthiness}

Similar to the questions asked regarding the trustworthiness of the directors, Section D investigated the trustworthiness of participating employees. Comprehensive responses to questions are found in Table 12. Responses by the employees themselves and their directors were similar. For example, $94.3 \%$ of employees thought their director perceived them as being honest and trustworthy, which the majority did (94.57\%). The majority of employees believe that their directors considered them to be hard-working and motivated (95.25\%), committed to their job (95.05\%), and committed to their supervisor (93.63\%), compared to their directors' response of $88.37 \%, 86.05 \%$, and $89.15 \%$ respectively. There was even greater variation between the employees' belief that their directors perceived them as individuals with strong moral values $(90.87 \%)$ and the actual perception of their directors (78.29\%). Director and employee responses were significantly different for each of the individual questions, with the employees' responses being greater than the directors' responses (Table 10).

Similar to the DTS, an Employee Trust Score (ETS) was generated by summing the responses from Section D on both the director and employee surveys. As with the directors, the two-sample t-test analysis of the ETS differences illustrated that employees generally thought their directors would perceive their (the employees') trustworthiness higher than what the directors perception actually was $(\mathrm{t}=-7.22, \mathrm{p}<0.0001)($ Table 10$)$. These findings are dissimilar to Patterson and Kim's (24) national survey which reported that both management and workers rated workers as being more trustworthy than directors. 


\section{Trust by Religiosity and Spirituality Scores}

Analysis of variance (ANOVA) was used to assess the influence of the Religiosity and Spirituality Scores on trust. Individual questions investigating trust were compared to both the Religiosity and Spirituality Scores. Using ANOVA and Pearson's Correlation, summed trust scores (DTS and ETS) were compared to both the directors' and employees' Religiosity and Spirituality Scores.

\section{Self-Rated Directors’ Trust by Directors’ Religiosity and Spirituality Scores}

Directors' responses to how they believed their employees viewed their trustworthiness (questions from Sections C) and their trust-related actions (questions 30, 41, 42, 44, 46 from Section E) were compared to their own Religiosity and Spirituality Scores (Table 13a and 14a). There were no consistent patterns found among the questions. Directors who had Religiosity Scores of 0, 1, 3 and 4 rated themselves as being perceived by their employees as being more easily approachable and acting in ways that build others' respect for themselves than did directors with Religiosity Scores of 2. There were no differences seen in these three questions when compared to the Spirituality Score. Those with the highest Religiosity Score [4] thought they were perceived as being more honest than those with a Religiosity Score of 2. However, there was no significant difference seen in the other Religiosity Score levels or in any of the Spirituality Score levels. Directors who had a Religiosity Score of at least 4 marked that they consider moral and ethical consequences significantly more than did those who had a Religiosity Score of 0 . The only significant difference seen by Spirituality Score was that directors with the highest Spirituality Score claimed to disclose their most important values and 
Table 13. Director's Trust ${ }^{\text {ab }}$ by Director's Religiosity Score

\begin{tabular}{|c|c|c|c|c|c|c|c|c|c|c|c|c|c|c|c|}
\hline \multirow{2}{*}{$\begin{array}{l}\text { 13a. Director Responses } \\
\text { In general, my employees view me as ... }\end{array}$} & \multicolumn{3}{|c|}{$0(n=38)$} & \multicolumn{2}{|c|}{$1(n=13)$} & \multicolumn{4}{|c|}{$\begin{array}{l}2(n=13) \\
\quad \text { LS Mean } \pm \text { SE }\end{array}$} & \multicolumn{2}{|c|}{$3(n=13)$} & \multicolumn{4}{|c|}{$4(n=52)$} \\
\hline & 60 & +010 & 2 & 50 & +017 & & & +017 & 0.34 & 60 & +017 & 2 & 63 & $+\cap \Omega \rho$ & 2 \\
\hline honest and trustworthy. & 6.1 & \pm 0.11 & & 6.2 & \pm 0.19 & & $\begin{array}{l}5.3 \\
5.8\end{array}$ & $\begin{array}{l} \pm 0.17 \\
\pm 0.19\end{array}$ & 4 & $\begin{array}{l}0.0 \\
6.2\end{array}$ & $\begin{array}{l} \pm 0.17 \\
\pm 0.19\end{array}$ & & $\begin{array}{l}0.3 \\
6.3\end{array}$ & $\begin{array}{l} \pm 0.00 \\
\pm 0.10\end{array}$ & 2 \\
\hline easily approachable & 6.1 & \pm 0.12 & 2 & 6.1 & \pm 0.21 & 2 & 5.4 & \pm 0.21 & $0,1,3,4$ & 6.1 & \pm 0.21 & 2 & 6.2 & \pm 0.10 & 2 \\
\hline $\begin{array}{l}\text { a person whose actions reflects my beliefs } \\
\text { I ... }\end{array}$ & 5.6 & \pm 0.17 & & 5.3 & \pm 0.29 & 4 & 5.5 & \pm 0.29 & & 5.8 & \pm 0.29 & & 6.0 & \pm 0.14 & 1 \\
\hline consider moral and ethical consequences. & 5.7 & \pm 0.18 & 4 & 5.8 & \pm 0.30 & & 6.3 & \pm 0.30 & & 6.3 & \pm 0.30 & & 6.3 & \pm 0.15 & 0 \\
\hline treat others as individuals. & 6.1 & \pm 0.18 & & 6.1 & \pm 0.30 & & 6.0 & \pm 0.30 & & 6.1 & \pm 0.30 & & 6.1 & \pm 0.15 & \\
\hline go beyond self-interest for the good of the group. & 6.1 & \pm 0.14 & & 5.8 & \pm 0.24 & & 6.3 & \pm 0.24 & & 6.0 & \pm 0.24 & & 6.0 & \pm 0.12 & \\
\hline act in ways that build others' respect for me. & 6.1 & \pm 0.15 & 2 & 6.0 & \pm 0.26 & 2 & 5.2 & \pm 0.26 & $0,1,3,4$ & 6.0 & \pm 0.26 & 2 & 5.8 & \pm 0.12 & 2 \\
\hline talk about my most important values and beliefs. & 4.0 & \pm 0.24 & 3,4 & 3.6 & \pm 0.41 & 3,4 & 4.2 & \pm 0.41 & 3 & 5.2 & \pm 0.41 & $0,1,2$ & 4.6 & \pm 0.20 & 0,1 \\
\hline Director Trust Score (DTS) ${ }^{\mathrm{d}}$ & 39.1 & \pm 0.64 & & 38.5 & \pm 1.10 & & 31.2 & \pm 1.10 & 3,4 & 40.5 & \pm 1.10 & 2 & 40.6 & \pm 056 & 2 \\
\hline
\end{tabular}

13b. Employee Responses

$\mathrm{n}=162$

$n=55$

$n=61$

$n=50$

$\mathbf{n}=187$

In general, my director/manager is ...

fair.

honest and trustworthy.

easily approachable.

$\begin{array}{ll}5.9 & \pm 0.17 \\ 5.7 & \pm 0.20\end{array}$

$5.9 \pm 0.18$

$5.4 \pm 0.20$

My Director ... b

Considers moral and ethical consequences.

Treats me as an individual.

Goes beyond self-interest for the good of the group

Acts in ways that build my respect.

Talks about their most important values and beliefs.

$5.5 \pm 0.20$

$5.5 \pm 0.23$

$5.2 \pm 0.24$

$3.7 \pm 0.24$

$47.9 \quad \pm 1.52$

Director Trust Score (DTS) ${ }^{\mathrm{d}}$

$5.9 \pm 0.29$

$5.8 \pm 0.35$

$6.1 \pm 0.31$

$5.2 \pm 0.34$

$\begin{array}{ll}4.9 & \pm 0.38\end{array}$

$\begin{array}{ll}5.7 & \pm 0.33\end{array}$

$5.2 \pm 0.39$

$5.2 \pm 0.41$

$3.4 \pm 0.42$

$46.9 \pm 2.60$

$5.7 \quad \pm 0.29$

$5.8 \pm 0.35$

$5.5 \pm 0.31$

$5.2 \pm 0.34$

$\begin{array}{ll}5.1 & \pm 0.38\end{array}$

$\begin{array}{ll}5.7 & \pm 0.33\end{array}$

$\begin{array}{ll}4.6 & \pm 0.39\end{array}$

$4.6 \pm 0.44$

$2.8 \pm 0.42$

$44.5 \quad \pm 2.71$

$48.9 \quad \pm 2.50$

$5.8 \pm 0.2$

$5.9 \pm 0.3$

$\begin{array}{ll}5.8 & \pm 0.30 \\ 5.6 & \pm 0.33\end{array}$

$5.4 \pm 0.36$

$5.8 \pm 0.32$

$\begin{array}{ll}5.8 & \pm 0.32 \\ 5.2 & \pm 0.38\end{array}$

$5.5 \quad \pm 0.39$

$5.9 \quad \pm 0.14$

$5.9 \pm 0.17$

$6.0 \pm 0.15$

${ }^{a}$ Responses were based on a seven-point scale from 1-7 (1-strongly disagree to 7-strongly agree)

${ }^{\mathrm{b}}$ Responses were converted to a seven-point scale from 1-7 (1-Frequently, if not always to 7-not at all).

Religiosity Score was given according to attendance of worship service in the past month. Scores ranged from 0-4 (0-no attendance to 4-four or more times).

${ }^{d}$ DTS: Represented the sum of all answer codes for the above questions from Section C and E (questions \#30, 41, 42, 44, and 46) answered by either directors or employees.

${ }^{0-4}$ LS Means with different superscripts for each Religiosity Score are significantly different from each other. ANOVA, p-value of at least 0.05 . 
Table 14. Director's Trust ${ }^{\mathrm{ab}}$ by Director's Spirituality Score

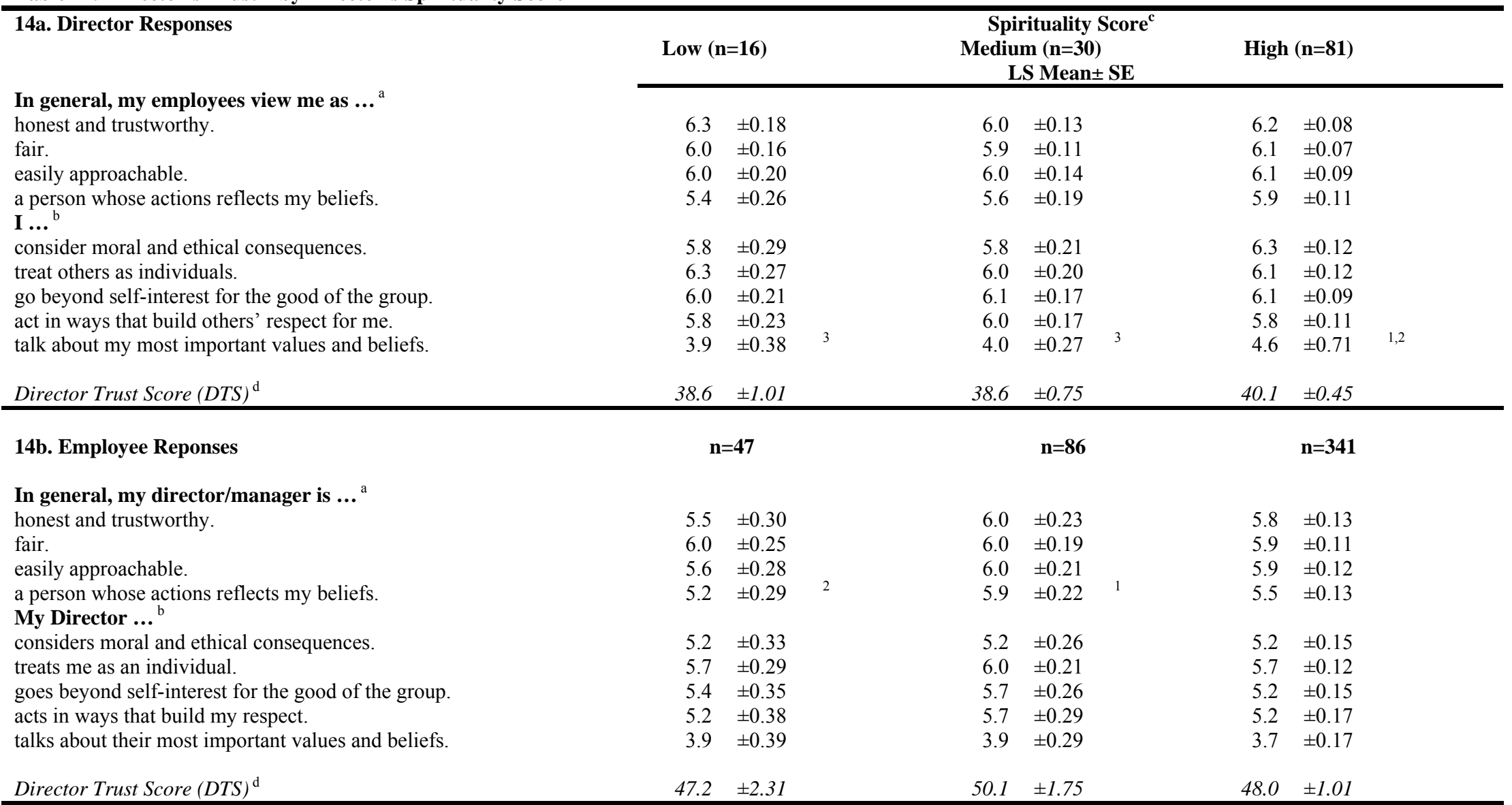

${ }^{a}$ Responses were based on a seven-point scale from 1-7 (1-strongly disagree to 7-strongly agree).

${ }^{\mathrm{b}}$ Responses were converted to a seven-point scale from 1-7 (1-Frequently, if not always to 7-not at all).

${ }^{\mathrm{c}}$ Spirituality Score range from $0-11$ and is obtained by summing the results of the influence of religious/spiritual beliefs on daily

life ( 0 -strongly disagree to 6-strongly agree) and frequency of prayer or meditation (0-never to 5-daily).

${ }^{\mathrm{d}}$ DTS: Represented the sum of all answer codes for the above questions from Section C and E (questions \#30, 41, 42, 44, and 46) answered by either directors or employees.

${ }^{0-4}$ LS Means with different superscripts for each Spirituality Score are significantly different from each other. ANOVA, p-value of at least 0.05 . 
beliefs more frequently than did those with lower Spirituality Scores. This trend was also seen as the Religiosity Score increased.

Analysis of variance of the DTS and Religiosity Score found that directors who had a Religiosity Score of 3 or 4 had a significantly higher DTS than those directors with a Religiosity Score of 2. However, there was no difference seen in those that had a Religiosity Score of 1 or less, and there were no differences seen based on the Spirituality Score (Table 13a). There was a significant Pearson's Correlation between the directorrated DTS and their Religiosity $(\mathrm{R}-\mathrm{Sq}=0.18, \mathrm{p}=0.039)$ and Spirituality $(\mathrm{R}-\mathrm{Sq}=0.26$, $\mathrm{p}=0.003$ ) Scores, with high DTS seen at higher scores.

\section{Employee-Rated Directors’ Trust by Directors' Religiosity and Spirituality Scores}

The directors' Religiosity and Spirituality Scores do not appear to influence the amount of trust that employees have in them (Table 13b and 14b). Few significant differences were found in analysis of the employees' perception of their directors' trustworthiness by the directors' Religiosity and Spirituality Scores. Employees perceived that directors with a Religiosity Score of 0,3 or 4 talked about their most important values and beliefs more often than directors with a Religiosity Score of 2. Directors with a moderate Spirituality Score were seen as persons whose actions reflected their beliefs more so than those with a low Spirituality Score. No other significant differences were seen using either the Religiosity or Spirituality Scores. Analysis of variance and Pearson's Correlation found that there were no significant relationships between the employee-rated DTS and the directors' Religiosity $(\mathrm{R}-\mathrm{Sq}=0.10, \mathrm{p}=0.26)$ and Spirituality Scores $(\mathrm{R}-\mathrm{Sq}=0.01, \mathrm{p}=0.92)$. 


\section{Employee-Rated Directors' Trust by Employees’ Religiosity and Spirituality Scores}

There was little difference seen in the way employees rated their directors'

trustworthiness based on their own Religiosity and Spirituality Scores (Table 15 and 16).

Employees with a Religiosity Score of 4 stated that their directors treat them as

individuals more often than did those employees with a Religiosity Score of only 2, but

there were no differences seen in the other three $(0,1$, and 3$)$ Religiosity Score levels.

Also, there was no difference in the way employees rated their director based on their

own Spirituality Score. Analysis of variance and Pearson's Correlation found that there

were no positive relationship between the employee-rated DTS and the employees'

Religiosity (R-Sq=0.03, $\mathrm{p}=0.57)$ and Spirituality Scores $(\mathrm{R}-\mathrm{Sq}=0.01, \mathrm{p}=0.87)$.

\section{Self-Rated Employees’ Trust by Employees’ Religiosity and Spirituality Scores}

Similar to the directors, employee responses regarding how they thought their director perceived their trustworthiness (questions from Section D) were compared to their own Religiosity and Spirituality Scores (Table 17 and 18). Again, there were no consistent trends seen among the questions. Employees who had a Religiosity Score of 4 felt that they were individuals whose actions reflected their beliefs more than those employees that had a Score of 0. Employees with high Spirituality Scores rated themselves as being individuals whose actions reflected their beliefs more than those with moderate Spirituality Scores. Those employees with Religiosity Scores of 2, reported they were viewed by their director as being more honest and trustworthy than those with a Religiosity Score of 0 . There were a few other differences seen based on Religiosity Score, however findings were inconsistent and scattered (Table 17). 
Table15. Employee-Rated Director's Trust ${ }^{\text {ab }}$ by Employees' Religiosity Score

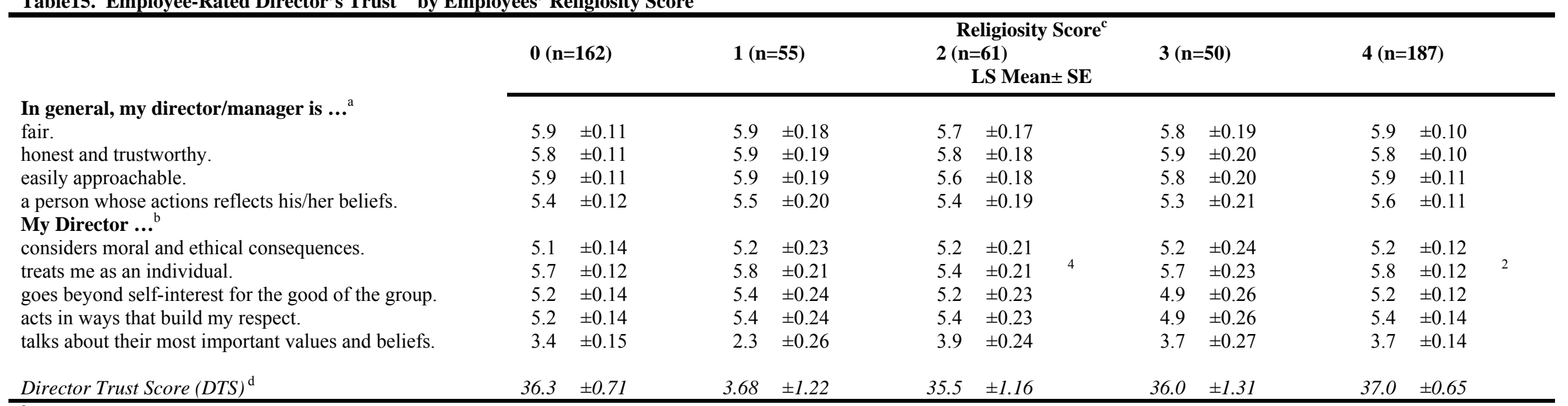

${ }^{\mathrm{a}}$ Responses were based on a seven-point scale from 1-7 (1-strongly disagree to 7-strongly agree).

${ }^{\mathrm{b}}$ Responses were converted to a seven-point scale from 1-7 (1-Frequently, if not always to 7-not at all).

${ }^{c}$ Religiosity Score was given according to attendance of worship service in the past month. Scores ranged from 0-4 (0-no attendance to 4-four or more times).

${ }^{\mathrm{d}}$ DTS: Represented the sum of all answer codes for the above questions from Section C and E (questions \#30, 41, 42, 44, and 46) answered by employees.

${ }^{0-4}$ LS Means with different superscripts for each Religiosity Score are significantly different from each other. ANOVA, $p$-value of at least 0.05 . 
Table 16. Employee-Rated Director's Trust ${ }^{\mathrm{ab}}$ by Employees' Spirituality Score

Spirituality Score

Medium (n=86)

LS Mean \pm SE

In general, my director/manager is ...

fair.

honest and trustworthy.

easily approachable.

a person whose actions reflects my beliefs.

My Director ...

considers moral and ethical consequences.

treats me as an individual.

goes beyond self-interest for the good of the group.

acts in ways that build my respect.

talks about their most important values and beliefs.

Low $(n=47)$

$\pm 0.15$

$5.9 \quad \pm 0.20$

$\begin{array}{ll}5.9 & \pm 0.20 \\ 6.0 & \pm 0.21\end{array}$

$\begin{array}{ll}6.0 & \pm 0.21 \\ 6.0 & \pm 0.21\end{array}$

$5.3 \pm 0.22$

$4.9 \pm 0.24$

$5.5 \pm 0.23$

$5.1 \pm 0.26$

$5.2 \pm 0.26$

$2.1 \quad \pm 0.27$

$35.8 \quad \pm 0.69$

Director Trust Score (DTS)

${ }^{a}$ Responses were based on a seven-point scale from 1-7 (1-strongly disagree to 7-strongly agree)

${ }^{6}$ Responses were converted to a seven-point scale from 1-7 (1-Frequently, if not always to 7-not at all).

${ }^{\mathrm{c}}$ Spirituality Score range from 0-11 and is obtained by summing the results of the influence of religious/spiritual beliefs on daily

life ( 0 -strongly disagree to 6-strongly agree) and frequency of prayer or meditation ( 0 -never to 5-daily).

${ }^{\mathrm{d}}$ DTS: Represented the sum of all answer codes for the above questions from Section C and E (questions \#30, 41, 42, 44, and 46) answered by employees.

${ }^{0-4}$ LS Means with different superscripts for each Spirituality Score are significantly different from each other. ANOVA, $p$-value of at least 0.05 . 


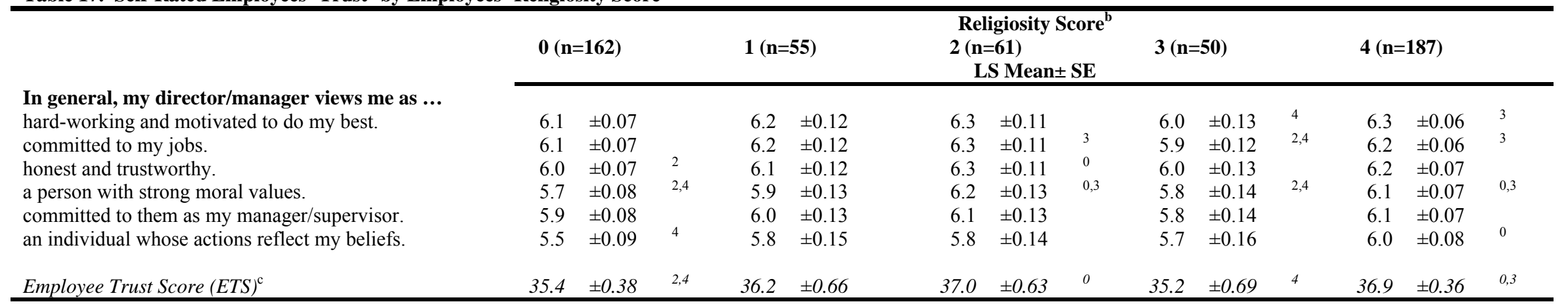

${ }^{\mathrm{a}}$ Responses were based on a seven-point scale from 1-7 (1-strongly disagree to 7-strongly agree).

${ }^{b}$ Religiosity Score was given according to attendance of worship service in the past month. Scores ranged from 0-4 (0-no attendance to 4-four or more times).

${ }^{c}$ ETS: Represented the sum of all answer codes for the above questions from Section D answered by employees.

${ }^{0-4}$ LS Means with different superscripts for each Religiosity Score are significantly different from each other. ANOVA, p-value of at least 0.05 .

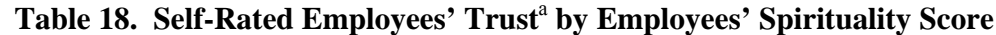

\begin{tabular}{|c|c|c|c|c|c|c|}
\hline $\begin{array}{l}\text { In general, my director/manager views me as ... } \\
\text { hard-working and motivated to do my best. } \\
\text { committed to my jobs. } \\
\text { honest and trustworthy. } \\
\text { a person with strong moral values. } \\
\text { committed to them as my manager/supervisor. } \\
\text { an individual whose actions reflect my beliefs. }\end{array}$ & Low $(n=47)$ & \multicolumn{2}{|c|}{$\begin{array}{c}\text { Spirituality Scor } \\
\text { Medium (n=86) } \\
\text { LS Mean } \pm \text { SE }\end{array}$} & \multicolumn{2}{|c|}{ High $(n=341)$} & \\
\hline Total Employee Trust Score $(E T S)^{\mathrm{c}}$ & $35.9 \pm 0.69$ & 36.1 & \pm 0.51 & 36.4 & \pm 0.26 & \\
\hline
\end{tabular}

${ }^{\mathrm{a}}$ Responses were based on a seven-point scale from 1-7 (1-strongly disagree to 7-strongly agree)

${ }^{\mathrm{b}}$ Spirituality Score range from 0-11 and is obtained by summing the results of the influence of religious/spiritual beliefs on

daily life (0-strongly disagree to 6-strongly agree) and frequency of prayer or meditation (0-never to 5-daily).

${ }^{\mathrm{d}}$ ETS: Represented the sum of all answer codes for the above questions from Section D answered by employees.

${ }^{0-4}$ LS Means with different superscripts for each Spirituality Score are significantly different from each other. ANOVA, p-value of at least 0.05 . 
Analysis of Variance of the ETS rated by the employee and the employees' Religiosity Score reflected an increase in ETS in those employees who had a Religiosity Score of 4 compared to employees who had a Religiosity Score of 0 and 3. Those with a Religiosity Score of 2 had a significantly higher ETS than did employees with a Score of 0 (Table 17). There were no differences found in ETS based on the Spirituality Score. A positive correlation was shown between the employee-rated ETS and their Religiosity Score $(\mathrm{R}-\mathrm{Sq}=0.10, \mathrm{p}<0.020)$, but no significant correlation was found between the employee-rated ETS and their Spirituality Score.

\section{Director-Rated Employees’ Trust by Directors' Religiosity and Spirituality Scores}

Generally, directors do not rate their employees' trustworthiness differently based on their own Religiosity and Spirituality Scores. There were a few differences as seen in Tables 19 and 20, but no consistently identified trend. Directors with the highest [4] or the lowest [0] Religiosity Scores perceived their employees as being more honest and trustworthy than did the directors who had Religiosity Scores of 1 or 2. Employees were rated as being individuals whose actions reflect their beliefs more often by those directors with a Religiosity Score of 3 or 4 over directors who had Scores of 1 or 2 . Directors with Religiosity Scores of 0 or 3 perceived their employees as being individuals with strong moral values more so than did directors with a Score of 1 . There were no differences found using ANOVA and Pearson's Correlation in the director-rated ETS and the directors' Religiosity Score (Table 19).

Directors with the high Spirituality Scores rated their employees as being individuals whose actions reflect their beliefs more frequently than did directors with low 
Table 19. Director-Rated Employees' Trust $^{\text {a }}$ by Directors' Religiosity Score

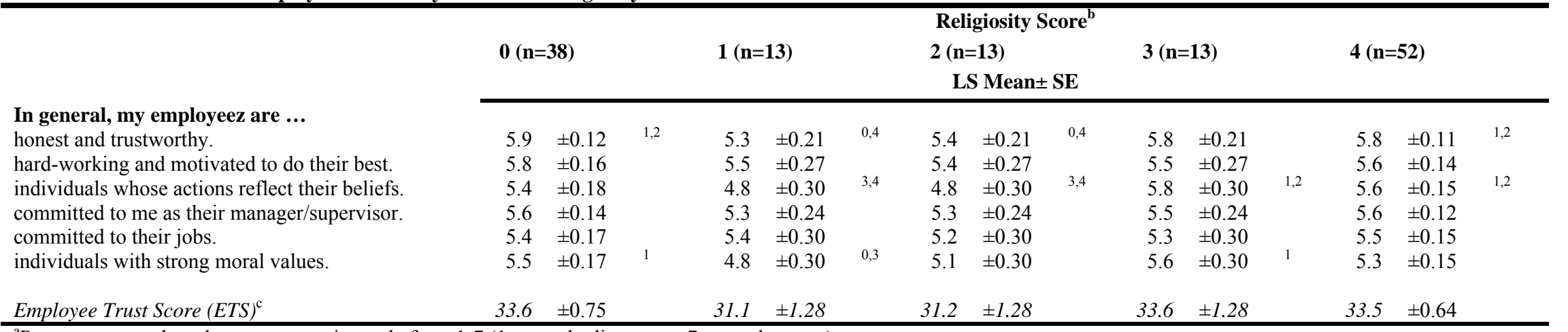

${ }^{\mathrm{a}}$ Responses were based on a seven-point scale from 1-7 (1-strongly disagree to 7-strongly agree).

${ }^{\mathrm{b}}$ Religiosity Score was given according to attendance of worship service in the past month. Scores ranged from 0-4 (0-no attendance to 4-four or more times).

${ }^{d}$ ETS: Represented the sum of all answer codes for the above questions from Section D answered by directors.

${ }^{0-4}$ LS Means with different superscripts for each Religiosity Score are significantly different from each other. ANOVA, $p$-value of at least 0.05 .

\section{Table 20. Director-Rated Employees’ Trust ${ }^{\mathrm{a}}$ by Directors' Spirituality Score}

\begin{tabular}{|c|c|c|c|c|c|c|c|c|}
\hline \multicolumn{3}{|c|}{ Low $(n=16)$} & \multicolumn{3}{|c|}{$\begin{array}{l}\text { Spirituality Score } \\
\text { Medium }(n=30) \\
\text { LS Mean } \pm \text { SE }\end{array}$} & \multicolumn{3}{|c|}{ High $(n=81)$} \\
\hline 5.8 & \pm 0.20 & & 5.5 & \pm 0.14 & & 5.8 & \pm 0.09 & \\
\hline 6.1 & \pm 0.24 & 2 & 5.2 & \pm 0.18 & 1,3 & 5.7 & \pm 0.11 & 2 \\
\hline 5.0 & \pm 0.28 & 3 & 5.1 & \pm 0.20 & 3 & 5.6 & \pm 0.12 & 1,2 \\
\hline 5.9 & \pm 0.21 & 2 & 5.3 & \pm 0.15 & 1 & 5.5 & \pm 0.09 & \\
\hline 5.9 & \pm 0.25 & 2 & 5.1 & \pm 0.18 & 1 & 5.5 & \pm 0.11 & \\
\hline 5.5 & \pm 0.27 & & 5.2 & \pm 0.20 & & 5.4 & \pm 0.12 & \\
\hline 34.2 & \pm 1.14 & 2 & 31.4 & \pm 0.83 & 1,3 & 33.5 & \pm 0.51 & 2 \\
\hline
\end{tabular}

${ }^{\mathrm{a}}$ Responses were based on a seven-point scale from 1-7 (1-strongly disagree to 7-strongly agree).

${ }^{\mathrm{b}}$ Religiosity Score was given according to attendance of worship service in the past month. Scores ranged from 0-4 (0-no attendance to 4-four or more times).

${ }^{\mathrm{d}}$ ETS: Represented the sum of all answer codes for the above questions from Section D answered by directors.

${ }^{0-4}$ LS Means with different superscripts for each Spirituality Score are significantly different from each other. ANOVA, $p$-value of at least 0.05 . 
or moderate Spirituality Scores. Directors with the lowest Spirituality Score thought that their employees were more committed to their jobs and to them as their supervisor than those directors at the moderate Spirituality Score level. Directors with moderate Spirituality Score were significantly less likely to perceive their employees as hardworking and motivated than those directors with low or high Spirituality Scores. Finally, there were significant differences between director-rated total ETS and Spirituality Score levels of the directors (Table 20). Directors with moderate spirituality rated total ETS less than those directors with a low or high spirituality.

\section{Employee Commitment}

When directors were asked about their employees' commitment to their jobs, $86.05 \%$ of directors had a high level of agreement that their employees were committed. Employees, however, thought their directors perceived them as being even more committed to their jobs $(95.05 \%)$. When employees were asked if they were considering a job change in the near future $16.2 \%$ agreed or strongly agreed. Based on employees' consideration for job change (question 68), it appears that directors perceived their employees as being more committed than they actually are $(\mathrm{t}=11.62, \mathrm{p}<0.0001)$. Also, employees think their directors perceive them as being more committed than they actually are $(\mathrm{t}=27.29, \mathrm{p}<0.0001)$.

Employees' commitment to their jobs was further explored comparing the employees' consideration of a job change in the near future (Question 68) to the employees' perception of their directors' trust level (employee-rated DTS). Using Pearson's Correlation, there was a negative correlation found between the employees' 
commitment and their trust for their director $(\mathrm{R}-\mathrm{Sq}=-0.36, \mathrm{p}<0.0001)$. Employees with the lowest commitment levels had the lowest levels of trust for their directors. 


\section{DISCUSSION/CONCLUSIONS}

Food service and nutrition directors and their employees are religious/spiritual people, generally. A larger majority of directors surveyed reported attending worship services at least four times the previous month than did their employees. However, a greater percentage of employees than directors were rated highly spiritual due to their increased frequency of prayer and daily influence of their religious and spiritual beliefs. Large percentages of both directors and employees were influenced at work by their religious and spiritual beliefs, and exhibited religious behavior in the workplace. Even though directors and employees appeared to be fairy religious/spiritual, and even brought those spiritual influences into their jobs, talking about their beliefs in the workplace was still rare. Based on these results, the first hypothesis is accepted which suggested that directors and employees that had higher Religiosity and Spirituality Scores would have a higher level of agreement regarding statements of the influence of spirituality on their workplace practices.

Hypothesis II expected directors that had higher Religiosity and Spirituality Scores to be perceived by their subordinates as having increased characteristics that promoted trust in the workplace. Contrary to what was hypothesized, there does not appear to be any correlation between the directors' religiosity and spirituality and their employee-rated trustworthiness. Therefore, the second hypothesis must be rejected. Hypothesis III anticipated that employees that had higher Religiosity and Spirituality Scores would be perceived by their directors as having increased characteristics that promote trust and commitment in the workplace. Reliable ANOVA and Pearson's Correlations for the director-rated trustworthiness and commitment of employees by the 
employees' Religiosity and Spirituality Scores could not be performed because each director rated multiple employees. Therefore, the third hypothesis can neither be accepted nor rejected. It is expected that the employees would mimic the directors and most likely would not have had a correlation between their religious/spiritual beliefs and their director-rated trustworthiness, but this could not be determined. As mentioned, there was not a validated measure of trust available to use in this study to measure the trustworthiness of directors and employees. Although this study measured trust using verified aspects and characteristics of trust, it is difficult to know if results are an actual reflection of trust.

Another aspect to consider is that because participants were, in general, highly religious and spiritual, the influence of their beliefs on trust may not have been differentiated. Though there was no significant correlation between trust and religiosity/spirituality, directors and employees did, generally, exhibit high levels of trustpromoting characteristics in the workplace. Again, it is questioned if the high degree of trust in this population may have hidden specific relationships between trust and religiosity/spirituality.

The majority of directors and employees believe others perceive them as being trustworthy or having trust-promoting characteristics. Directors and employees tend to over-rate their own trustworthiness when compared to ratings by their counterpart(s). Both trustworthy characteristics and actions were explored in the directors. Results illustrated that the employees' perceptions were lower (usually 10 percent), but most were not significantly lower regarding the directors' trustworthy characteristics than what the director thought the employees would perceive. Employee-ratings on the 
directors' trustworthy actions seen in the workplace were all significantly lower (20$25 \%$ ) than directors anticipated the employees would perceive. Even though employees rated their directors' trustworthiness significantly lower than directors thought they would, the majority of directors were still perceived as being highly trustworthy by their employees. Director and employee responses were in agreement on the fact that few directors disclose their most important values and beliefs while at work which is known to be a highly trust-promoting action $(6,9,47)$.

Over four-fifths of directors agreed that their employees are honest and trustworthy, hard-working and motivated to do their best, and committed to their jobs and to them as their director. As with the directors, there was a significant difference in how the employees expected their directors to perceive their trustworthiness and how the directors actually perceived them. Yet, differences in the individual employees' trust questions were less (less than 10\%) than those seen with directors' trust questions. However, there was a greater difference (greater than 10\%) found in directors' perception that their employees were people with strong moral values and what employees anticipated would be perceived by their directors. Also, directors expected their employees to be more committed to their jobs than they actually were. Interestingly, the employees even thought that their director would perceive them as being more committed than they really were. Those less committed employees (as measured by strongly considering a job change in the near future) trusted their directors less than did the more committed employees, as was expected based on the literature $(4,36,38)$.

Degree of religiosity and spirituality did not consistently affect the way directors and employees rated each others' trustworthiness, though it was related to how they 
perceived their own trustworthiness. Generally, as the directors' and employees' religiosity and spirituality increased, self-perceived trustworthiness also increased.

For the most part, those directors and employees who attended worship services more often were more likely to demonstrate specific spiritual actions and attitudes at work. Likewise, those directors and employees that frequently prayed and felt their religious beliefs/spirituality influenced their daily life were more likely to exhibit spiritual behaviors in the workplace. Even those directors and employees that attended worship services and prayed less often agreed that their religious/spiritual beliefs influenced their attitudes and actions in the workplace. Though there has been an unspoken rule that religion and spirituality remain compartmentalized from the workplace, these results suggest that directors and employees in hospital food and nutrition services do integrate their religious and spiritual beliefs in their daily work practices, so expecting separation would be futile. Spiritual influence on management and their subordinates in the workplace warrants further research.

\section{FURTHER RESEARCH}

In this study, commitment of employees was only based on their consideration of changing jobs in the near future job, and the influence of employees' religiosity and spirituality on commitment was not investigated. A study of employees' commitment

level, using a more complete, validated measure of commitment, would shed light on the effects of religious and spiritual beliefs on commitment in the workplace. Further investigation of trust compared to management and leadership styles would be another opportunity for research. 


\section{REFERENCES}

1. Kouzes JM, Posner BZ. The Jossey-Bass Academic Administrator's Guide to Exemplary Leadership. San Francisco, CA: Jossey-Bass Publishers; 2003.

2. Barker AM, Arensberg MBF, Schiller MR. Leadership in Dietetics: Achieving a Vision for the Future. Chicago, IL: The American Dietetic Association; 1994.

3. Davis JH, Schoorman FD, Mayer RC, Tan HH. The trusted general manager and business unit performance: empirical evidence of a competitive advantage. Strategic Manag J. 2000;21:563-576.

4. Laschinger HKS, Finegan J, Shamian J. The impact of workplace empowerment, organizational trust on staff nurses' work satisfaction and organizational commitment. Health Care Manag Rev. 2001;26(3):7-23.

5. Mishra AK, Spreitzer GM. Explaining how survivors respond to downsizing: the roles of trust, empowerment, justice, and work redesign. Acad Manag Rev. 1998;23:567-588.

6. Mishra J, Morrisey MA. Trust in employee/employer relationships: a survey of West Michigan managers. Public Personnel Manag. 1990;19:443-61.

7. Giffords ED, Dina RP. Changing organizational cultures: the challenge in forging successful mergers. Admin Soc Work. 2003;27:69-81.

8. Martins, N. A model for managing trust. Int J Manpower. 2002;23:754-769.

9. Rusaw AC. The ethics of leadership trust. Int J Organ Theory Behav. 2000;3:547-547.

10. Mayer RC, Davis JH, Schoorman FD. An integrative model of organizational trust. Acad Manag Rev. 1995;20:709-734.

11. Raths D. Bridging the generation gap. InfoWorld. 1999;21(45):84.

12. Tulgan B. Managing Generation X: How to Bring out the Best in Young Talent. Oxford: Capstone Publishing Limited; 1996.

13. Mitroff II, Denton EA. A Spiritual Audit of Corporate America: a Hard Look at Spirituality, Religion, and Values in the Workplace. San Francisco, CA: JosseyBass Inc.; 1999.

14. Keaveney SM. When MTV goes CEO: what happens when the unmanageable become managers? Marketing Manag. 1997;6(3):21-24. 
15. Laabs JJ. Balancing spirituality and work. Personnel J. 1995;74(9):60-69.

16. Gallup, Jr. G, Jones T. The Next American Spirituality: Finding God in the Twenty-First Century. Colorado Springs, CO: Cook Communications; 2000.

17. Digh P. Religion in the workplace: make a good-faith effort to accommodate. HR Magazine. 1998;43(13):84-91.

18. Conlin M. Religion in the workplace: the growing presence of spirituality in corporate America. Bus Week. 1999; Nov 1:150-158.

19. Skousen KM. The Effect of Religiosity and Spirituality on Work Practices of Dietitians in Management Roles. Provo, UT: Brigham Young University; 2001. Unpublished thesis.

20. Hill PC, Hood RW. Measures of Religiosity. Birmingham, AL: Religious Education Press; 1999.

21. Merriam-Webster Online Dictionary. $<$ http://www.m-w.com/dictionary.htm $>$

22. Nanus B. Visionary Leadership: Creating a Compelling Sense of Direction for Your Organization. San Francisco, CA: Jossey-Bass Inc; 1992.

23. Offermann LR, Hanges PJ, Day DV. Leaders, followers, and values: progress and prospects for theory and research. Leadership Q. 2001;12:129-131.

24. Patterson J, Kim P. The Day America Told the Truth. New York, NY: Penguin Books USA Inc.; 1992.

25. General Social Survey 2002 at $<$ http://www.thearda.com> April 2004.

26. Lombardi DN. Handbook for the New Health Care Manager. $2^{\text {nd }}$ ed. San Francisco, CA: Jossey-Bass Inc; 2001.

27. Caldwell C, Clapham SE. Organizational trustworthiness: an international perspective. J Bus Ethics. 2003;47:349-354.

28. Kreitner R, Kinicki A. Organizational Behavior. $2^{\text {nd }}$ ed. Homewood, IL: Irwin, Inc.; 1992.

29. Carnevale DG. Trustworthy Government: Leadership and Management Strategies for Building Trust and High Performance. San Francisco, CA: JosseyBass Publishers; 1995.

30. Ouchi WG. Theory Z: How American Business can meet the Japanese Challenge. Boston, MA: Addison \& Wesley; 1981. 
31. Likert R, Likert JG. New Ways of Managing Conflict. New York: McGraw Hill; 1976.

32. Maslow A. Motivation and Personality. $2^{\text {nd }}$ ed. New York: Harper \& Row; 1970.

33. Hart KM, Capps HR, Cangemi JP, Cillouet LM. Exploring organizational trust and its multiple dimension: a case study of General Motors. Organ Dev J. 1986;4(2):31-39.

34. Cangemi JP, Rice J, Kowalski CJ. The development, decline and renewal of trust in an organization: some observations. Organ Dev J. 1998;7(4):2-9.

35. Hunter J. Good ethics means good business. Can Bus Rev. 1996;23(1):14-17.

36. Podsakoff PM, MacKenzie SB, Bommer WH. Transformational leadership behaviors and substitutes for leadership as determinants of employee satisfaction, commitment, trust, and organizational citizenship behaviors. J Manag. 1996;22:259-98.

37. Mellinger GD. Interpersonal trust as a factor in communication. J Abnormal Social Psychol. 1956;52:302-309.

38. Kanter RM. Men and Women of the Corporation. $2^{\text {nd }}$ ed. New York: Basic Books, 1993.

39. Zand DE. Trust and managerial problem solving. Admin Sci Q. 1972;17:229239.

40. Argyris C. Integrating the Individual and the Organization. New York, NY: John Wiely \& Sons, Inc.; 1964.

41. Porter LW, Steers RM, Mowday RT, Boulian PV. Organizational commitment, job satisfaction, and turnover among psychiatric technicians. J Appl Psychol. 1974;59:603-609.

42. Angle $\mathrm{H}$ and Perry J. An empirical assessment of organizational commitment and organizational effectiveness. Admin Sci Q. 1981;26:1-14.

43. Meyer JP, Allen NJ. A three-component conceptualization of organizational commitment. Hum Resource Manag Rev. 1991;1:61-89.

44. Sims RL, Kroeck KG. The influence of ethical fit on employee satisfaction, commitment, and turnover. J Bus Ethics. 1994;13:939-947. 
45. Meyer JP, Paunonen SV, Gellatly IR, Goffin RD, Jackson DN. Organizational commitment and job performance: it's the nature of commitment that counts. J Appl Psychol. 1989;74:152-156.

46. Denhardt RB, Denhardt JV, Aristigueta MP. Managing Human Behavior in Public and Nonprofit Organizations. Thousand Oaks, CA: Sage Publications; 2002.

47. Kouzes JM, Posner BZ. The Leadership Challenge: How to Get Extraordinary Things Done in Organizations. San Francisco, CA: Jossey-Bass Publishers; 1995.

48. Hosmer LT. Trust: the connecting link between organizational theory and philosophical ethics. Acad Manag Rev. 1995;20:379-403.

49. Garcia-Zamor JC. Workplace spirituality and organizational performance. Public Admin Rev. 2003;63(3):355-363.

50. Mertzman R, Madsen P. Ethical Issues in Professional Life: A Multimedia Course. Lincoln, NE: University of Nebraska-Lincoln; 1992.

51. Littman M, ed. A Statistical Portrait of the US: Social Conditions and Trends. Lanham, MD: Bernan Press; 1998.

52. Kantor J, Weisber J. Ethical attitudes and ethical behavior: are managers role models? Int J Manpower. 2002;23:687-703.

53. Jones GE, Kavanagh MJ. An experimental examination of the effects of individual and situational factors on unethical behavioral intentions in the workplace. J Bus Ethics. 1996;15:511-523.

54. Carroll JW, Johnson DW, Marty ME. Religion in America: 1950 to the Present. San Francisco, CA: Harper \& Row, publishers; 1979.

55. Gallup, Jr. G, Jones S. 100 Questions and Answers: Religion in America. Princeton, NJ: The Princeton Religion Research Center; 1989.

56. Suziedelis A and Potvin RH. Sex differences in factors affecting religiousness among Catholic adolescents. J Scientific Study Religion. 1981;20:38-50.

57. Luckmann T. The Invisible Religion. New York, NY:Macmillan; 1967.

58. Martin D. A Sociology of English Religion. London: SCM Press; 1967.

59. de Vaus DA and McAllister I. Gender differences in religion: A test of the structural location theory. American Sociological Rev. 1987;52:472-281. 
60. de Vaus, DA. Workforce participation and sex differences in church attendance. Rev Religious Research. 1984;25:247-258.

61. Argue A, Johnson DR, White LK. Age and religiosity: evidence from a threewave panel analysis. J Scientific Study Religion. 1999;38:423-435.

62. Gallup, Jr. G, Poling D. The Search for America's Faith. Nashville, TE: Parthenon Press; 1980.

63. Gallup, Jr. GH, Bezilla R. The Religious Life of Young Americans. Princeton, NJ: The George H. Gallup International Institute; 1992.

64. Greeley AM. The Young Catholic Family: Religious Images and Marital Fulfillment. Chicago, IL: Thomas More Press; 1980.

65. Caplovitz D, Sherrow F. The Religious Drop-Outs: Apostasy among College Graduates. Beverly Hills, CA: Sage Publications; 1977.

66. Stark R. On the incompatibility of religion and science: a survey of American graduate students. J Scientific Study Religion. 1963;3:3-20.

67. Wadsworth MEJ, Freeman SR. Generation differences in beliefs: a cohort study of stability and change in religious beliefs. Br J Sociology. 1983;34:416-437.

68. Roor WC, Hadaway CK. Denominational switching in the seventies: going beyond Stark and Glock. J Scientific Study Religion. 1979;18:363-379.

69. Greeley A. Comment on Strark's "on the incompatibility of religion and science." J Scientific Study Religion. 1964;3:239-240.

70. Zelan, J. Religious apostasy, higher education, and occupational choices. Sociology Educ. 1968;41:370-379.

71. Merrill RM, Lyon JL, Jensen WJ. Lack of a secularizing influence of education on religious activity and parity among Mormons. J Scientific Study Religion. 2003;42:113-124.

72. Loury LD. Does church attendance really increase schooling? J Scientific Study Religion. 2004;43:119-127.

73. Cash KC, Gray GR. A framework for accommodating religion and spirituality in the workplace. Acad Manag Executive. 2000;14(3):124-134.

74. Bruce WM. Public administrator attitudes about spirituality: an exploratory study. Am Rev Public Admin. 2000;30:460-472. 
75. Niemiec S. Finding common ground for all ages. Security Distributing and Marketing. 2000;30(3):81-84.

76. Hui-Chun Y, Miller P. Then generation gap and cultural influence- a Taiwan empirical investigation. Cross Cultural Manag. 2003;10(3):23-41.

77. Leung J, Mertens B, Jordan T, Nakada G, Irwin J. Brave new material world? Asian Bus. 2000;36(1):16-17.

78. Maslow A. A theory of human motivation. Psychol Rev. 1943;50:370-396.

79. Goble FG. The Third Force: The Psychology of Abraham Maslow. New York, NY: Pocket Book; 1971.

80. Herzberg F. Work and the Nature of Man. New York: World Publishing Co.; 1966.

81. Vroom V. Work and Motivation. New York: John Wiley; 1964.

82. Porter L, Lawler E. Managerial Attitudes and Performance. Homewood, IL: Irwin; 1968.

83. Biesemeier C, Marino L, Schofield MK. Connective Leadership: Linking Vision with Action. Chicago, IL: American Dietetic Association; 2000.

84. Tom V. The role of personality and organizational images in the recruiting process. Organ Behav Hum Perf. 1971;6:573-592.

85. Caldwell D, O'Reilly C. Measuring person-job fit using profile comparison process. J Appl Psychol. 1990;75:648-657.

86. Downey H, Hellriegel D, Slocum J. Congruence between individual needs, organizational climate, job satisfaction, and performance. Acad Manag J. $1975 ; 18: 149-154$.

87. O'Reilly CA. Personality-job fit: implications for individual attitudes and performance. Organ Behav Hum Perf. 1977;18:36-46.

88. O'Reilly CA, Chatman J, Caldwell DF. People and organizational culture: a profile comparison approach to assessing person-organization fit. Acad Manag J. 1991;34:487-516.

89. Pervin LA. Performance and satisfaction as a function of individual environment fit. Psychol Bull. 1968;69:56-68.

90. Schneider B. The people make the place. Personnel Psychol. 1987;40:437-453. 
91. Cascio WF. Costing Human Resources: The financial Impact of Behavior in Organizations. $2^{\text {nd }}$ ed. Boston, MA:PWS-Kent Publishing Company; 1987.

92. Bass B, Avolio B. Multifactor Leadership Questionnaire Form 5X-Short. Mind Garden Inc; 2000. 
Appendix A

Director Questionnaire 


\section{Use the following scale to answer the questions in Sections A through D.}

Circle the appropriate number.

\begin{tabular}{|ccccccc|}
\hline $\begin{array}{c}\text { Strongly } \\
\text { Disagree }\end{array}$ & Disagree & $\begin{array}{c}\text { Somewhat } \\
\text { Disagree }\end{array}$ & $\begin{array}{c}\text { Neither Agree } \\
\text { or Disagree }\end{array}$ & $\begin{array}{c}\text { Somewhat } \\
\text { Agree }\end{array}$ & $\begin{array}{c}\text { Agree } \\
\text { Strongly } \\
\text { Agree }\end{array}$ \\
1 & 2 & 3 & 4 & 5 & 6 & 7 \\
\hline
\end{tabular}

\section{A. My religious beliefs/spirituality...}

1. ...guide my interactions with coworkers.

$\begin{array}{lllllll}1 & 2 & 3 & 4 & 5 & 6 & 7\end{array}$

2. ...help me deal with stressful situations.

$\begin{array}{lllllll}1 & 2 & 3 & 4 & 5 & 6 & 7\end{array}$

3. ...drive my work ethic.

4. ...guide decisions I make at work.

5. ... influence my commitment to my job and to my coworkers.

6. ....influence how I establish and follow company policies and procedures.

$\begin{array}{lllllll}1 & 2 & 3 & 4 & 5 & 6 & 7\end{array}$

7. ...influence my individual goals as a manager.

8. ....are apparent to those with whom I work.

$\begin{array}{lllllll}1 & 2 & 3 & 4 & 5 & 6 & 7\end{array}$

9. ...supply me with wisdom/insight in adapting to conditions in the workplace.

$\begin{array}{lllllll}1 & 2 & 3 & 4 & 5 & 6 & 7\end{array}$

$\begin{array}{lllllll}1 & 2 & 3 & 4 & 5 & 6 & 7\end{array}$

$\begin{array}{lllllll}1 & 2 & 3 & 4 & 5 & 6 & 7\end{array}$

$\begin{array}{lllllll}1 & 2 & 3 & 4 & 5 & 6 & 7\end{array}$

10. ... are a normal part of my discussions with coworkers.

11. ... are critical in helping me get through each workday.

$\begin{array}{lllllll}1 & 2 & 3 & 4 & 5 & 6 & 7\end{array}$

$\begin{array}{lllllll}1 & 2 & 3 & 4 & 5 & 6 & 7\end{array}$

$\begin{array}{lllllll}1 & 2 & 3 & 4 & 5 & 6 & 7\end{array}$

\section{B. I often...}

12. ...pray about work-related issues.

13. ...have spiritual/religious feelings at work.

$\begin{array}{lllllll}1 & 2 & 3 & 4 & 5 & 6 & 7\end{array}$

14. ... follow God's (a Supreme Being's) example in my interactions a work.

$\begin{array}{lllllll}1 & 2 & 3 & 4 & 5 & 6 & 7\end{array}$

15. ... rely on spiritual insight in making decisions at work.

$\begin{array}{lllllll}1 & 2 & 3 & 4 & 5 & 6 & 7\end{array}$

$\begin{array}{lllllll}1 & 2 & 3 & 4 & 5 & 6 & 7\end{array}$

\section{In general, my employees view me as...}

16. ...f fair.

17. ...easily approachable.

18. ...honest and trustworthy.

19. ....a person whose actions reflect my beliefs.

$\begin{array}{lllllll}1 & 2 & 3 & 4 & 5 & 6 & 7 \\ 1 & 2 & 3 & 4 & 5 & 6 & 7 \\ 1 & 2 & 3 & 4 & 5 & 6 & 7 \\ 1 & 2 & 3 & 4 & 5 & 6 & 7\end{array}$

\section{In general, my employees are...}

20. ...honest and trustworthy.

21. ... individuals whose actions reflect their beliefs.

22. ... individuals with strong moral values.

23. ...committed to their jobs.

24. ...committed to me as their manager/supervisor.

25. ... hard-working and motivated to do their best.

$\begin{array}{lllllll}1 & 2 & 3 & 4 & 5 & 6 & 7 \\ 1 & 2 & 3 & 4 & 5 & 6 & 7 \\ 1 & 2 & 3 & 4 & 5 & 6 & 7 \\ 1 & 2 & 3 & 4 & 5 & 6 & 7 \\ 1 & 2 & 3 & 4 & 5 & 6 & 7 \\ 1 & 2 & 3 & 4 & 5 & 6 & 7\end{array}$




\section{E. Use the following scale to rate how frequently the following statements fit you... (The word "others" may mean your peers, clients, direct reports, supervisors, and/or all of these individuals.) Circle the appropriate number.}

\begin{tabular}{|ccccc|}
\hline Not at all & Once in a while & Sometimes & Fairly often & $\begin{array}{c}\text { Frequently, if not } \\
\text { always } \\
0\end{array}$ \\
1 & 2 & 3 & 4 \\
\hline
\end{tabular}

26. I provide others with assistance in exchange for their efforts

$\begin{array}{lllll}0 & 1 & 2 & 3 & 4 \\ 0 & 1 & 2 & 3 & 4 \\ 0 & 1 & 2 & 3 & 4 \\ 0 & 1 & 2 & 3 & 4 \\ 0 & 1 & 2 & 3 & 4 \\ 0 & 1 & 2 & 3 & 4 \\ 0 & 1 & 2 & 3 & 4 \\ 0 & 1 & 2 & 3 & 4 \\ 0 & 1 & 2 & 3 & 4 \\ 0 & 1 & 2 & 3 & 4 \\ 0 & 1 & 2 & 3 & 4 \\ 0 & 1 & 2 & 3 & 4 \\ 0 & 1 & 2 & 3 & 4 \\ 0 & 1 & 2 & 3 & 4 \\ 0 & 1 & 2 & 3 & 4 \\ 0 & 1 & 2 & 3 & 4 \\ 0 & 1 & 2 & 3 & 4 \\ 0 & 1 & 2 & 3 & 4 \\ 0 & 1 & 2 & 3 & 4 \\ 0 & 1 & 2 & 3 & 4 \\ 0 & 1 & 2 & 3 & 4 \\ 0 & 1 & 2 & 3 & 4 \\ 0 & 1 & 2 & 3 & 4 \\ 0 & 1 & 2 & 3 & 4 \\ 0 & 1 & 2 & 3 & 4 \\ 0 & 1 & 2 & 3 & 4 \\ 0 & 1 & 2 & 3 & 4 \\ 0 & 1 & 2 & 3 & 4 \\ 0 & 1 & 2 & 3 & 4 \\ 0 & 1 & 2 & 3 & 4 \\ 0 & 1 & 2 & 3 & 4 \\ 0 & 1 & 2 & 3 & 4\end{array}$

27. I re-examine critical assumptions to question whether they are appropriate

28. I fail to interfere until problems become serious

29. I focus attention on irregularities, mistakes, exceptions, and deviations from standards

30. I talk about my most important values and beliefs

31. I seek differing perspectives when solving problems

32. I talk optimistically about the future

33. I instill pride in others for being associated with me

34. I discuss in specific terms who is responsible for achieving performance objectives

35. I wait for things to go wrong before taking action

36. I talk enthusiastically about what needs to be accomplished

37. I specify the importance of having a strong sense of purpose

38. I spend time teaching and coaching

39. I make clear what one can expect to receive when performance goals are achieved

40. I show that I am a firm believer in "if it ain't broke, don't fix it."

41. I go beyond self-interest for the good of the group

42. I treat others as individuals rather than just a member of the group

43. I demonstrate that problems must become chronic before I take action

44. I act in ways that build others' respect for me

45. I concentrate my full attention on dealing with mistakes, complaints, and failures

46. I consider the moral and ethical consequences of decisions

47. I keep track of all mistakes

48. I display a sense of power and confidence

49. I articulate a compelling vision of the future

50. I direct my attention toward failures to meet standards

51. I consider an individual as having different needs, abilities, and aspirations from others

52. I get others to look at problems from many different angles

53. I help others develop their strengths

54. I suggest new ways of looking at how to complete assignments

55. I emphasize the importance of having a collective sense of mission

56. I express satisfaction when others meet expectations

57. I express confidence that goals will be achieved

Source of questions 26-57: Multifactor Leadership Questionnaire Form 5X-Short. (C) Copyright 1995, 2000 by Bernard Bass and Bruce Avolio. Adapted with permission. Published by Mind Garden Inc. All rights reserved. 


\section{F. About you...}

Check $\boldsymbol{V}$ the box of the appropriate answer

58. Ethnic group:

- African American

- Asian and Pacific Islander

a Caucasian

a Native American

口 Other (Specify)

59. Gender:

a Female a Male

60. Age:

๑ 21-30 a 41-50 a $\geq 61$

๑ $31-40$ व $51-60$

61. Level of education:

- Associate Degree

- Bachelor's Degree

- Master's Degree

a Some post grad, but no degree

a Doctoral degree

Degree area:

62. What is your job title?

63. Your pay/salary:

- 10-19,000/year

a 20-30,000/year

- 31-40,000/year

\ 41-50,000/year

a 61-70,000/year

a $>70,000 /$ year

64. How many hours do you work each week?

Is this considered:

a Full time

๖ Part time

65. In general, I enjoy my role as a

director/manager.

\ Strongly agree

a Agree

- Somewhat agree

a Neither agree or disagree

- Somewhat disagree

a Disagree

- Strongly disagree
66. Time period in current position:

\begin{tabular}{|c|c|c|}
\hline less than one year & ם & $9-11$ years \\
\hline 1-2 years & ם & $12-14$ years \\
\hline $3-5$ years & ם & $\geq 15$ years \\
\hline
\end{tabular}

67. Total time in all management positions:

a less than one year

a 1-5 years

a 6-10 years

a 11-20 years

a more than 20 years

68. Were you...

口 hired to your current position from outside the hospital.

a promoted from within the hospital to your current position.

69. In the past month, how many times have you attended worship services (if never, enter $0)$ ?

70. What is your religious preference?

\begin{tabular}{llll}
$\square$ & Atheist & $\square$ & Muslim \\
$\square$ & Buddhist & $\square$ & Protestant \\
$\square$ & Catholic & $\square$ & Jewish \\
$\square$ & Hindu & $\square$ & None \\
$\square$ & Other & & \\
\hline
\end{tabular}

71. My religious/spiritual beliefs influence my daily life:

a Strongly agree

a Agree

a Somewhat agree

a Neither agree or disagree

a Somewhat disagree

a Disagree

․ Strongly disagree

72. How often do you pray or meditate?

口 Daily

\ Most days

口 Once or twice a week

a A few times a month

a Seldom

a Never

Thank you for your assistance. 
Appendix B

Employee Questionnaire 


\section{Use the following scale to answer the questions in Section A through D. Circle the appropriate number.}

\begin{tabular}{|c|c|c|c|c|c|c|}
\hline $\begin{array}{c}\text { Strongly } \\
\text { Disagree } \\
1\end{array}$ & $\begin{array}{c}\text { Disagree } \\
2\end{array}$ & $\begin{array}{c}\text { Somewhat } \\
\text { Disagree } \\
3\end{array}$ & $\begin{array}{c}\text { Neither Agree } \\
\text { or Disagree } \\
4\end{array}$ & $\begin{array}{c}\text { Somewhat } \\
\text { Agree } \\
5\end{array}$ & $\begin{array}{c}\text { Agree } \\
6\end{array}$ & $\begin{array}{c}\text { Strongly } \\
\text { Agree } \\
7\end{array}$ \\
\hline
\end{tabular}

\section{A. My religious beliefs/spirituality...}

1. ...guide my interactions with coworkers.

2. ...help me deal with stressful situations.

3. ...drive my work ethic.

4. ...guide decisions I make at work.

5. ...influence my commitment to my job and to my coworkers.

6. ...influence how I follow company policies and procedures.

7. ...influence my individual goals as an employee.

8. ....are apparent to those with whom I work.

...supply me with wisdom/insight in adapting to

9. conditions in the workplace.

10. ... are a normal part of my discussions with coworkers.

11. ... are critical in helping me get through each workday. $\begin{array}{lllllll}1 & 2 & 3 & 4 & 5 & 6 & 7\end{array}$

$\begin{array}{lllllll}1 & 2 & 3 & 4 & 5 & 6 & 7\end{array}$

$\begin{array}{lllllll}1 & 2 & 3 & 4 & 5 & 6 & 7\end{array}$

$\begin{array}{lllllll}1 & 2 & 3 & 4 & 5 & 6 & 7\end{array}$

$\begin{array}{lllllll}1 & 2 & 3 & 4 & 5 & 6 & 7\end{array}$

$\begin{array}{lllllll}1 & 2 & 3 & 4 & 5 & 6 & 7\end{array}$

$\begin{array}{lllllll}1 & 2 & 3 & 4 & 5 & 6 & 7\end{array}$

$\begin{array}{lllllll}1 & 2 & 3 & 4 & 5 & 6 & 7\end{array}$

$\begin{array}{lllllll}1 & 2 & 3 & 4 & 5 & 6 & 7\end{array}$

$\begin{array}{lllllll}1 & 2 & 3 & 4 & 5 & 6 & 7\end{array}$

$\begin{array}{lllllll}1 & 2 & 3 & 4 & 5 & 6 & 7\end{array}$

\section{B. I often...}

12. ...pray about work-related issues.

13. ...have spiritual/religious feelings at work.

$\begin{array}{lllllll}1 & 2 & 3 & 4 & 5 & 6 & 7\end{array}$

14. ... follow God's (a Supreme Being's) example in my interactions a work.

$\begin{array}{lllllll}1 & 2 & 3 & 4 & 5 & 6 & 7\end{array}$

15. ...rely on spiritual insight in making decisions at work.

\section{In general, my director/manager is...}

16. ...fair.

17. ...easily approachable.

18. ...honest and trustworthy.

19. ...a person whose actions reflect his/her beliefs.

$\begin{array}{lllllll}1 & 2 & 3 & 4 & 5 & 6 & 7 \\ 1 & 2 & 3 & 4 & 5 & 6 & 7 \\ 1 & 2 & 3 & 4 & 5 & 6 & 7 \\ 1 & 2 & 3 & 4 & 5 & 6 & 7\end{array}$

\section{In general, my director/manager views me as...}

20. ...honest and trustworthy.

$\begin{array}{lllllll}1 & 2 & 3 & 4 & 5 & 6 & 7 \\ 1 & 2 & 3 & 4 & 5 & 6 & 7 \\ 1 & 2 & 3 & 4 & 5 & 6 & 7 \\ 1 & 2 & 3 & 4 & 5 & 6 & 7 \\ 1 & 2 & 3 & 4 & 5 & 6 & 7 \\ 1 & 2 & 3 & 4 & 5 & 6 & 7\end{array}$




\section{E. Use the following scale to rate how frequently the following statements describe your Director/Manager...}

\begin{tabular}{|ccccc|}
\hline Not at all & Once in a while & Sometimes & Fairly often & $\begin{array}{c}\text { Frequently, if not } \\
\text { always } \\
0\end{array}$ \\
1 & 2 & 3 & 4 \\
\hline
\end{tabular}

26. Provides me with assistance in exchange for my efforts

27. Re-examines critical assumptions to question whether they are appropriate

28. Fails to interfere until problems become serious

$\begin{array}{lllll}0 & 1 & 2 & 3 & 4\end{array}$

29. Focuses attention on irregularities, mistakes, exceptions, and deviations from standards

30. Talks about their most important values and beliefs

31. Seeks differing perspectives when solving problems

32. Talks optimistically about the future

33. Instills pride in me for being associated with him/her

34. Discusses in specific terms who is responsible for achieving performance objectives

35. Waits for things to go wrong before taking action

36. Talks enthusiastically about what needs to be accomplished

37. Specifies the importance of having a strong sense of purpose

38. Spends time teaching and coaching

39. Makes clear what one can expect to receive when performance goals are achieved

40. Shows that he/she is a firm believer in "if it ain't broke, don't fix it."

41. Goes beyond self-interest for the good of the group

42. Treats me as an individual rather than just a member of the group

43. Demonstrates that problems must become chronic before taking action

44. Acts in ways that build my respect

45. Concentrates his/her full attention on dealing with mistakes, complaints, and failures

$\begin{array}{lllll}0 & 1 & 2 & 3 & 4\end{array}$

$\begin{array}{lllll}0 & 1 & 2 & 3 & 4\end{array}$

46. Considers the moral and ethical consequences of decisions

47. Keeps track of all mistakes

48. Displays a sense of power and confidence

$\begin{array}{lllll}0 & 1 & 2 & 3 & 4\end{array}$

$\begin{array}{lllll}0 & 1 & 2 & 3 & 4\end{array}$

$\begin{array}{lllll}0 & 1 & 2 & 3 & 4\end{array}$

$\begin{array}{lllll}0 & 1 & 2 & 3 & 4\end{array}$

$\begin{array}{lllll}0 & 1 & 2 & 3 & 4\end{array}$

$\begin{array}{lllll}0 & 1 & 2 & 3 & 4\end{array}$

$\begin{array}{lllll}0 & 1 & 2 & 3 & 4\end{array}$

$\begin{array}{lllll}0 & 1 & 2 & 3 & 4\end{array}$

$\begin{array}{lllll}0 & 1 & 2 & 3 & 4\end{array}$

$\begin{array}{lllll}0 & 1 & 2 & 3 & 4\end{array}$

$\begin{array}{lllll}0 & 1 & 2 & 3 & 4\end{array}$

$\begin{array}{lllll}0 & 1 & 2 & 3 & 4\end{array}$

$\begin{array}{lllll}0 & 1 & 2 & 3 & 4\end{array}$

$\begin{array}{lllll}0 & 1 & 2 & 3 & 4\end{array}$

$\begin{array}{lllll}0 & 1 & 2 & 3 & 4\end{array}$

$\begin{array}{lllll}0 & 1 & 2 & 3 & 4\end{array}$

$\begin{array}{lllll}0 & 1 & 2 & 3 & 4\end{array}$

49. Articulates a compelling vision of the future

50. Directs my attention toward failures to meet standards

51. Considers me as having different needs, abilities, and aspirations from others

$\begin{array}{lllll}0 & 1 & 2 & 3 & 4\end{array}$

$\begin{array}{lllll}0 & 1 & 2 & 3 & 4\end{array}$

$\begin{array}{lllll}0 & 1 & 2 & 3 & 4\end{array}$

$\begin{array}{lllll}0 & 1 & 2 & 3 & 4\end{array}$

52. Gets me to look at problems from many different angles

$\begin{array}{lllll}0 & 1 & 2 & 3 & 4\end{array}$

53. Helps me to develop my strengths

$\begin{array}{lllll}0 & 1 & 2 & 3 & 4\end{array}$

54. Suggests new ways of looking at how to complete assignments

$\begin{array}{lllll}0 & 1 & 2 & 3 & 4\end{array}$

55. Emphasizes the importance of having a collective sense of mission

$\begin{array}{lllll}0 & 1 & 2 & 3 & 4\end{array}$

56. Expresses satisfaction when I meet expectations

$\begin{array}{lllll}0 & 1 & 2 & 3 & 4\end{array}$

57. Expresses confidence that goals will be achieved Bruce Avolio. Adapted with permission. Published by Mind Garden Inc. All rights reserved. 


\section{F. About you...}

\section{Check $\checkmark$ the box of the appropriate answer.}

58. Ethnic group:

African American

a Asian and Pacific Islander

- Caucasian

- Native American

口 Other (Specify)

59. Gender:

๖ Female a Male

60. Age:

a 18-20 31-40 a $51-60$

व 21-30 4 4 4 a $\geq 61$

61. Level of education:

a High School Diploma or GED

․ Associate Degree

a Bachelor's Degree

a Master's Degree

a Some post grad, but no degree

a Doctoral degree

If degree, area:

62. What is your job title?

63. Your pay/Salary:

- 10-19,000/year

a 20-30,000/year

a 31-40,000/year

a 41-50,000/year

a 61-70,000/year

a >70,000/year

64. How many hours do you work each week?

Is this considered:

a Full time

๑ Part time

65. In general, I enjoy my current job.

a Strongly agree

a Agree

ป Somewhat agree

a Neither agree or disagree

๖ Somewhat disagree

a Disagree

a Strongly disagree
66. Time period in current position:

a less than one year a 9-11 years

a 1-2 years a 12-14 years

व 3-5 years $\square \geq 15$ years

a 6-8 years

67. Time period you have worked with your current manager?

a less than one year

a 1-5 years

a 6-10 years

व 11-20 years

a more than 20 years

68. I am considering a job change in the near future.

․ Strongly agree

๑ Agree

a Somewhat agree

口 Neither agree or disagree

\ Somewhat disagree

- Disagree

๑ Strongly disagree

69. In the past month, how many times have you attended worship services (if never, enter $0)$ ?

70. What is your religious preference?

a Atheist a Muslim

a Buddhist a Protestant

๑ Catholic a Jewish

a Hindu a None

व Other

71. My religious/spiritual beliefs influence my daily life.

๑ Strongly agree

- Agree

口 Somewhat agree

a Neither agree or disagree

口 Somewhat disagree

a Disagree

a Strongly disagree

72. How often do you pray or meditate?

a Daily

- Most days

- Once or twice a week

口 A few times a month

a Seldom

口 Never

Thank you for your assistance. 
Appendix C

Initial Request

-Director Request Letter

-Director Request Postcard

-Clinical Nutrition Manager Request Letter

-Clinical Nutrition Manager Request Postcard 

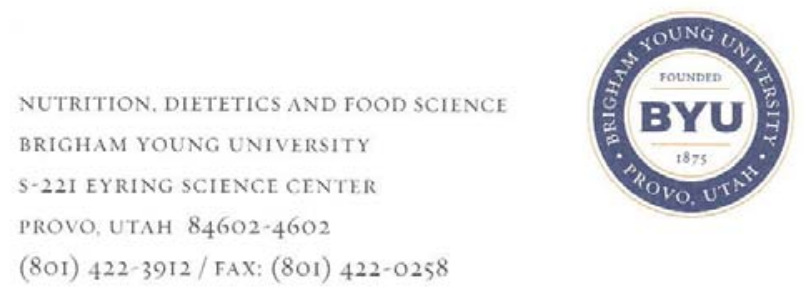

Director of Food and Nutrition Services

October 2, 2003

Dear Director of Food and Nutrition Services:

Management is a complex and challenging task. One aspect of management that has received quite a bit of recent attention in popular management literature is spirituality. However, little research has been done in this area. We are investigating the impact of religiosity/spirituality on workplace relationships of foodservice and nutrition managers and those whom they supervise.

Your hospital has been selected for participation in this study from the American Hospital Association database. Our study is designed for participation from the following:

- Directors of Food and Nutrition Services and those under their direct supervision.

[i.e. foodservice managers/supervisors, dietitians, and diet techs (who do not report to a clinical nutrition manager)] and,

- Clinical Nutrition Managers (where applicable) and those directly under their supervision (i.e. dietitians, diet techs, etc.).

In order to obtain data representative of Directors in Food and Nutrition Services, Clinical Nutrition Managers, and their subordinates, we need your participation.

This study has been approved by the Institutional Review Board (IRB) at Brigham Young University. If you have questions about your rights as a participant, you may call Shane Schulthies, Chair of the IRB at (801) 4225490. There are no known risks or discomforts associated with participation. Only combined results will be reported; individual responses will be kept confidential.

1. Please fill out and return the enclosed postage paid blue postcard. If your facility also has a clinical nutrition manager, please give the separate letter and postcard (gold) to him/her to fill out.

If willing to participate, once the postcard has been returned:

2. You and your clinical nutrition manger will then promptly receive separate packets containing surveys and business reply envelopes for yourselves and those whom you directly supervise.

3. Distribute surveys.

4. Participants fill out the surveys and return them in the individual business reply envelopes provided. Surveys should take approximately 10 minutes to complete.

Please take a few minutes to fill out the postcard and return by October 17, 2003. The results of this study may shed light on aspects of management that have been largely unexamined. We appreciate your assistance and look forward to receiving your postcard.

Sincerely,

Anna Sarver

Graduate Student
Jennifer Oler, RD, CD

Graduate Student
Nora Nyland, PhD, RD, CD 


\section{Director of Food and Nutrition Services Survey Participation Postcard}

\section{Name:}

Job Title:

Hospital:

\# Beds:

Work Address:

City: State:

Zip:

Email:

Are you willing to participate in this survey?

$$
\text { (If yes, subsequent mailings will be sent directly to you.) }
$$

How many of each of the following do you directly supervise?

a. Foodservice managers/supervisors:

b. Clinical dietitians: Diet techs: (list only if they do not report to a clinical nutrition manager).

$\square \quad$ There is not a separate clinical nutrition manager at my facility.

Thank you for your response. Please fill out and return this postcard by October 17, 2003. 
NUTRITION, DIETETICS AND FOOD SCIENCI

BRIGHAM YOUNG UNIVERSITY

S-22I EYRING SCIENCE CENTER

PROVO, UTAH 84602-4602

(8OI) 422-3912/FAX: (8OI) 422-0258

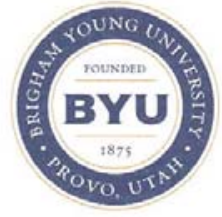

\section{Clinical Nutrition Manager}

October 2, 2003

Dear Clinical Nutrition Manager:

Management is a complex and challenging task. One aspect of management that has received quite a bit of recent attention in popular management literature is spirituality. However, little research has been done in this area. We are investigating the impact of religiosity/spirituality on workplace relationships of foodservice and nutrition managers and those whom they supervise.

Your hospital has been selected for participation in this study from the American Hospital Association database. Our study is designed for participation from the following:

- Directors of Food and Nutrition Services and those under their direct supervision. [i.e. foodservice managers/supervisors, dietitians, and diet techs (who do not report to a clinical nutrition manager)] and,

- Clinical Nutrition Managers (where applicable) and those directly under their supervision (i.e. dietitians, diet techs, etc.).

In order to obtain data representative of Directors in Food and Nutrition Services, Clinical Nutrition Managers, and their subordinates, we need your participation.

This study has been approved by the Institutional Review Board (IRB) at Brigham Young University. If you have questions about your rights as a participant, you may call Shane Schulthies, Chair of the IRB at (801) 4225490. There are no known risks or discomforts associated with participation. Only combined results will be reported; individual responses will be kept confidential.

1. As clinical nutrition manager of your facility, please fill out and return the gold postcard.

If willing to participate, once the postcard has been returned:

2. You will then promptly receive a separate packet containing surveys and business reply envelopes for yourselves and those whom you directly supervise.

3. Distribute surveys.

4. Participants fill out the surveys and return them in the individual business reply envelopes provided. Surveys should take approximately 10 minutes to complete.

Please take a few minutes to fill out the postcard and return by October 17, 2003. The results of this study may shed light on aspects of management that have been largely unexamined. We appreciate your assistance and look forward to receiving your postcard.

Sincerely,

Anna Sarver

Graduate Student
Jennifer Oler, RD, CD

Graduate Student
Nora Nyland, PhD, RD, CD 


\section{Clinical Nutrition Manager Survey Participation Postcard}

Name:

Job Title:

Hospital:

\# Beds:

Work Address:

City:

Zip:

State:

Are you willing to participate in this survey?

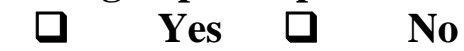

(If yes, subsequent mailings will be sent directly to you.)

How many of each of the following do you directly supervise?

a. Dietitians:

b. Diet Techs:

c. Other(s):

Thank you for your response. Please fill out and return this postcard by October 17, 2003. 
Appendix D

Pilot Study

-Director Pilot Cover Letter

-Clinical Nutrition Manager Pilot Cover Letter

-Director/Manager Pilot Questionnaire

-Employee Pilot Questionnaire 
NUTRITION, DIETETICS AND FOOD SCIENCE

BRIGHAM YOUNG UNIVERSITY

S-22I EYRING SCIENCE CENTER

PROVO, UTAH 84602-46O2

(8OI) 422-39I2/FAX: (8OI) 422-0258

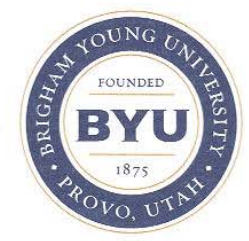

July 28,2003

$\diamond$

Dear $\diamond:$

Thank you for agreeing to participate in the pilot study for our research project on religiosity/spirituality and management in a healthcare setting.

Would you please assist us with the following:

- Read the initial cover letter and blue postcard. Note steps 1-4 on the initial cover letter. Follow these steps, but instead of sending back the postcard (as indicated in step 1), simply evaluate it on the green pilot questionnaire.

- For step two, we have included the packets for you and your clinical nutrition manager (if you have one at your facility). Please give the appropriately labeled packet to the clinical nutrition manager.

- Distribute blue employee surveys to three or four of those you supervise. (Step 3)

- Read the cover letter included with the packet labeled "Director of Food and Nutrition Services".

- $\quad$ Respond to the cream survey. (Step 4)

- Take a few additional minutes to answer the questions on the green pilot questionnaire about the letter and survey. Please ask your employees to fill out the yellow pilot questionnaire.

Once completed, you and your employees can return both the surveys and pilot questionnaires individually in the enclosed business reply envelopes by August 8, 2003.

Thank you for your assistance.

Sincerely,

Anna N. Sarver

Graduate Student
Jennifer S. Oler, RD, CD

Graduate Student
Nora Nyland, PhD, RD, CD 
July 28,2003

Dear Clinical Nutrition Manager:

Thank you for participating in the pilot study for our research project on religiosity/spirituality and management in a healthcare setting.

Would you please assist us with the following:

- Read the initial cover letter and gold postcard. Note steps 1-4 on the initial cover letter. Follow these steps, but instead of sending back the postcard (as indicated in step 1), simply evaluate it on the green pilot questionnaire.

- Distribute blue employee surveys to three or four of those you supervise. (Step 3)

- $\quad$ Read the cover letter included with the packet labeled "Clinical Nutrition Manager".

- $\quad$ Respond to the cream survey. (Step 4)

- $\quad$ Take a few additional minutes to answer the questions on the green pilot questionnaire about the letter, postcard, and survey. Please ask your employees to fill out the yellow pilot questionnaire.

Once completed, you and your employees can return both the surveys and pilot questionnaires individually in the enclosed business reply envelopes by August 8, 2003.

Thank you for your assistance.

Sincerely,

Anna N. Sarver

Graduate Student
Jennifer S. Oler, RD, CD

Graduate Student
Nora Nyland, PhD, RD, CD 


\section{Pilot Questionnaire}

Answer the questions about each of the following:

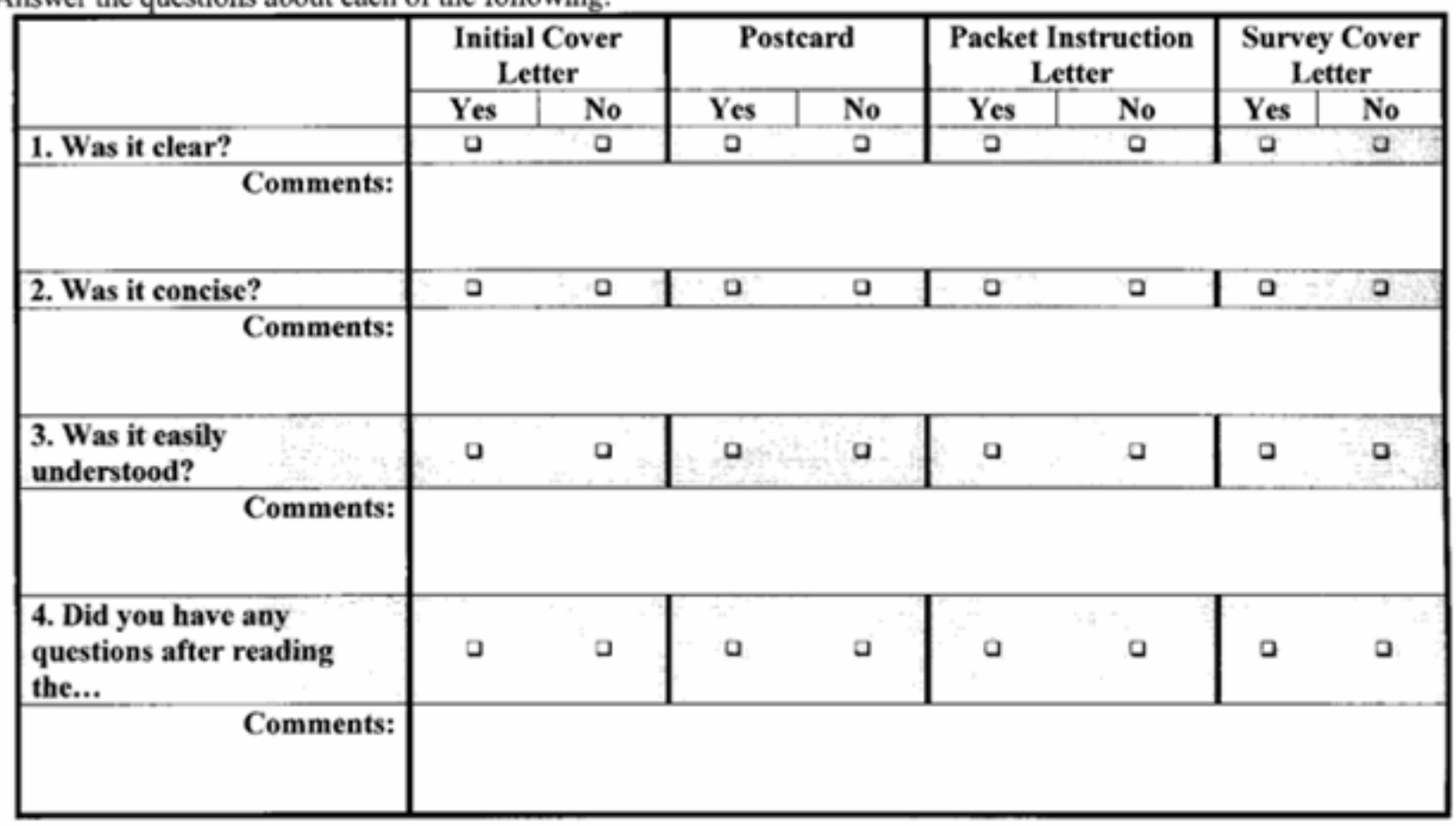

Answer the following questions about the survey.

1. Is the wording of any question confusing? $\square$ Yes $\square$ No

If yes, which question(s)?

2. Is the survey itself readable? $\square$ Yes $\square$ No

Comments

3. Are any questions offensive? $\square$ Yes $\square$ No

If yes, which question(s)?

4. Is the flow of questions logical? $\square$ Yes $\square$ No

Comments?

5. Are there any additional questions or issues that you feel should be addressed in the survey?

ㄱes $\mathrm{N}$ No Comments:

6. Approximately how long did it take for you to complete the survey?

7. Please give any other suggestions or comments: 


\section{Pilot Questionnaire}

Survey Cover Letter (front page of survey)

1. Was the cover letter:

Clear? $\square$ Yes $\square$ No

Comments

Concise? $\square$ Yes $\square$ No

Comments

Easily understood? $\square$ Yes $\square$ No

Comments

2. Did you have any questions after reading the survey cover letter? $\square$ Yes $\square$ No Comments

Answer the following questions about the survey.

1. Is the wording of any question confusing? $\square$ Yes $\square$ No

If yes, which question(s)?

8. Is the survey itself readable? $\square$ Yes $\square$ No

Comments

9. Are any questions offensive? $\square$ Yes $\square$ No

If yes, which question(s)?

10. Is the flow of questions logical? $\square$ Yes $\square$ No Comments?

11. Are there any additional questions or issues that you feel should be addressed in the survey? $\square$ Yes $\square$ No Comments:

12. Approximately how long did it take for you to complete the survey?

13. Please give any other suggestions or comments: 
Appendix E

Institutional Review Board Approval 
INSTITLTIONAL REVITW BOARD

November 12, 2003

Jennifer Oler

1576 N. Moonriver Dr. \#7

Provo, UT 84604

Dear Jennifer:

Thank you for your recent correspondence concerning your protocol entitled "Perception of Religiosity/Spirituality in Managers and Subordinates in Hospital Food and Nutrition Department." The research appears to pose minimal risk to human subjects and meets the Federal guidelines.

You are approved to begin your research. This approval is good for a maximum of one year, at which time, and sooner as need arises, the study will be reviewed again if the work is still in progress. Enclosed is a date stamped consent form. Please use this in obtaining consent. We will be sending a continuing review form before the expiration date. Please fill this form out in a timely manner to insure that there is not a lapse in your approval.

Please notify Nancy Davis, (801) 422-2970, A-261 ASB, of any changes made in the instruments, consent form, or research process before instigating the alterations, so that we can approve them.

If you have any questions, please let us know. We wish you well with your research!

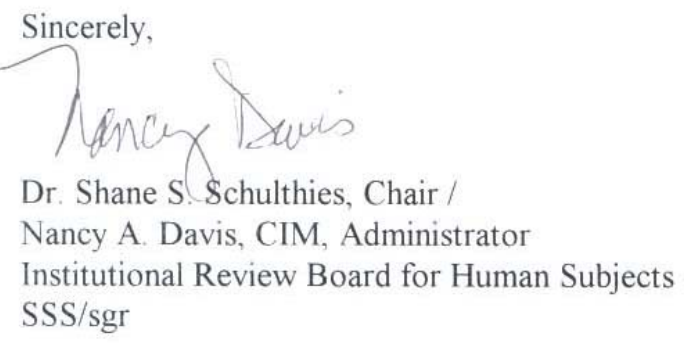

Dr. Shane S. Schulthies, Chair /

Nancy A. Davis, CIM, Administrator

Institutional Review Board for Human Subjects

SSS/sgr

Enclosure 
Appendix F

Survey Packets

\section{-Director Packet Letter}

-Clinical Nutrition Manager Packet Letter 
NUTRITION, DIETETICS AND FOOD SCIENCE

BRIGHAM YOUNG UNIVERSITY

S-22I EYRING SCIENCE CENTER

PROVO, UTAH 846O2-46O2

(8OI) 422-3912/FAX: (8OI) 422-0258

December 8, 2003

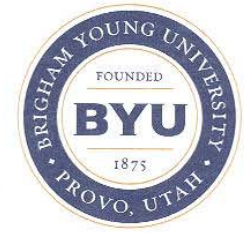

Dear $\diamond:$

Thank you for you willingness to participate in the religiosity/spirituality in management study we are conducting at Brigham Young University!

Enclosed you will find:

- One director/manager survey (cream) for you (if there is a clinical nutrition manager participating, a separate packet of surveys will be sent directly to him/her).

- Employee surveys (blue) for those whom you directly supervise [i.e. foodservice managers/supervisors, dietitians, and diet techs (who do not report to a clinical nutrition manager)]. Even though the clinical nutrition manager reports directly to you, he/she will not receive the blue employee survey from you.

- Postage-paid business reply envelopes for each individual survey.

Next:

- Complete the cream director/manager survey.

- Distribute the blue employee surveys with an envelope to those whom you directly supervise and ask for their participation.

- Upon completion, you and your employees can individually return the surveys in the postage-paid business reply envelopes by December 29, 2003.

Thank you for your support.

Sincerely,

Anna N. Sarver

Graduate Student
Jennifer S. Oler, RD, CD

Graduate Student
Nora Nyland, PhD, RD, CD 
NUTRITION, DIETETICS AND FOOD SCIENCE

BRIGHAM YOUNG UNIVERSITY

S-22I EYRING SCIENCE CENTER

PROVO, UTAH 84602-4602

(8OI) 422-39I2/FAX: (8OI) 422-O258

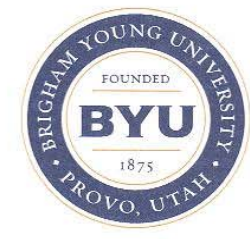

December 8, 2003

$\diamond$

Dear $\diamond$ :

Thank you for you willingness to participate in the religiosity/spirituality in management study we are conducting at Brigham Young University!

Enclosed you will find:

- One director/manager survey (cream) for you.

- Employee surveys (blue) for those whom you directly supervise (i.e. dietitians, diet techs, etc.) Even if you report directly to the Director of Food and Nutrition Services, you will not be completing the blue employee survey in relation to your director.

- Postage-paid business reply envelopes for each individual survey.

Next:

- Complete the cream director/manager survey.

- Distribute the blue employee surveys with an envelope to those whom you directly supervise and ask for their participation.

- Upon completion, you and your employees can individually return the surveys in the postage-paid business reply envelopes by December 29, 2003.

Thank you for your support.

Sincerely,

Anna N. Sarver

Graduate Student
Jennifer S. Oler, RD, CD

Graduate Student
Nora Nyland, PhD, RD, CD 
Appendix G

Cover Letters

-Director Cover Letter

-Employee Cover Letter 


\section{Religiosity/SPIRItuality AND WorkPlace PraCtices}

Fall 2003

Dear Director/Manager:

The professional relationship between supervisors and supervisees influences the workplace environment. Many aspects of this relationship have already been studied. A topic that has been increasingly studied is religiosity/spirituality in the workplace. We are investigating the impact of religiosity/spirituality on workplace relationships of foodservice and nutrition managers and those they supervise.

This study has been approved by the Institutional Review Board (IRB) at Brigham Young University. If you have questions about your rights as a participant, you may call Shane Schulthies, Chair of the IRB at (801) 422-5490. There are no known risks or discomforts associated with participation. Completion of the survey indicates your willingness to participate. The code number on the survey is for the use in data analysis. Only combined results will be reported; individual responses will be kept confidential.

The following pages include questions for you to respond to about yourself and those you directly supervise. The survey should take about 10 minutes to complete. Your participation is voluntary; however, in order to obtain data representative of Directors in Food and Nutrition Services, Clinical Nutrition Managers, and their subordinates, we need your participation. The results of this study may shed light on aspects of management that have been largely unexamined. Please complete this questionnaire and return it in the business reply envelope within the next three weeks.

We appreciate your assistance!

Sincerely,

Anna Sarver Jennifer Oler, RD, CD Nora Nyland, PhD, RD, CD

Graduate Student

Graduate Student

DEPARTMENT OF NUTRITION, DIETETICS, AND FOOD SCIENCE

BRIGHAM YoUNG UNIVERSITY • S221 EYRING SCIENCE CENTER • PROVO, UTAH 84602-4602

(801)422-3912/FAX (801)422-0258•workplacesurvey@byu.edu 


\section{Religiosity/SPIRITUAlity AND WorkPlace PRACTICES}

Fall 2003

Dear Foodservice/Clinical Nutrition Team Member:

The professional relationship between supervisors and supervisees influences the workplace environment. Many aspects of this relationship have already been studied. A topic that has been increasingly studied is religiosity/spirituality in the workplace. We are investigating the impact of religiosity/spirituality on workplace relationships of foodservice and nutrition employees and their director/managers. Your hospital has been selected for participation in this study from the American Hospital Association database.

This study has been approved by the Institutional Review Board (IRB) at Brigham Young University. If you have questions about your rights as a participant, you may call Shane Schulthies, Chair of the IRB at (801) 422-5490. There are no known risks or discomforts associated with participation. Completion of the survey indicates your willingness to participate. The code number on the survey is for the use in data analysis. Only combined results will be reported; individual responses will be kept confidential.

The following pages include questions for you to respond to about yourself and your director/manager. The survey should take about 10 minutes to complete. Your participation is voluntary; however, in order to obtain data representative of foodservice and nutrition employees and their directors/managers, we need your participation. The results of this study may shed light on aspects of workplace practices that have been largely unexamined. Please complete this questionnaire and return it in the business reply envelope within the next three weeks.

We appreciate your assistance!

Sincerely,

Anna Sarver Jennifer Oler, $\mathrm{RD}, \mathrm{CD}$

Nora Nyland, PhD, RD, CD

Graduate Student

Graduate Student 
Appendix H

Follow-Up \#1

-Form A

-Form B 
NUTRITION, DIETETICS AND FOOD SCIENCE

BRIGHAM YOUNG UNIVERSITY

S-22I EYRING SCIENCE CENTER

PROVO, UTAH $84602-4602$

(8OI) 422-39I2/FAX: (8OI) 422-O258

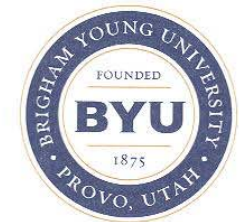

December 1, 2003

$\diamond$

Dear $\diamond$ :

Thank you for your participation in the religiosity/spirituality in management study. We recently received your director/manager cream survey and appreciate your assistance. However, we are still missing some of the employee surveys from those you directly supervise. If they have sent the surveys, we extend our thanks, and ask that you disregard this letter.

If your direct subordinates have not yet responded, please remind and encourage them to take the time to complete and return the blue employee survey in the postage-paid business reply envelope by December 17, 2003. The surveys should take about ten minutes.

If the surveys have been misplaced or additional copies are needed, please feel free to contact us through email at workplacesurvey@byu.edu or by phone at 801-422-6676. Include the type (director/manager vs. employee) and number of surveys needed, and the surveys and additional business reply envelopes will be sent directly.

Because this survey is looking at the views and feelings of both directors/managers and their direct subordinates, participation by both groups is important to us. We appreciate your assistance and the assistance of your direct subordinates.

Sincerely,

Anna N. Sarver

Graduate Student
Jennifer S. Oler, RD, CD

Graduate Student
Nora Nyland, $\mathrm{PhD}, \mathrm{RD}, \mathrm{CD}$ 
NUTRITION, DIETETICS AND FOOD SCIENCE

BRIGHAM YOUNG UNIVERSITY

S-22I EYRING SCIENCE CENTER

PROVO, UTAH $84602-4602$

(8O1) 422-3912/FAX: (8OI) 422-0258

December 1, 2003

$>$

Dear $>$ :

Recently we sent you a packet containing surveys for the religiosity/spirituality in management study. This packet should have contained a director/manager survey (cream) for yourself and employee surveys (blue) for those you directly supervise. So far we have had a good response rate. But, to date, we have not received surveys from yourself and/or your direct subordinates. If you and your subordinates have sent the surveys, we extend our thanks, and ask that you disregard this letter.

If you have not yet responded, we request that you complete the cream director/manager survey and distribute the blue employee surveys (with the included envelopes) to those whom you directly supervise and ask for their participation. The surveys should take about ten minutes, and upon completion, we ask that you and your employees individually return the surveys in the postage-paid reply envelope by December $\mathbf{1 7 , 2 0 0 3}$. If you have already distributed the employee surveys, please encourage your employees to take the time to complete and return the survey soon.

If you have misplaced the surveys or need additional copies for yourself or employees, please feel free to contact us through email at workplacesurvey@byu.edu or by phone at 801-422-6676. Include the type (director/manager vs. employee) and number of surveys needed, and the surveys and additional business reply envelopes will be sent directly.

Because this survey is looking at the views and feelings of both directors/managers and their direct subordinates, participation by both groups is important to us. We appreciate your assistance.

Sincerely,

Anna N. Sarver

Graduate Student
Jennifer S. Oler, RD, CD

Graduate Student
Nora Nyland, PhD, RD, CD 
Appendix I

Follow-Up \#2

-Group 1: Director Letter

-Group 1: Employee Letter -Group 2: Director Letter

-Group 2: Employee Letter -Group \#3: Director Memo 
NUTRITION, DIETETICS AND FOOD SCIENCE

BRIGHAM YOUNG UNIVERSITY

S-221 EYRING SCIENCE CENTER

PROVO, UTAH 84602-4602

(8OI) 422-3912/FAX: (8OI) 422-0258

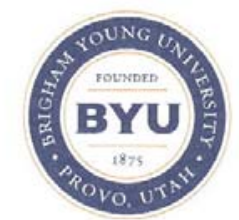

January 16,2004

$\diamond$

Dear $\diamond:$

Thank you for your participation in the religiosity/spirituality in management study. We are excited about the good response rate we have received thus far. However, to effectively include all the data, we need a director/manager survey and at least one employee survey from each participating group. To date, our records show we have received your director/manager survey and thank you for your participation. However, we have not received any employee surveys from your facility.

We realize that you have probably already distributed the first mailing of the blue employee surveys to those you directly supervise and we thank you for your assistance. However, we request your assistance one more time in being the liaison between us and your employees as we have no way of directly contacting them. We have included letters to your employees and additional copies of the blue employee survey, and ask that you pass these on to those you directly supervise. We know that response is voluntary, but please encourage your employees to take about ten minutes to complete the survey and then return it as soon as possible in the provided postage-paid business reply envelopes.

If additional copies of the survey are needed or you have further questions regarding this study, please feel free to contact us through email at workplacesurvey@byu.edu or by phone at 801-422-6676.

Because the topic of this survey considers the views and feelings of both directors/managers and their direct subordinates, individual participation is important to us. We appreciate your assistance in delivering the included letter and surveys to your direct subordinate, and look forward to their response.

Sincerely,

Anna N. Sarver

Graduate Student
Jennifer S. Oler, RD, CD

Graduate Student
Nora Nyland, PhD, RD, CD 
NUTRITION, DIETETICS AND FOOD SCIENCE

BRIGHAM YOUNG UNIVERSITY

S-22I EYRING SCIENCE CENTER

PROVO, UTAH $84602-4602$

(8OI) 422-3912 / FAX: (8OI) 422-0258

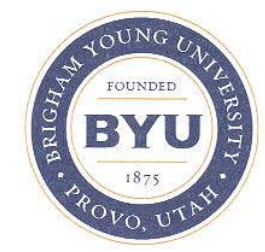

January 16, 2004

Dear Foodservice/Clinical Nutrition Team Member:

This past fall, we sent your manager a packet containing surveys for a study investigating religiosity/spirituality in the workplace and impact on leader/follower relationships. We are excited about the good response rate we have received thus far. However to effectively include all the data, we need at least one employee survey and a director/manager survey from each participating group. To date, our records show we have not received any employee surveys from your facility. If you have sent the survey, we extend our thanks, and ask that you disregard this letter.

If you have not yet responded or if this is your first time seeing the survey, we request your participation in completing the enclosed blue employee survey. Your response is, of course, voluntary, but we ask that you take about ten minutes to complete and return the survey in the provided postage-paid business reply envelopes as soon as possible.

If you have further questions regarding this study, please feel free to contact us through email at workplacesurvey@byu.edu or by phone at 801-422-6676.

Because the topic of this survey considers the views and feelings of both directors/ managers and their team members, individual participation is important to us. We appreciate your assistance, and look forward to your response.

Sincerely,

Anna N. Sarver

Graduate Student
Jennifer S. Oler, RD, CD

Graduate Student
Nora Nyland, $\mathrm{PhD}, \mathrm{RD}, \mathrm{CD}$ 
Recently we sent you a packet containing surveys for the religiosity/spirituality in management study. We are excited about the good response rate we have received thus far. However to effectively include all the data, we need a director/manager survey and at least one employee survey from each participating group. To date, our records show we have received at least one employee survey from your facility, but we are still missing your director/manager survey and some of the employee surveys. If you have recently sent the director/manager survey, we extend our thanks.

If you have not yet responded, we again request your participation and have enclosed an additional copy of the cream director/manager survey. Please take about ten minutes to complete and return the survey in the provided postage-paid business reply envelope as soon as possible.

We realize that you already distributed the first mailing of blue employee surveys to those you directly supervise, and we thank you for your help. However, we request your assistance one more time in being the liaison between us and your employees as we have no way of directly contacting them. We have included letters to your employees and additional copies of the blue employee survey, and ask that you pass these on to those you directly supervise. We know that response is voluntary, but please encourage your employees to take about ten minutes to complete the survey and then return it as soon as possible in the provided postage-paid business reply envelopes.

If additional copies of the survey are needed or you have further questions regarding this study, please feel free to contact us through email atworkplacesurvey@byu.edu or by phone at 801-422-6676.

Because the topic of this survey considers the views and feelings of both directors/ managers and their direct subordinates, individual participation is important to us. We appreciate your assistance, and look forward to your response.

Sincerely,

Anna N. Sarver

Graduate Student
Jennifer S. Oler, RD, CD

Graduate Student
Nora Nyland, $\mathrm{PhD}, \mathrm{RD}, \mathrm{CD}$ 
NUTRITION, DIETETICS AND FOOD SCIENCE

BRIGHAM YOUNG UNIVERSITY

S-22I EYRING SCIENCE CENTER

PROVO, UTAH 846O2-46O2

(8OI) 422-39I2/FAX: (8OI) 422-0258

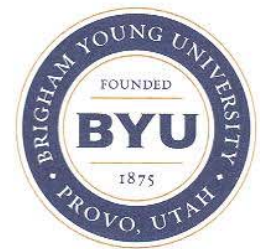

January 16, 2003

Dear Foodservice/Clinical Nutrition Team Member:

This past fall, we sent your manager a packet containing surveys for a study investigating religiosity/spirituality in the workplace and impact on leader/follower relationships. We are excited about the good response rate we have received thus far. However to effectively include all the data, we need both employee and director/manager surveys from each participating group. To date, our records show we are still missing some of the employee surveys from your facility. If you have sent the survey, we extend our thanks, and ask that you disregard this letter.

If you have not yet responded or if this is your first time seeing the survey, we request your participation in completing the enclosed blue employee survey. Your response is, of course, voluntary, but we ask that you take about ten minutes to complete and return the survey in the provided postage-paid business reply envelopes as soon as possible.

If you have further questions regarding this study, please feel free to contact us through email at workplacesurvey@byu.edu or by phone at 801-422-6676.

Because the topic of this survey considers the views and feelings of both directors/ managers and their team members, individual participation is important to us. We appreciate your assistance, and look forward to your response.

Sincerely,

Anna N. Sarver

Graduate Student
Jennifer S. Oler, RD, CD

Graduate Student
Nora Nyland, PhD, RD, CD 


\section{Memo}

\section{BYU}

To: Foodservice or Clinical Nutrition Director

From:Jennifer Oler and Anna Sarver

Date: January 22, 2004

Re: Religiosity/Spirituality in Management Study

Last fall you should have received a packet containing a director survey and several employee surveys in response to your willingness to participate in our religiosity/spirituality in management study. To date, our records show we have not yet received any surveys from your facility.

It is not too late! We have had great response, but would also like to include your facility and would appreciate your response to our questionnaire. If you are still willing to participate, please reply to this email. We just need the name of your hospital and we will send replacement surveys immediately.

Sincerely,

Anna N. Sarver

Graduate Student

Jennifer S. Oler, RD, CD

Graduate Student

Nora Nyland, $\mathrm{PhD}, \mathrm{RD}, \mathrm{CD}$

DEPARTMENT OF NUTRITION, DIETETICS, AND FOOD SCIENCE

BRIGHAM YOUNG UNIVERSITY • S221 EYRING SCIENCE CENTER • PROVO, UTAH 84602-4602

(801) 422-6676/FAX (801)422-0258•workplacesurvey@byu.edu 
Appendix $\mathbf{J}$

Follow-Up \#3 
NUTRITION, DIETETICS AND FOOD SCIENCE

BRIGHAM YOUNG UNIVERSITY

S-22I EYRING SCIENCE CENTER

PROVO, UTAH 84602-4602

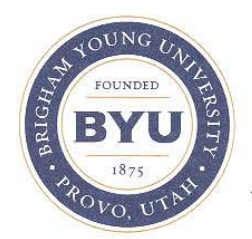

(8OI) 422-39I2/FAX: (8OI) 422-O258

February 6, 2004

$<$

Dear $\diamond$ :

\begin{abstract}
Roses are red
Violets are blue

If you fill out this survey

We'll stop bugging you!
\end{abstract}

We wanted to thank you so much for your help in distributing the surveys for the religiosity/spirituality in management study to your employees. We have been excited about the number of responses we have received. To date, we have received at least one employee survey from your facility, but we are still missing your director/manager survey. If you have recently sent the director/manager survey, we extend our thanks.

If you have not yet responded, we again request your participation and have enclosed a copy of the cream director/manager survey. Please take a few minutes to complete and return the survey in the provided postage-paid business reply envelope as soon as possible.

If you have any questions regarding this study, please feel free to contact us through email at workplacesurvey@byu.edu or by phone at 801-422-6676.

We realize that you are a busy professional and really appreciate you taking the time to assist us in our research. Happy Valentine's Day!

Sincerely,

Anna N. Sarver

Graduate Student
Jennifer S. Oler, RD, CD

Graduate Student
Nora Nyland, PhD, RD, CD 